\title{
Can high intensity interval training improve mental health outcomes in the general population and those with physical illnesses? A systematic review and meta-analysis of 53 randomized controlled trials
}

Running heading: High Intensity Interval Training for Mental Health

Rebecca Martland $^{\mathrm{a} b *}$; Nicole Korman ${ }^{\mathrm{c}} \mathrm{de}$; Joseph Firth ${ }^{\mathrm{fgh}}$; Davy Vancampfort ${ }^{\mathrm{ijk}}$; Trevor Thompson ${ }^{\mathrm{Im}}$; Brendon Stubbs ano

${ }^{a}$ King's College London, London, Institute of Psychiatry, Psychology and Neuroscience (IOPPN), United Kingdom

${ }^{b}$ ORCID 0000-0002-4080-0171

${ }^{c}$ Metro South Addiction and Mental Health Services, Brisbane, Australia

${ }^{d}$ University of Queensland, School of Medicine, Brisbane, Australia

e ORCID 0000-0003-1414-1050

${ }^{f}$ University of Manchester, Manchester, Faculty of Biology, Medicine \& Health, Division of Psychology and Mental Health, United Kingdom

${ }^{g}$ Western Sydney University, Westmead, NSW, NICM Health Research Institute, Australia

${ }^{h}$ ORCID 0000-0002-0618-2752

${ }^{i}$ KU Leuven Department of Rehabilitation Sciences, Leuven, Belgium

j University Psychiatric Centre KU Leuven, Kortenberg, Belgium

k Orcid 0000-0002-4592-8625

' University of Greenwich, London, School of Human Sciences, United Kingdom 
${ }^{m}$ Orcid 0000-0001-9880-782X

${ }^{n}$ South London and Maudsley NHS Foundation Trust, Denmark Hill, London, SE5 8AZ, United Kingdom

o Orcid 0000-0001-7387-3791

*Corresponding author at: Rebecca Martland, Department of Psychosis Studies, Institute of Psychiatry, Psychology and Neuroscience (IOPPN), King's College London, London, United Kingdom

Email address: rebecca.martland@kcl.ac.uk, Telephone number: [+44] 07551988500

Word count (excluding abstract, references, figures/tables): 4677 words

\section{ABSTRACT}

Objective- High-intensity interval training (HIIT) is a safe, feasible and time-efficient form of exercise. The aim of this systematic review was to investigate the mental health effects of HIIT, in healthy populations and those with physical illnesses, and to compare the mental health effects to both nonactive controls and other forms of exercise.

Design- Random effects meta-analyses were undertaken for randomized controlled trials (RCTs) comparing HIIT with non-active (non-exercise) and/or active (exercise) control conditions for the following co-primary outcomes: mental wellbeing, depression, anxiety and psychological stress, calculating the standardized mean difference (SMD) and 95\% confidence interval $(\mathrm{Cl})$. Positive and negative affect, distress and sleep outcomes were summarised narratively.

Data Sources- Medline, PsycINFO and Embase were searched from inception to 07.07.2020.

Eligibility criteria for selecting studies- RCTs that investigated HIIT in healthy populations and/or those with physical illnesses and reported change in mental wellbeing, depression, anxiety, psychological stress, positive and negative affect, distress and/or sleep quality.

Results- Fifty-three RCTs were retrieved. HIIT led to moderate improvements in mental wellbeing $(\mathrm{SMD}=0.427,95 \% \mathrm{Cl}=0.124 ; 0.730)$, depression severity $(\mathrm{SMD}=-0.496,95 \% \mathrm{Cl}=-0.973 ;-0.020)$ and perceived stress $(\mathrm{SMD}=-0.474,95 \% \mathrm{Cl}=-0.796 ;-0.152)$ compared to non-active controls, and small improvements in mental wellbeing compared to active controls ( $S M D=0.272,95 \% \mathrm{Cl}=0.088 ; 0.456)$. There was a suggestion that HIIT may improve sleep and psychological distress compared to non-active controls, however these findings were based on a small number of RCTs.

Conclusion- These findings support the use of HIIT for mental health in the general population and those with physical illnesses.

Registration: Prospero (CRD42020182643) 
Key words: High intensity interval training; meta-analysis; mental health; mental wellbeing; depression; anxiety

\section{What is already known?}

High intensity interval training (HIIT) is a potential safe, feasible and time-efficient form of exercise.

Preliminary research suggests that HIIT can improve mental health in people with mental health disorders.

The mental health benefits associated with HIIT, in healthy populations and those with physical illnesses, are unclear.

No meta-analysis has been performed thus far on research examining potential effects of HIIT on mental health in healthy populations and those with physical illnesses.

\section{What are the new findings?}

HIIT leads to moderate improvements in mental wellbeing, depression severity and perceived stress compared to no exercise.

In healthy populations and those with physical illnesses, HIIT leads to small improvements in mental wellbeing compared to other forms of exercise.

HIIT appears to be a useful intervention to target mental health. 


\section{INTRODUCTION}

Physical activity, and its structured form exercise, have been shown to improve mental wellbeing and reduce the symptoms of depression and anxiety, across epidemiological studies and interventions, across a wide range of populations,[1-4]. These benefits have been observed in healthy men and women,[5], older adults,[6], adolescents,[7], people with neurological disorders, [8] and patients with chronic illnesses (e.g., cardiometabolic diseases, chronic pain, cancer and chronic obstructive pulmonary disease (COPD)),[9-11]. Moreover, preliminary research suggests a role of exercise in reducing perceived psychological distress,[12-15], and improving sleep quality,[16-18]. Additionally, a single bout of exercise may improve psychological well-being in the short-term, $[19,20]$.

The majority of high-quality reviews have assessed the effects of traditional forms of exercise such as moderate intensity continuous training (MICT), walking and functional exercises. High-intensity interval training (HIIT) is gaining recognition as a safe and feasible form of exercise that may elicit gains in physical health in less time than traditional forms of exercise, in the general population and those with chronic conditions,[21]. HIIT involves alternating short bursts (commonly 30 seconds to 4 minutes) of high intensity exercise, that typically reaches $\geq 85 \%$ peak heart rate (HRpeak), followed by similar length recovery periods of rest/ light exercise typically carried out at $\leq 70 \%$ HRpeak,[22]. Two recent metaanalyses found encouraging evidence for the benefit of HIIT in improving mental health outcomes in people with mental disorders, $[23,24]$. Multiple trials in other people, such as healthy populations and those with physical illnesses, have investigated the effect of HIIT on mental health outcomes including mental wellbeing, $[25,26]$, depressive and anxiety symptoms, $[27,28]$, and sleep quality,[29] and have inconsistent findings. The lack of consistency in the literature is hampered by small sample sizes, and differences in HIIT protocols and participant characteristics.

The aim of this systematic review and meta-analysis was to investigate the mental health effects of HIIT in healthy populations and those with physical illnesses drawing evidence from randomised controlled trials (RCTs) of any type of HIIT exercise investigating mental wellbeing, depression, anxiety, stress and/or sleep disturbance, and to compare the mental health effects to both non-active controls and other forms of exercise. The secondary aim of this systematic review was to report the safety, adherence and design of the included HIIT interventions to aid translation into clinical practice.

\section{METHODS}

The systematic review and meta-analysis were performed in accordance with the PRISMA guidelines following a pre-determined published protocol (Prospero CRD42020182643). (PRISMA checklist= Appendix 1). 


\section{Definition of high intensity interval training}

HIIT was defined as alternating short bursts of high intensity exercise, that reached $\geq 85 \%$ HRpeak/ $\geq 80 \%$ peak $\mathrm{VO}_{2}$, or equivalent measure, interspersed with recovery periods of $\leq 5$ minutes in duration whereby a reduction in intensity was described,[22]. We included any form of exercise (treadmill, cycling, boxing, body-weight exercises).

\section{Searches and study selection}

Medline, PsycINFO and Embase were searched from inception to 07.07.2020 for RCTs investigating HIIT among healthy individuals and people with any physical health diagnosis (cardiometabolic diseases, COPD, cancer). To avoid repetition of published work, $[23,24]$ RCTs investigating HIIT in populations with a structured mental health diagnosis were excluded.

The search terms used are found in Appendix 2. The reference lists of included articles were handsearched.

\section{Eligibility criteria}

Three authors (RM, BS, NK) independently assessed articles based on the following eligibility criteria: 1) RCTs investigating HIIT, in any setting and age. We considered any form of control group including no treatment, therapeutic and lifestyle interventions, other exercise interventions except HIIT; 2) HIIT interventions of any duration and frequency, including follow-up studies; 3) a study population which included any human population including those with physical illnesses and excluding those with a structured mental health diagnosis (severe mental illnesses, substance and alcohol disorders, anxiety and stress disorders, eating disorders). Non-English language articles, conference abstracts and dissertation theses were excluded.

\section{Outcomes}

Primary outcomes

Changes in mental health parameters including: 1) mental wellbeing; 2) depressive symptoms; 3) anxiety; 4) psychological stress; 5) positive and negative affect; 6) distress; 7) insomnia and/or sleep quality.

\section{Secondary outcomes}

Adverse events (AEs) and completion rates.

\section{Search results and data extraction}

The title and abstract of all studies identified were reviewed, and relevant full-texts reviewed to determine eligibility. Eligibility was determined by three independent researchers (RM, BS, NK).

Data was extracted, from the papers selected for inclusion in the review, by one researcher (RM) and verified by a second researcher (BS). For each study, we reported: study design, sample size, participant demographics, intervention descriptions (including control interventions), effect sizes (ES); adherence; and any AEs.

Where an RCT was retrieved that measured mental health outcomes but did not provide the relevant statistics the authors were emailed to request the relevant data. Mental health outcomes measured as 
part of a disease-specific quality of life scale (e.g., Depression measured as part of the Parkinson's Disease Questionnaire-39) were excluded. Measures of sport related anxiety and stress were excluded.

\section{Quality Assessment}

The quality of the included RCTs were assessed using the Physiotherapy Evidence Base Database (PEDro) scale [30]. Scores were taken from the PEDro database (http://www.PEDro.org.au) where available. When a score was not already determined on the database for a study, it was generated by two independent researchers (RM and NK) (Appendix 3). High, fair and poor-quality studies achieved ratings of 8-10; 4-7 and $1-3$ respectively.

Additionally, for each RCT, data regarding the intervention description was reported using the Consensus on Exercise Reporting Template (CERT),[31] to ensure complete reporting. This information was tabulated and is provided in Appendix 4.

\section{Data synthesis}

Between group meta-analyses were conducted when at least three RCTs were retrieved for each outcome. We conducted between group meta-analyses for RCTs comparing HIIT with non-active (nonexercise) and/or active (exercise) control conditions for the following outcomes: mental wellbeing, depression, anxiety and psychological stress (as measured via the Perceived Stress Scale,[32]). Separate meta-analyses were conducted comparing HIIT versus non-active and active controls on mental wellbeing using data retrieved from the SF-36,[33]. For this analysis, we included studies that provided a norm-based MCS score. When a raw data MCS score was provided the individual subdomains of the SF-36 were sought and a norm-based MCS score was calculated using z-score transformations and the relevant population means,[34]. In these instances, the standard deviation (SD) was imputed as 10; based on population data in the original SF-36 user manual,[34]. Due to variation in HIIT protocols and participant characteristics, we used a random-effects model calculating the standardised mean difference (SMD) and 95\% confidence intervals $(95 \% \mathrm{Cl})$ using the difference between the two groups' pre-post change scores. Cohen's criteria were used as a benchmark for interpreting effect size (0.2 small, 0.5 medium, 0.8 large),[35]. Heterogeneity was assessed using the $\mathrm{I}^{2}$ statistic. Publication bias was assessed with the Begg-Mazumdar Kendall's tau,[36] and Egger bias test,[37]. In addition, we conducted a trim and fill adjusted analysis,[38] to remove the most extreme small studies from the positive side of the funnel plot, and recalculated the ES at each iteration, until the funnel plot was symmetric about the (new) ES.

When an RCT was encountered that had two arms conducting HIIT (of different intensities/modalities) only one HIIT arm was included in the main meta-analysis to prevent replication of control conditions. In these instances, the HIIT regime that was most similar to other included RCTs was included in the main meta-analysis- a full explanation is in Appendix 5. For each of the primary outcomes, subgroup analysis for HIIT modality, HIIT intervention duration and frequency, and population characteristics were conducted were sufficient RCTs were available (Table 4). A sensitivity analysis was not conducted as all included studies received a PEDro rating of $\geq 4$.

Positive and negative affect, psychological distress (measures of emotional disturbances) and sleep outcomes were summarised narratively due to variability in outcome measurement tools and paucity of retrieved RCTs. 
Similarly, studies investigating the acute mental health effects of a single bout of HIIT were not included in the meta-analysis and were summarised narratively due to variability in mental health outcomes measured and paucity of retrieved RCTs. Follow-up data was also analysed in a narrative synthesis with effect size and/or significance level reported.

\section{RESULTS}

\section{Search results and included studies}

Search results are in Figure 1. Overall, 53 RCTs $(n=2,901)$ were included (including three follow-up analyses,[39-41]) encompassing HIIT in adults with no medical comorbidities ( $N=10, n=577),[28,29,42-$ 49], healthy older adults $(N=3, n=142,[50-52]$, adolescents $(N=2, n=133),[26,53]$, patients with cardiometabolic disorders (including obesity, hypertension, diabetes, metabolic syndrome (MetS), heart failure, coronary artery disease (CAD)) ( $N=29, n=1599),[25,27,59-68,39,69-77,40,41,54-58]$, COPD ( $N=3$, $n=193),[78-80]$, cancer-patients $(N=2, n=78),[81,82]$, patients with Lacunar stroke $(N=1, n=71),[83]$, Crohn's disease $(N=1, n=36),[84]$, cutaneous systemic sclerosis (SSc) ( $N=1, n=34),[85]$ and patients undergoing liver resection $(\mathrm{N}=1, \mathrm{n}=38),[86]$ (see Fig 1 ). Mean age of participants ranged from 15.5-74.9 years.

\section{Figure One- PRISMA flow-chart}

[insert figure here]

The duration of the HIIT programme ranged from a single session to 10 months and $64 \%$ of programmes were conducted for 8-12 weeks. HIIT was conducted 1-5 times per week and session length ranged from 10-71 minutes. Fifty-five percent of RCTs prescribed cycling HIIT, 15\% prescribed running HIIT, and other modalities included boxing, suspension training, resistance training and mixed-modality sports. Twentyone RCTs compared HIIT to an active (exercise) control, $[25,39,60,62,66,67,70,72,73,77-$ $79,40,80,47,48,51,54-56,59], 22$ RCTs compared HIIT to a non-active control,[26,27,63$65,68,69,71,75,81-83,28,85,86,41,43,44,49,52,53,61]$, 9 RCTs compared HIIT to both active and nonactive conditions,[29,42,45,46,50,58,74,76,84], and one RCT compared HIIT to a low-energy diet,[57]. Where an active control group was prescribed, continuous cycling or jogging was provided on twentyfive occasions (83\%). Four studies measured the acute effects of HIIT before and after individual sessions, $[45,47,55,78]$, one study measured both acute and chronic mental health effects, [48] and the remaining studies measured the chronic mental health effects of HIIT.

Tables 1 and 2 respectively compile information on intervention details, and mental health findings. Full meta-analysis results are displayed in Tables 3-4.

\section{Quality of included studies and exercise reporting}

PEDRO scores are summarised in Appendix 3. 
Total score ranged from $4,[28,41,42,51,55,61,63,71,74]$ to $8,[52,70,77,80,84]$, the mean score was 5.7. Allocation was concealed in $64.2 \%$ of RCTs, all RCTs ensured groups were similar at baseline and $39.6 \%$ blinded assessors. All studies provided measures of variability of key outcomes, $62.3 \%$ provided measures of key outcome for $\geq 85 \%$ of subjects initially recruited and $30.2 \%$ analysed results on an intention-to-treat (ITT) basis.

$50 / 53$ (94\%) of RCTs reported the materials used in sufficient detail to allow accurate replication, three RCTs $(8 \%)$ did not, $[40,54,62]$ (these trials did not divulge into detail regarding exercise modality). Supervision was provided in 51 RCTs (96\%), one RCT conducted non-supervised home-based HIIT,[83] and one did not provide supervision details,[62]. Additionally, in five RCTs participants were asked to conduct extra non-supervised HIIT sessions/supplementary home-based components, $[27,53,65,67,70]$. HIIT was mostly supervised by a researcher, physiotherapist or personal trainer, although background of the supervisor was not reported in 16 RCTs (30\%). Twelve (23\%) RCTs conducted HIIT in group settings, eight RCTs (15\%) conducted 1:1 sessions, one RCT (2\%) gave participants the choice of a group or individual session and 31 RCTs (58\%) did not report delivery method of their supervised sessions. All RCTs HIIT intensity to each individual's HRpeak/VO2max/VO2peak/maximal capacity. Where reported, motivational strategies included positive encouragement,[40,54,55,74], motivational talks and fitness advice,[60,61,83], monetary compensation/gift vouchers,[26,42,63], free gym memberships,[42], Fitbits,[42], and certificates,[26]. It is also important to note that actual intensity reached during HIIT sessions was reported in 31 RCTs (58\%), of which 26 (49\%) stated that, on average, the desired heart rate ( $\geq 85 \%$ HRpeak/equivalent) was reached during high intensity bursts as per protocol, $[26,28,64,66-$ $72,74,77,39,79-82,84,85,41,44,46,49,52,53,62]$, and five RCTs (9\%) reported that either a lower intensity was averaged/a proportion of participants did not meet the desired intensity, $[40,45,54,75,78]$, whereas 22 RCTs (42\%) offered no discussion as to whether the HIIT protocol was adhered to, $[25,27,56-$ $61,63,65,73,76,29,83,86,42,43,47,48,50,51,55]$.

\title{
Mental wellbeing
}

HIIT resulted in a moderate increase in MCS scores compared to non-active control $(S M D=0.427$, $\left.95 \% \mathrm{Cl}=0.124 ; 0.730, \mathrm{p}=0.006, \mathrm{Q}=25.683, \mathrm{I}^{2}=61.064 \%, \mathrm{~N}=11\right)$, and no evidence of publication bias, $[50,52,81,58,61,63-65,74-76]$. In subgroup analysis, HIIT regimes of duration $\geq 7$ weeks significantly increased MCS scores compared to non-active control ( $S M D=0.580,95 \% \mathrm{Cl}=0.330 ; 0.830$ ), whereas those of duration $<7$ weeks did not $(S M D=-0.264,95 \% \mathrm{Cl}=-0.745 ; 0.217)$.

HIIT resulted in a small increase in MCS scores compared to active control (SMD=0.272, 95\% $\mathrm{Cl}=0.088$; $\left.0.456,1^{2}=0 \%, N=10\right)$, and no evidence of publication bias,[50,54,58,67,72-74,76,77,79]. Subgroup analyses revealed no effects of HIIT regime and population characteristics on change in MCS score compared to active control.

\section{Figure Two- Meta-analysis of changes in MCS score for HIIT versus non-active controls}

\author{
[insert figure here]
}




\section{Depression}

HIIT resulted in a moderate reduction in depression severity compared to non-active control, with high heterogeneity $\left(S M D=-0.496,95 \% C l=-0.973 ;-0.020, I^{2}=82.138 \%, N=10\right),[27,28,42,43,61,63,81-84]$. There was no evidence of publication bias and subgroup analyses revealed no significant effects of HIIT regime and population characteristics.

Following HIIT, no reduction in depression severity compared to active control was found (SMD $=-0.110$, $\left.95 \% \mathrm{Cl}=-0.310 ; 0.091, \mathrm{I}^{2}=0 \%, \mathrm{~N}=9\right),[42,54,56,60,62,70,79,80,84]$.

\section{Anxiety}

Following HIIT, no reduction in anxiety severity compared to both non-active and active controls was found $\left(\mathrm{SMD}=-0.289,95 \% \mathrm{Cl}=-0.700 ; 0.121, \mathrm{I}^{2}=71.922 \%, \mathrm{~N}=8,[54,56,60,62,79,80]\right.$; $\mathrm{SMD}=-0.302,95 \% \mathrm{Cl}=-$ $0.732 ; 0.128, I^{2}=71.922 \%, N=8,[28,43,44,61,63,81,82,84]$, respectively).

\section{Psychological Stress}

HIIT resulted in a moderate decrease in perceived stress compared to non-active control (SMD $=-0.474$, $\left.95 \% \mathrm{Cl}=-0.796 ;-0.152, \mathrm{I}^{2}=20.432 \%, \mathrm{~N}=4\right)$, no evidence of publication bias was found, $[42,44,53,81]$. In subgroup analysis, HIIT regimes of frequency $\geq$ twice weekly significantly reduced perceived stress compared to non-active control (SMD $=-0.574,95 \% \mathrm{Cl}=-0.877 ;-0.252)$, whereas those of frequency $<$ twice weekly did not (SMD= $-0.554,95 \% \mathrm{Cl}=-0.896 ; 0.344)$. HIIT regimes significantly reduced perceived stress, in healthy populations, compared to non-active control ( $S M D=-0.474,95 \% \mathrm{Cl}=-0.696 ;-0.256$ ), whereas those in people with physical illnesses did not (SMD $=-0.371,95 \% \mathrm{Cl}=-0.654 ; 0.199)$.

One RCT compared HIIT to an active control condition,[42]. Following 12-weeks of HIIT there was no change in perceived stress compared to continuous aerobic exercise (CA),[42].

\section{Positive and Negative Affect}

Two RCTs, $[48,69]$ observed no change in positive and negative affect following HIIT regimes of duration 10-12 weeks, compared to MICT, although significant within-group improvements in positive and negative affect were found in one RCT,[48]. In another RCT,[42], 12-weeks of CA significantly increased positive affect compared to HIIT and non-active control, although neither intervention improved negative affect.

\section{Distress}

Two RCTs, $[53,71]$ observed a significant decrease in psychological distress following HIIT regimes of duration 3-10 months, compared to non-active control. In another RCT,[26], 8 weeks of HIIT did not improve psychological distress, compared to non-active control. Moreover, a further RCT,[59] observed a reduction in psychological distress following 12-weeks of HIIT or MICT, and no between-group differences.

\section{Sleep Outcomes}

One RCT observed an improvement in self-reported sleepiness following 12-weeks of HIIT compared to non-active control,[68]. Two RCTs, $[29,81]$ observed no significant between-group differences in sleep quality following 12-weeks of HIIT and non-active control, although one RCT observed a significant within-group improvement in sleep quality in the HIIT group,[29]. 
There was no improvement in either insomnia,[62] nor sleep time,[51] following HIIT regimes of duration 10-12 weeks, compared to MICT.

\section{Acute Mental Health Changes}

Five RCTs evaluated the mental health effects of HIIT and continuous exercise before and after a single training session. Four RCTs, $[45,48,55,78]$ observed no significant between-group differences in multiple mental health measures between HIIT and continuous exercise groups, although one of these RCTs,[78] observed within-group gains in positive, negative and global affect following HIIT, and another observed a significant improvement in acute measures of anxiety compared to non-active control,[45]. In another RCT,[47], HIIT acutely increased stress and negative affect, and decreased positive affect compared to MICT.

\section{Long-term Mental Health Changes}

Nine RCTs assessed the long-term effects of HIIT on mental health symptoms including depression, $[40,41,69,81,84]$, anxiety, $[40,41,69,81,84]$, combined anxiety/depression scales, [84,85], MCS scores,[39-41,75,81], stress,[81], positive and negative affect,[48,69], and sleep quality,[81] in follow-ups ranging from 3-months to 5 -years post HIIT intervention. Compared to both active and non-active controls, there were no significant differences in any of these measures at follow-up except in one RCT where a greater decrease in anxiety was observed in the HIIT group from baseline to 5-year follow-up compared to a non-active control (HIIT mean change $=-0.7$ [95\% $\mathrm{Cl}:-1.5 ; 0.1]$; control mean change $=1.2$ [95\% Cl:-0.0; 2.5]), although when the cut-off values of anxiety were applied the frequency of anxiety showed no significant between-group differences,[41].

\section{Adverse Events}

The occurrence of AEs was measured in 40 RCTs (75.5\%), although it was sometimes unclear if events were exercise-related. Twenty-five RCTs observed no exercise-related AE in HIIT and control conditions, $[25,27,52-54,57,60,61,63,67,71,76,29,81-83,85,86,39-41,46,49-51]$. Two RCTs observed AEs (back pain,[42], cardiac instances,[66] following active control but none following HIIT

Nine RCTs observed non-serious AE following HIIT yet no events following control (across these 9 RCTs 15 exercise-related AEs were observed out of 223 HIIT participants). Events included migraine,[55]), vomiting, dehydration and dizziness,[84], muscle strains,[72], ankle injury,[62], osteoarthritis,[70], cardiac events and dizziness,[69], short-lived angina,[75], bursitis,[65] and back pain, [68].

Three RCTs observed AEs following both HIIT and active control (across these three RCTs $14.6 \%$ of HIIT participants experienced an AE compared to $11.9 \%$ and $5.9 \%$ of continuous exercise and walking participants respectively). Events included musculoskeletal injuries and sprains,[77]), syncope/panicattack,[73]), COPD exacerbations, musculoskeletal pain, chest pain and newly diagnosed cancer,[80]. Another RCT observed 24 exacerbations in COPD patients, but did not specify if these were exerciserelated nor if they occurred following HIIT or MICT,[79].

No RCTs reported AEs in healthy populations (0/8) whereas $40.6 \%$ of RCTs in people with physical health conditions (13/32) reported AEs following HIIT. BMI was reported in 38/40 RCTs that assessed AEs, of which $26.7 \%$ with mean $\mathrm{BMI}<30$ (8/30) observed AEs following HIIT compared to $50 \%$ (4/8) with mean 
BMI 230. Of those RCTs offering non-supervised home based HIIT, 4/6 (66.7\%) observed no AEs, $[27,53,65,67,83]$.

\section{Adherence}

Attendance

to

HIIT

sessions

was

$\geq 90 \%$

in

23

RCTs, $[25,28,59,60,62,63,66,67,69,71,79,81,29,82,85,86,46,47,49,52,55,56,58], \quad \geq 80-89 \% \quad$ in eight RCTs, $[48,50,54,64,68,73,76,80], \geq 70-79 \%$ in five RCTs, $[57,70,72,75,78], \geq 60-69 \%$ in two RCTs, $[44,84]$ and $\geq 50-59 \%$ in four RCTs, $[42,53,65,77]$, although in some instances adherences figures only included programme completers. Adherence rates did not significantly differ between HIIT and active control conditions except for three RCTs of which two RCTs, [48,72] observed greater adherence to HIIT than control (walking and MICT) and one RCT,[77] observed greater adherence to control (walking). One RCT reported adherence to unsupervised home-based HIIT and observed $76.2 \%$ adherence,[70].

Table One- Basic Characteristics of included RCTs, including population characteristics and details of HIIT and control interventions

[insert table here]

Table Two- Mental health findings, adherence and adverse events

[insert table here]

Table Three- Random effects meta-analyses for RCTs comparing HIIT with active and non-active control conditions, and measures of heterogeneity

[insert table here]

Table Four- Subgroup analysis based on HIIT modality, HIIT intervention duration and length, and population character

[insert table here]

\section{DISCUSSION}


To the best of our knowledge, the current systematic review and meta-analysis is the first to compile and appraise an overview of the mental health benefits of HIIT among the general population and those with physical illnesses to date. Depression, anxiety, stress and fluctuating mental wellbeing are highly prevalent in the general population and go easily undetected,[87]. Our paper highlights multiple potential mental health benefits, across a range of ages and physical health statuses, thus suggesting that HIIT is an effective way of improving mental health and may be an alternative to traditional treatments such as medications and therapy, which can carry stigma,[88-90].

In our meta-analysis, HIIT led to moderate improvements in mental wellbeing, depression severity and perceived stress compared to non-active controls, and small improvements in mental wellbeing compared to active controls. Following HIIT, there was no improvement in anxiety severity compared to either active or non-active controls. In our narrative synthesis, there was inconsistency regarding the role of HIIT for psychological distress and sleep outcomes compared to non-active controls, whereas HIIT did not appear to effect positive and negative affect. These narrative findings were hampered by differences in operationalization of mental health concepts/variability of outcome measurement tools, differences in exercise regimes and population characteristics, and small sample size. Taken together, our findings suggest HIIT to be a viable intervention to improve some aspects of mental health and may convey greater benefits that some other forms of exercise for mental wellbeing, although more research is needed to establish the full range of benefits associated with HIIT.

Our subgroup analysis demonstrated greater improvements in mental wellbeing when HIIT was conducted for 7 or more weeks, compared to shorter regimes, and greater improvements in perceived stress when HIIT was conducted at least twice weekly, compared to a lower frequency. These findings are consistent with past work in people with physical illnesses whereby lengthier HIIT regimes, conducted on a frequent basis, were associated with greater health-related gains,[21]. We found no effect of HIIT modality on the significance of mental health gains. Equally, there did not appear to be differences in the magnitude of gain in those with, and those without, physical illness except for perceived stress whereby gains were seen in healthy populations but not those with physical illnesses. However, this finding was based on only four RCTs and should be interpreted with caution. Overall, these results may suggest that HIIT is equally effective for mental health regardless of the exercise modality and physical health status of the individual, or it may be that a larger sample is needed before reliable differences in effectiveness can be observed.

Additionally, we summarised acute and long-term mental health effects of HIIT. One RCT observed a significant improvement in acute measures of anxiety compared to non-active control and another observed acute within-group gains in some mental health measures, but no difference compared to active control, whereas a further RCT observed an acute worsening of mental health following HIIT. More work is needed to establish acute effects. In terms of the long-term benefits of HIIT, it appears that benefits in mental health are not sustained once the HIIT intervention is terminated. Thus, it appears that continuous participation in HIIT regimes is needed to maintain the mental health benefit. This said, there is encouraging evidence from a small number of trials regarding adherence and safety from unsupervised home-based HIIT and future research should focus on the sustainability and outcomes of home-based HIIT once formal supervised interventions end.

HIIT appeared to be safe amongst healthy individuals and those with various physical health conditions. This confirms findings regarding the safety of HIIT in previous research investigating the impact of HIIT in 
both people with physical health conditions and those with mental disorders, [22-24]. Sixty-eight percent of RCTs that measured AEs observed no AEs following HIIT and a further $22.5 \%$ reported only non-serious events. The remaining RCTs did not divulge into the severity of the observed events, but reported musculoskeletal injuries, COPD exacerbations, and syncope, although it was sometimes unclear if HIIT was directly responsible for causing the event, which highlights the importance of studies employing a serious AEs protocol when investigating HIIT,[22]. The rate of AEs did not seem to differ from the rate of AEs reported in active controls (73.9\% (17/23) of active controls experienced no AEs). Interestingly, all RCTs that observed AEs recruited patients with either physical health conditions, or those who were overweight, and $83.3 \%$ of these $\mathrm{RCTs}$ reported a mean $\mathrm{BMI} \geq 25.0 \mathrm{~kg} / \mathrm{m}^{2}$. This implies that clinicians must familiarise themselves with a patient's prior physical health before recommending enrolment in a HIIT regime, and carefully monitor those categorised as overweight/obese, although if a patient is deemed physically fit the risk of injury may be minimal. Of those RCTs that observed AEs, a variety of modalities were employed including cycling, jogging/running and boxing. Thus, it does not appear that certain modalities are more injury prone than others.

To add, 37 RCTs (70\%) gave data regarding attendance, with $62 \%$ reporting $\geq 90 \%$ attendance to HIIT sessions and only $10.8 \%$ reporting attendance to be as low as $52-59 \%,[42,53,65,77]$. Attendance did not appear to differ from active control conditions. Of those RCTs that reported $\geq 90 \%$ attendance to HIIT, all except one,[60] conducted HIIT on a more than weekly basis, and 70\% (16/23 RCTs) conducted HIIT 3-5 times weekly. It may be that conducting HIIT on a more than weekly basis is beneficial to maintain motivation for ongoing attendance. High attendance was seen in RCTs conducted in a range of HIIT modalities, settings, intervention lengths and population characteristics suggesting that differing HIIT regimes can be acceptable to participants, and both healthy subjects and those with physical illnesses may be keen to participate, which is in contrast to the longstanding argument that HIIT may be too difficult or unpleasant for people to engage in,[91,92]. It may be that other factors, such as the expertise of the instructor, are more influential for attendance although few RCTs reported low attendance thus no patterns could be observed.

Greater mental health symptom severity at baseline was associated with greater mental health gains, although only one RCT compared changes in mental health parameters and baseline mental health symptom severity,[63]. This RCT observed no differences in mental wellbeing, depression severity and mood in their total sample of women at-risk for MetS following HIIT, but in participants with low baseline scores (more than 1 standard deviation from the normative value), clinically significant gains were seen in these measures,[63].

Participants with a broad range of physical health conditions were included in our systematic review and meta-analysis including cardiometabolic disorders, COPD, cancer, Crohn's disease and SSc, however there were not sufficient studies in each condition and each mental health outcome to allow for a subgroup analysis based on individual diagnosis. This said, a range of benefits were seen in a range of participant groups across individual studies. Thus, it seems likely that HIIT has mental health benefits across numerous physical health conditions. This is important because co-morbid depression, anxiety and stress are 2-3 times more likely in people with chronic physical illnesses, which can worsen physical outcomes and lead to increased disability,[93-95], and thus, need targeting.

Future research could consider individual preference and explore satisfaction with HIIT compared to other forms of exercise and evaluate whether HIIT may protect against the emergence of mental health 
problems. Moreover, it is important to note that $75.5 \%$ of included RCTs (40/53 RCTs) measured mental health as a secondary outcome. This is important because randomization procedures and number of participants needed in analysis may have been calculated with the primary outcome in mind, thus future research with mental health as the primary outcome is required.

Overall, the description of interventions tended to be reported in sufficient detail to allow accurate replication. A majority of studies reported equipment used, intervention procedure and supervision status in detail. That said, only $45 \%$ of studies reported mode of delivery (group/individual setting), $36 \%$ reported motivational strategies and $0 \%$ reported modifications. It could be that few reported motivational strategies and modifications because no motivational strategies or modifications were used, although this should be explicitly stated along with mode of delivery in future trials.

Despite our encouraging findings, it is important to note several limitations with the systematic review. Firstly, the quality of the intervention studies included was mixed (PEDro scores ranged from 4-8), namely only $30.2 \%$ analyzed results on an ITT basis and only $39.6 \%$ blinded assessors. Thus, caution is required when interpreting the findings. Future, high-quality RCTs are required. Secondly, sleep outcomes, psychological distress, and positive and negative affect were summarised narratively owing to the small number of trials assessing these parameters. Thirdly, there were minimal RCTs focussing on younger people and older adults and future research is warranted in these populations to clarify the mental health benefits. Additionally, no subgroup analysis was conducted accounting for baseline mental health symptom severity. It may be that HIIT has greater clinical efficacy in terms of mental health outcomes in people with more severe symptoms at baseline than our meta-analysis would suggest and may have been masked by those with reduced mental health symptom severity. This said, there was not enough variety in baseline mental health symptomology to conduct a separate subgroup analysis. For example, of the 17 studies assessing depression, 13 had a mean baseline depression rating below clinical threshold, [27,42,82-84,54,60-63,70,79,81], four had a mean depression rating demonstrating borderline levels for subthreshold depression, $[28,43,56,80]$ yet none met severity for clinical depression. Similarly, 10/14 studies assessing anxiety had a mean baseline anxiety rating below clinical threshold,[28,43,44,54,61-63,81,82,84], 4/14 demonstrated borderline levels for subthreshold anxiety, $[56,60,79,80]$ and none met severity for clinical anxiety. More research into the effect of baseline mental health symptom severity and magnitude of mental health gains is needed.

\section{CONCLUSION}

HIIT appears to lead to moderate improvements in mental wellbeing, depression severity, and perceived stress compared to non-active controls, and small improvements in mental wellbeing compared to active controls. Additionally, HIIT may improve sleep outcomes and psychological distress compared to nonactive controls and appears to have good attendance and safety among a broad range of populations. Taken together, these findings offer support to the use of HIIT for mental health.

\section{DECLARATIONS}

Ethics approval and consent to participate - Not applicable 
Consent for publication - Not applicable

Availability of data and material - All data analysed during this study is included in this published article and its supplementary information files.

Funding - This paper represents independent research funded by the National Institute for Health Research (NIHR) Biomedical Research Centre at South London and Maudsley NHS Foundation Trust and King's College London. RM is supported by a PhD studentship from the NIHR Biomedical Research Centre at South London and Maudsley NHS Foundation Trust and King's College London. BS is supported by a Clinical Lectureship (ICA-CL-2017-03-001) jointly funded by Health Education England (HEE) and the National Institute for Health Research (NIHR). The views expressed are those of the authors and not necessarily those of the NHS, the NIHR or the Department of Health and Social Care. The funding partners had no involvement in the study at any stage, nor did they influence the decision to publish. JF is supported by a University of Manchester Presidential Fellowship (P123958) and a UK Research and Innovation Future Leaders Fellowship (MR/T021780/1).

Authors' contributions - RM and BS designed the systematic review and meta-analysis and search criteria. RM, NK and BS determined study eligibility. RM and NK assessed study quality. Data extraction was performed by RM and BS conducted statistical analysis; guidance was provided by $\Pi T$. The paper was drafted by RM and revised by BS. All authors contributed to protocol development and read and approved the final manuscript.

Acknowledgements - Not applicable

Conflicts of Interest- BS has received Honoria from ASICS. BS and JF have received Honoria from Parachutebh, for an unrelated project.

\section{LIST OF ABBREVIATIONS}

coronary artery disease: CAD 
Consensus on Exercise Reporting Template: CERT

confidence interval: $\mathrm{Cl}$

chronic obstructive pulmonary disease: COPD

continuous training at high intensity: $\mathrm{CTHI}$

continuous training at ventilatory threshold: CTVT

cutaneous systemic sclerosis: SSc

Physiotherapy Evidence Base Database: PEDro

effect sizes: ES

High intensity interval training: HIIT

HIIT adding whole-body electromyostimulation training: HIITEMS

heart rate peak: HRpeak

intention-to-treat: ITT

mental component score: MCS

metabolic syndrome: MetS

Myocardial Infarction: MI

moderate intensity continuous training: MICT

Short-Form 36 Health Survey: SF-36

sprint interval training: SIT

standardized mean difference: SMD

randomised controlled trials: RCTs

\section{REFERENCES}

1 Black S V., Cooper R, Martin KR, et al. Physical Activity and Mental Well-being in a Cohort Aged 60-64 Years. Am J Prev Med Published Online First: 2015. doi:10.1016/j.amepre.2015.03.009

2 Dunn AL, Trivedi MH, O'Neal HA. Physical activity dose-response effects on outcomes of depression and anxiety. In: Medicine and Science in Sports and Exercise. 2001. doi:10.1097/00005768-200106001-00027

3 Teychenne M, Ball K, Salmon J. Physical activity and likelihood of depression in adults: A review. Prev. Med. (Baltim). 2008. doi:10.1016/j.ypmed.2008.01.009 
Firth J, Solmi M, Wootton RE, et al. A meta-review of "lifestyle psychiatry": the role of exercise, smoking, diet and sleep in the prevention and treatment of mental disorders. World Psychiatry Published Online First: 2020. doi:10.1002/wps.20773

5 Demissie Z, Siega-Riz AM, Evenson KR, et al. Associations between physical activity and postpartum depressive symptoms. J Women's Heal Published Online First: 2011. doi:10.1089/jwh.2010.2091

6 Park SH, Han KS, Kang CB. Effects of exercise programs on depressive symptoms, quality of life, and self-esteem in older people: A systematic review of randomized controlled trials. Appl Nurs Res Published Online First: 2014. doi:10.1016/j.apnr.2014.01.004

7 Josefsson T, Lindwall M, Archer T. Physical exercise intervention in depressive disorders: Metaanalysis and systematic review. Scand. J. Med. Sci. Sport. 2014. doi:10.1111/sms.12050

Adamson BC, Ensari I, Motl RW. Effect of Exercise on Depressive Symptoms in Adults With Neurologic Disorders: A Systematic Review and Meta-Analysis. Arch. Phys. Med. Rehabil. 2015. doi:10.1016/j.apmr.2015.01.005

9 Coventry PA, Hind D. Comprehensive pulmonary rehabilitation for anxiety and depression in adults with chronic obstructive pulmonary disease: Systematic review and meta-analysis. J. Psychosom. Res. 2007. doi:10.1016/j.jpsychores.2007.08.002

10 Herring MP, Puetz TW, O'Connor PJ, et al. Effect of exercise training on depressive symptoms among patients with a chronic illness: A systematic review and meta-analysis of randomized controlled trials. Arch. Intern. Med. 2012. doi:10.1001/archinternmed.2011.696

11 Van Der Heijden MMP, Van Dooren FEP, Pop VJM, et al. Effects of exercise training on quality of life, symptoms of depression, symptoms of anxiety and emotional well-being in type 2 diabetes mellitus: A systematic review. Diabetologia. 2013. doi:10.1007/s00125-013-2871-7

12 Awick EA, Ehlers DK, Aguiñaga S, et al. Effects of a randomized exercise trial on physical activity, psychological distress and quality of life in older adults. Gen Hosp Psychiatry Published Online First: 2017. doi:10.1016/j.genhosppsych.2017.06.005

13 Das Neves MKM, Loots JM, Van Niekerk RL. The effect of various physical exercise modes on perceived psychological stress. South African J Sport Med Published Online First: 2014. doi:10.7196/sajsm.476

14 Norris R, Carroll D, Cochrane R. The effects of physical activity and exercise training on psychological stress and well-being in an adolescent population. J Psychosom Res Published Online First: 1992. doi:10.1016/0022-3999(92)90114-H

Wang $\mathrm{CW}$, Chan $\mathrm{CHY}$, Ho RTH, et al. Managing stress and anxiety through qigong exercise in healthy adults: A systematic review and meta-analysis of randomized controlled trials. $B M C$ Complement Altern Med Published Online First: 2014. doi:10.1186/1472-6882-14-8

16 Banno $M$, Harada $\mathrm{Y}$, Taniguchi $\mathrm{M}$, et al. Exercise can improve sleep quality: A systematic review and meta-analysis. PeerJ Published Online First: 2018. doi:10.7717/peerj.5172

17 Yang PY, Ho KH, Chen HC, et al. Exercise training improves sleep quality in middle-aged and older adults with sleep problems: A systematic review. J Physiother Published Online First: 2012. doi:10.1016/S1836-9553(12)70106-6 
Rubio-Arias J, Marín-Cascales E, Ramos-Campo DJ, et al. Effect of exercise on sleep quality and insomnia in middle-aged women: A systematic review and meta-analysis of randomized controlled trials. Maturitas. 2017. doi:10.1016/j.maturitas.2017.04.003

19 Reed J, Ones DS. The effect of acute aerobic exercise on positive activated affect: A metaanalysis. Psychol Sport Exerc Published Online First: 2006. doi:10.1016/j.psychsport.2005.11.003

20 Szabo A. Acute psychological benefits of exercise: Reconsideration of the placebo effect. J Ment Heal Published Online First: 2013. doi:10.3109/09638237.2012.734657

Martland R, Mondelli V, Gaughran F, et al. Can high-intensity interval training improve physical and mental health outcomes? A meta-review of 33 systematic reviews across the lifespan. $J$ Sports Sci Published Online First: 2020. doi:10.1080/02640414.2019.1706829

22 Weston KS, Wisløff U, Coombes JS. High-intensity interval training in patients with lifestyleinduced cardiometabolic disease: A systematic review and meta-analysis. Br J Sports Med 2014;48:1227-34. doi:10.1136/bjsports-2013-092576

23 Martland R, Mondelli V, Gaughran F, et al. Can high intensity interval training improve health outcomes among people with mental illness? A systematic review and preliminary meta-analysis of intervention studies across a range of mental illnesses. J Affect Disord 2020;263. doi:10.1016/j.jad.2019.11.039

24 Korman N, Armour M, Chapman J, et al. High Intensity Interval training (HIIT) for people with severe mental illness: A systematic review \& meta-analysis of intervention studies- considering diverse approaches for mental and physical recovery. Psychiatry Res. 2020. doi:10.1016/j.psychres.2019.112601

25 Abdelhalem AM, Shabana AM, Onsy AM, et al. High intensity interval training exercise as a novel protocol for cardiac rehabilitation program in ischemic Egyptian patients with mild left ventricular dysfunction. Egypt Hear J Published Online First: 2018. doi:10.1016/j.ehj.2018.07.008

Costigan SA, Eather N, Plotnikoff RC, et al. High-Intensity Interval Training for Cognitive and Mental Health in Adolescents. Med Sci Sports Exerc Published Online First: 2016. doi:10.1249/MSS.0000000000000993

27 Chrysohoou C, Tsitsinakis G, Vogiatzis I, et al. High intensity, interval exercise improves quality of life of patients with chronic heart failure: A randomized controlled trial. QJM Published Online First: 2014. doi:10.1093/qjmed/hct194

28 Lucibello KM, Paolucci EM, Graham JD, et al. A randomized control trial investigating highintensity interval training and mental health: A novel non-responder phenotype related to anxiety in young adults. Ment Health Phys Act Published Online First: 2020. doi:10.1016/j.mhpa.2020.100327

29 Jurado-Fasoli L, De-la-O A, Molina-Hidalgo C, et al. Exercise training improves sleep quality: A randomized controlled trial. Eur J Clin Invest Published Online First: 2020. doi:10.1111/eci.13202

30 Sherrington C, Moseley AM, Herbert RD, et al. Editorial: Ten years of evidence to guide physiotherapy interventions: Physiotherapy evidence database (PEDro). Br J Sports Med 2010;44:836-7. doi:10.1136/bjsm.2009.066357

31 Slade SC, Dionne CE, Underwood M, et al. Consensus on Exercise Reporting Template (CERT): 
Explanation and Elaboration Statement. Br J Sports Med 2016;50:1428-37. doi:10.1136/bjsports2016-096651

Cohen S. Perceived tress cale. Psychology 1994.

Jenkinson C, Coulter A, Wright L. Short form 36 (SF 36) health survey questionnaire: Normative data for adults of working age. Br Med J Published Online First: 1993.

doi:10.1136/bmj.306.6890.1437

Ware J, Kosinski M, Keller S. SF-36 Physical and Mental Health Summary Scales: A User's Manual. A user's Man 1994.

Bakker A, Cai J, English L, et al. Beyond small, medium, or large: points of consideration when interpreting effect sizes. Educ. Stud. Math. 2019. doi:10.1007/s10649-019-09908-4

Begg CB, Mazumdar M. Operating Characteristics of a Rank Correlation Test for Publication Bias. Biometrics Published Online First: 1994. doi:10.2307/2533446

Egger M, Smith GD, Schneider M, et al. Bias in meta-analysis detected by a simple, graphical test. Br Med J Published Online First: 1997. doi:10.1136/bmj.315.7109.629

Duval S, Tweedie R. Trim and fill: A simple funnel-plot-based method of testing and adjusting for publication bias in meta-analysis. Biometrics Published Online First: 2000. doi:10.1111/j.0006341X.2000.00455.x

Pattyn N, Vanhees L, Cornelissen VA, et al. The long-term effects of a randomized trial comparing aerobic interval versus continuous training in coronary artery disease patients: 1-year data from the SAINTEX-CAD study. Eur J Prev Cardiol Published Online First: 2016.

doi:10.1177/2047487316631200

40 Rolid K, Andreassen AK, Yardley M, et al. Long-term effects of high-intensity training vs moderate intensity training in heart transplant recipients: A 3-year follow-up study of the randomizedcontrolled HITTS study. Am J Transplant Published Online First: 2020. doi:10.1111/ajt.16087

41 Yardley M, Gullestad L, Bendz B, et al. Long-term effects of high-intensity interval training in heart transplant recipients: A 5-year follow-up study of a randomized controlled trial. Clin Transplant Published Online First: 2017. doi:10.1111/ctr.12868

42 Allen A, Carlson SC, Bosch TA, et al. High-intensity Interval Training and Continuous Aerobic Exercise Interventions to Promote Self-initiated Quit Attempts in Young Adults Who Smoke: Feasibility, Acceptability, and Lessons Learned From a Randomized Pilot Trial. J Addict Med 2018;12:373-80. doi:10.1097/ADM.0000000000000414

43 May RW, Seibert GS, Sanchez-Gonzalez MA, et al. Self-regulatory biofeedback training: an intervention to reduce school burnout and improve cardiac functioning in college students. Stress Published Online First: 2019. doi:10.1080/10253890.2018.1501021

44 Eather N, Riley N, Miller A, et al. Efficacy and feasibility of HIIT training for university students: The Uni-HIIT RCT. J Sci Med Sport Published Online First: 2019. doi:10.1016/j.jsams.2018.11.016

Mason JE, Asmundson GJG. A single bout of either sprint interval training or moderate intensity continuous training reduces anxiety sensitivity: A randomized controlled trial. Ment Health Phys Act Published Online First: 2018. doi:10.1016/j.mhpa.2018.02.006 
Connolly LJ, Bailey SJ, Krustrup P, et al. Effects of self-paced interval and continuous training on health markers in women. Eur J Appl Physiol Published Online First: 2017. doi:10.1007/s00421017-3715-9

47 Saanijoki T, Nummenmaa L, Eskelinen JJ, et al. Affective Responses to Repeated Sessions of HighIntensity Interval Training. Med Sci Sports Exerc Published Online First: 2015. doi:10.1249/MSS.0000000000000721

48 Shepherd SO, Wilson OJ, Taylor AS, et al. Low-volume high-intensity interval training in a gym setting improves cardio-metabolic and psychological health. PLoS One Published Online First: 2015. doi:10.1371/journal.pone.0139056

49 Stavrinou PS, Bogdanis GC, Giannaki CD, et al. High-intensity Interval Training Frequency: Cardiometabolic Effects and Quality of Life. Int J Sports Med Published Online First: 2018. doi:10.1055/s-0043-125074

50 Jiménez-García JD, Martínez-Amat A, De La Torre-Cruz MJ, et al. Suspension Training HIIT Improves Gait Speed, Strength and Quality of Life in Older Adults. Int J Sports Med Published Online First: 2019. doi:10.1055/a-0787-1548

51 Bruseghini P, Tam E, Calabria E, et al. High intensity interval training does not have compensatory effects on physical activity levels in older adults. Int J Environ Res Public Health Published Online First: 2020. doi:10.3390/ijerph17031083

52 Hurst C, Weston KL, Weston M. The effect of 12 weeks of combined upper- and lower-body highintensity interval training on muscular and cardiorespiratory fitness in older adults. Aging Clin Exp Res Published Online First: 2019. doi:10.1007/s40520-018-1015-9

53 Leahy AA, Eather N, Smith JJ, et al. Feasibility and preliminary efficacy of a teacher-facilitated high-intensity interval training intervention for older adolescents. Pediatr Exerc Sci Published Online First: 2019. doi:10.1123/pes.2018-0039

54 Nytrøen K, Rolid K, Andreassen AK, et al. Effect of High-Intensity Interval Training in De Novo Heart Transplant Recipients in Scandinavia. Circulation Published Online First: 2019. doi:10.1161/circulationaha.118.036747

55 Saanijoki T, Nummenmaa L, Koivumäki M, et al. Affective Adaptation to Repeated SIT and MICT Protocols in Insulin-Resistant Subjects. Med Sci Sports Exerc Published Online First: 2018. doi:10.1249/MSS.0000000000001415

56 Sosner P, Gayda M, Dupuy O, et al. Ambulatory blood pressure reduction following 2 weeks of high-intensity interval training on an immersed ergocycle. Arch Cardiovasc Dis Published Online First: 2019. doi:10.1016/j.acvd.2019.07.005

57 Pedersen $\mathrm{LR}$, Olsen $\mathrm{RH}$, Jürs $\mathrm{A}$, et al. A randomised trial comparing weight loss with aerobic exercise in overweight individuals with coronary artery disease: The CUT-IT trial. Eur J Prev Cardiol Published Online First: 2015. doi:10.1177/2047487314545280

58 Fu TC, Wang CH, Lin PS, et al. Aerobic interval training improves oxygen uptake efficiency by enhancing cerebral and muscular hemodynamics in patients with heart failure. Int J Cardiol Published Online First: 2013. doi:10.1016/j.ijcard.2011.11.086 
training in type 2 diabetes. Diabetes Res Clin Pract Published Online First: 2013. doi:10.1016/j.diabres.2012.10.019

60 Freyssin C, Verkindt C, Prieur F, et al. Cardiac rehabilitation in chronic heart failure: Effect of an 8week, high-intensity interval training versus continuous training. Arch Phys Med Rehabil Published Online First: 2012. doi:10.1016/j.apmr.2012.03.007

61 Christensen SB, Dall CH, Prescott E, et al. A high-intensity exercise program improves exercise capacity, self-perceived health, anxiety and depression in heart transplant recipients: A randomized, controlled trial. J. Hear. Lung Transplant. 2012. doi:10.1016/j.healun.2011.10.014

Choi HY, Han HJ, Choi J won, et al. Superior effects of high-intensity interval training compared to conventional therapy on cardiovascular and psychological aspects in myocardial infarction. Ann Rehabil Med 2018;42:145-53. doi:10.5535/arm.2018.42.1.145

63 Freese EC, Acitelli RM, Gist NH, et al. Effect of six weeks of sprint interval training on mood and perceived health in women at risk for metabolic syndrome. J Sport Exerc Psychol Published Online First: 2014. doi:10.1123/jsep.2014-0083

64 Chou CH, Fu TC, Tsai HH, et al. High-intensity interval training enhances mitochondrial bioenergetics of platelets in patients with heart failure. Int J Cardiol Published Online First: 2019. doi:10.1016/j.ijcard.2018.07.104

65 Malmo V, Nes BM, Amundsen BH, et al. Aerobic interval training reduces the burden of Atrial fibrillation in the short term: A randomized trial. Circulation Published Online First: 2016. doi:10.1161/CIRCULATIONAHA.115.018220

66 Conraads VM, Pattyn N, De Maeyer C, et al. Aerobic interval training and continuous training equally improve aerobic exercise capacity in patients with coronary artery disease: The SAINTEXCAD study. Int J Cardiol Published Online First: 2015. doi:10.1016/j.ijcard.2014.10.155

67 Villelabeitia Jaureguizar K, Vicente-Campos D, Ruiz Bautista L, et al. Effect of High-Intensity Interval Versus Continuous Exercise Training on Functional Capacity and Quality of Life in Patients with Coronary Artery Disease: A randomized clinical trial. J Cardiopulm Rehabil Prev Published Online First: 2016. doi:10.1097/HCR.0000000000000156

68 Karlsen T, Nes BM, Tjønna AE, et al. High-intensity interval training improves obstructive sleep apnoea. BMJ Open Sport Exerc Med Published Online First: 2017. doi:10.1136/bmjsem-2016000155

69 Ellingsen $\varnothing$, Halle M, Conraads V, et al. High-Intensity Interval Training in Patients with Heart Failure with Reduced Ejection Fraction. Circulation Published Online First: 2017. doi:10.1161/CIRCULATIONAHA.116.022924

Lee LS, Tsai MC, Brooks D, et al. Randomised controlled trial in women with coronary artery disease investigating the effects of aerobic interval training versus moderate intensity continuous exercise in cardiac rehabilitation: CAT versus MICE study. BMJ Open Sport Exerc Med Published Online First: 2019. doi:10.1136/bmjsem-2019-000589

Batrakoulis A, Loules G, Georgakouli K, et al. High-intensity interval neuromuscular training promotes exercise behavioral regulation, adherence and weight loss in inactive obese women. Eur J Sport Sci Published Online First: 2019. doi:10.1080/17461391.2019.1663270 
Cheema BS, Davies TB, Stewart M, et al. The feasibility and effectiveness of high-intensity boxing training versus moderate-intensity brisk walking in adults with abdominal obesity: A pilot study. BMC Sports Sci Med Rehabil Published Online First: 2015. doi:10.1186/2052-1847-7-3

73 Koufaki P, Mercer TH, George KP, et al. Low-volume high-intensity interval training vs continuous aerobic cycling in patients with chronic heart failure: A pragmatic randomised clinical trial of feasibility and effectiveness. J Rehabil Med Published Online First: 2014. doi:10.2340/165019771278

74 Svensson S, Eek F, Christiansen L, et al. The effect of different exercise intensities on health related quality of life in people classified as obese. Eur J Physiother Published Online First: 2017. doi:10.1080/21679169.2017.1296021

75 Tew GA, Batterham AM, Colling K, et al. Randomized feasibility trial of high-intensity interval training before elective abdominal aortic aneurysm repair. Br J Surg Published Online First: 2017. doi:10.1002/bjs.10669

76 Stensvold D, Tjønna AE, Skaug EA, et al. Strength training versus aerobic interval training to modify risk factors of metabolic syndrome. J Appl Physiol Published Online First: 2010. doi:10.1152/japplphysiol.00996.2009

77 Lunt H, Draper N, Marshall HC, et al. High intensity interval training in a real world setting: A randomized controlled feasibility study in overweight inactive adults, measuring change in maximal oxygen uptake. PLoS One Published Online First: 2014. doi:10.1371/journal.pone.0083256

78 Rizk AK, Wardini R, Chan-Thim E, et al. Acute responses to exercise training and relationship with exercise adherence in moderate chronic obstructive pulmonary disease. Chron Respir Dis Published Online First: 2015. doi:10.1177/1479972315598691

79 Arnardóttir RH, Boman G, Larsson $\mathrm{K}$, et al. Interval training compared with continuous training in patients with COPD. Respir Med Published Online First: 2007. doi:10.1016/j.rmed.2006.11.004

Puhan MA, Büsching G, Schünemann HJ, et al. Interval versus continuous high-intensity exercise in chronic obstructive pulmonary disease: A randomized trial. Ann Intern Med Published Online First: 2006. doi:10.7326/0003-4819-145-11-200612050-00006

81 Adams SC, Delorey DS, Davenport MH, et al. Effects of high-intensity interval training on fatigue and quality of life in testicular cancer survivors. Br J Cancer Published Online First: 2018. doi:10.1038/s41416-018-0044-7

82 Egegaard T, Rohold J, Lillelund C, et al. Pre-radiotherapy daily exercise training in non-small cell lung cancer: A feasibility study. Reports Pract Oncol Radiother Published Online First: 2019. doi:10.1016/j.rpor.2019.06.003

83 Krawcyk RS, Vinther A, Petersen NC, et al. Effect of home-based high-intensity interval training in patients with lacunar stroke: A randomized controlled trial. Front Neurol Published Online First: 2019. doi:10.3389/fneur.2019.00664

84 Tew GA, Leighton D, Carpenter R, et al. High-intensity interval training and moderate-intensity continuous training in adults with Crohn's disease: A pilot randomised controlled trial. BMC Gastroenterol Published Online First: 2019. doi:10.1186/s12876-019-0936-x 
85 Mitropoulos A, Gumber A, Crank H, et al. The effects of upper and lower limb exercise on the microvascular reactivity in limited cutaneous systemic sclerosis patients. Arthritis Res Ther Published Online First: 2018. doi:10.1186/s13075-018-1605-0

86 Dunne DFJ, Jack S, Jones RP, et al. Randomized clinical trial of prehabilitation before planned liver resection. Br J Surg Published Online First: 2016. doi:10.1002/bjs.10096

87 Demyttenaere K, Bruffaerts R, Posada-Villa J, et al. Prevalence, severity, and unmet need for treatment of mental disorders in the World Health Organization World Mental Health Surveys. J. Am. Med. Assoc. 2004. doi:10.1001/jama.291.21.2581

88 Bowers H, Manion I, Papadopoulos D, et al. Stigma in school-based mental health: Perceptions of young people and service providers. Child Adolesc Ment Health Published Online First: 2013. doi:10.1111/j.1475-3588.2012.00673.x

89 Corrigan P. How stigma interferes with mental health care. Am. Psychol. 2004. doi:10.1037/0003066X.59.7.614

90 Thornicroft G. Stigma and discrimination limit access to mental health care. Epidemiol. Psichiatr. Soc. 2008. doi:10.1017/S1121189X00002621

91 Hardcastle SJ, Ray H, Beale L, et al. Why sprint interval training is inappropriate for a largely sedentary population. Front. Psychol. 2014. doi:10.3389/fpsyg.2014.01505

92 Biddle $\mathrm{SJH}$, Batterham AM. High-intensity interval exercise training for public health: A big HIT or shall we HIT it on the head? Int J Behav Nutr Phys Act Published Online First: 2015.

doi:10.1186/s12966-015-0254-9

93 (UK) NCC for MH. Depression in Adults with a Chronic Physical Health Problem. 2010.

94 Chauvet-Gelinier JC, Bonin B. Stress, anxiety and depression in heart disease patients: A major challenge for cardiac rehabilitation. Ann Phys Rehabil Med Published Online First: 2017. doi:10.1016/j.rehab.2016.09.002

95 Cox S, O'Donoghue AC, McKenna WJ, et al. Health related quality of life and psychological wellbeing in patients with hypertrophic cardiomyopathy. Heart Published Online First: 1997. doi:10.1136/hrt.78.2.182 

Figure One- Prisma flow chart
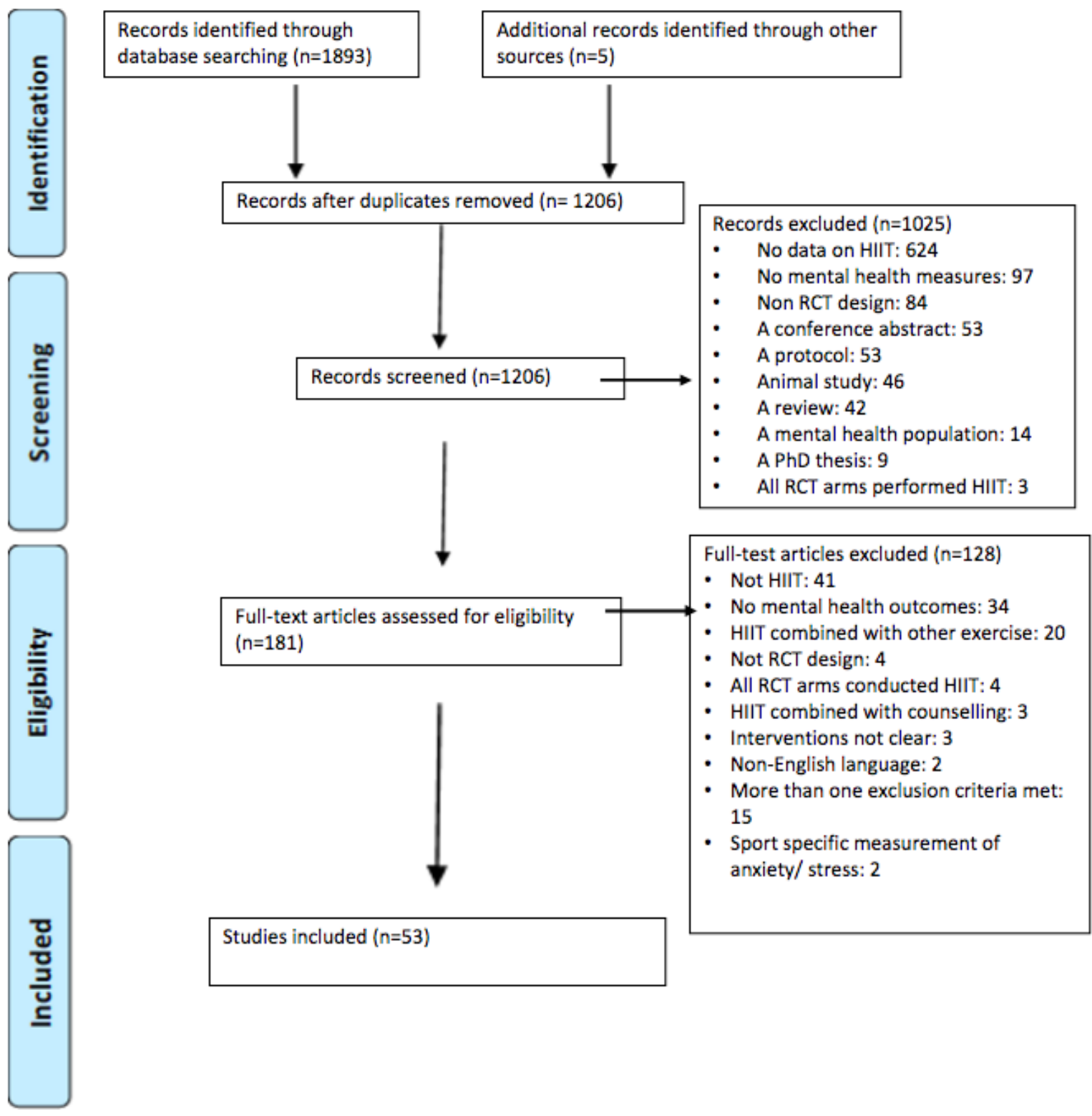

Full-test articles excluded ( $n=128)$

- Not HIIT: 41

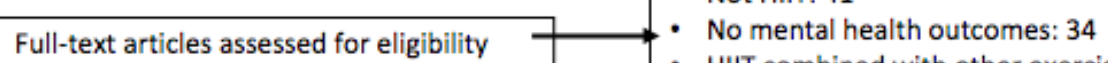

Full-text articles assessed for eligibility
$(n=181)$$\quad$ - HIIT combined with other exercise: 20

- Not RCT design: 4

- All RCT arms conducted HIIT: 4

- HIIT combined with counselling: 3

- Interventions not clear: 3

- Non-English language: 2

- More than one exclusion criteria met: 15

- Sport specific measurement of anxiety/ stress: 2

Studies included $(n=53)$

Figure Two- Forest plot showing changes in MCS score for HIIT versus non-active controls 


\section{Study name}

Adams et al., 2018

Fu et al., 2013

Christensen et al., 2012

Freese et al., 2014

Chou et al., 2019

Hurst et al., 2019

Malmo et al., 2016

Jimenez-Garcia et al., 2019

Svensson et al., 2017

Tew et al., 2017

Stensvold et al., 2010
Statistics for each study

\section{Std diff in}

means

0.762

0.735

0.629

0.021

1.553

0.479

0.139

0.504

0.308

$-0.533$

0.513

\section{Standard Lower Upper}

error

0.265

0.377

0.395

0.292

0.391

0.338

0.280

0.291

0.258

0.280

0.467

0.155

\section{limit}

0.242

$-0.005$

$-0.144$

$-0.551$

0.786

$-0.183$

$-0.410$

$-0.066$

$-0.197$

$-1.081$

$-0.402$

0.124

\section{limit}

\subsection{2}

1.474

1.402

0.593

2.319

1.142

0.689

1.074

0.814

0.015

1.428

0.730

\section{P-value}

0.004
0.051
0.111
0.943
0.000
0.156
0.620
0.083
0.232
0.057
0.272
0.006

Std diff in means and $95 \% \mathrm{Cl}$

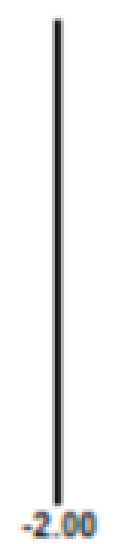

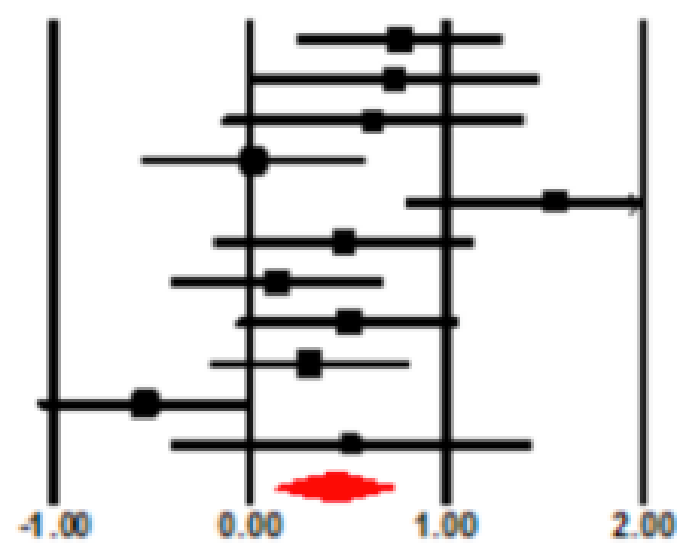

2.00

\section{Favours control Favours HIIT}

Table One- Basic Characteristics of included RCTs, including population characteristics and details of HIIT and control interventions

\begin{tabular}{|c|c|c|c|c|c|}
\hline Study & $\begin{array}{l}\text { Study Design and Sample } \\
\text { Included }\end{array}$ & Sample Size & Sample Characteristics & Exercise Intervention & Control Group \\
\hline $\begin{array}{l}\text { Lucibello et } \\
\text { al., } 2020\end{array}$ & $\begin{array}{l}\text { Two-armed RCT. Young } \\
\text { adults (age 18-30) were } \\
\text { randomized to either } 9 \\
\text { weeks of HIIT or a non- } \\
\text { active control. Effects of } \\
\text { exercise on depressive and } \\
\text { anxiety symptoms were } \\
\text { measured. }\end{array}$ & $\begin{array}{l}\text { HIIT }=28 ; \\
\text { Non-active } \\
\text { Control= } 32\end{array}$ & $\begin{array}{l}\text { Low active young adults, } 63 \% \\
\text { female (HIIT: age } 20.4 \pm 2.6 ; \text { BMI } \\
23.7 \pm 4.5 \text {; Con: age } 19.4 \pm 1.6 ; \mathrm{BMI} \\
21.8 \pm 3.4 \text { ). All were full-time } \\
\text { university students. }\end{array}$ & $\begin{array}{l}\text { Three HIIT sessions per week for nine weeks. HIIT } \\
\text { consisted of } 20 \text { min of intervals on a stationary cycle } \\
\text { ergometer, alternating between a } 1 \text {-min sprint at } ~ 90- \\
95 \% \text { of their HRmax and } 80 \% \text { of Wmax, and } 1 \text { min of } \\
\text { active rest cycling at } 30 \% \text { of Wmax, and a } 3 \text {-min } \\
\text { warm up and } 2 \text {-min cool down at } 50 \mathrm{~W} \text {. }\end{array}$ & $\begin{array}{l}\text { The control group remained } \\
\text { inactive for the nine-week } \\
\text { intervention period. }\end{array}$ \\
\hline $\begin{array}{l}\text { Nytroen et } \\
\text { al., } 2019\end{array}$ & \begin{tabular}{|l|} 
Two-armed multi- \\
centre RCT. De novo heart \\
transplant (HTx) recipients \\
were randomized to either 9 \\
months of either HIIT or \\
MICT. Effects of exercise \\
on mental wellbeing, \\
depressive and anxiety \\
symptoms were measured.
\end{tabular} & $\begin{array}{l}\mathrm{HIT}=39 \\
\mathrm{MICT}=42\end{array}$ & $\begin{array}{l}\text { Clinically stable HTx recipients }>18 \\
\text { years of age (HIT: age } 50 \pm 12, \mathrm{BMI} \\
24.8 \pm 3.4 \text {; MICT: age } 48 \pm 14, \mathrm{BMI} \\
25.6 \pm 3.9 \text { ), and receiving } \\
\text { immunosuppressive therapy, } 73 \% \\
\text { male. Baseline testing was } \\
\text { performed after inclusion at a mean } \\
\text { of } 11 \text { weeks after HTx surgery } \\
\text { (range, } 7-16 \text { weeks). }\end{array}$ & $\begin{array}{l}\text { HIIT consisted of } 25 \text { minutes comprising } 2 \text { - to } 4 \text {-min } \\
\text { intervals at } 85-95 \% \text { of peak effort interspersed with } 3 \text { - } \\
\text { min rest periods performed at } 60- \\
70 \% \text { HRpeak (modality not stated), and a 10min } \\
\text { warm-up and 5-min cool-down conducted at 60- } \\
70 \% \text { HRpeak. The 9-month intervention was divided } \\
\text { into } 3 \text { periods. The first period (3-6 months } \\
\text { after HTx) consisted of } 1 \text { HIIT session, } 1 \text { RT session } \\
\text { (core musculature and large muscle groups), and } 1 \\
\text { combined session per week. The second period (6-9 }\end{array}$ & $\begin{array}{l}\text { The control group performed the } \\
\text { same amount of supervised } \\
\text { physical activity. MICT consisting } \\
\text { of } 25 \text { mins continuous exercise at } \\
60-80 \% \text { of peak effort, regular } \\
\text { core strengthening exercises, and } \\
\text { exercises for large muscle groups. } \\
\text { Each session included a 10min } \\
\text { warm-up and a 5-min cool-down } \\
\text { conducted at } 60-70 \% \text { HRpeak. } \\
\end{array}$ \\
\hline
\end{tabular}




\begin{tabular}{|c|c|c|c|c|c|}
\hline & & & & $\begin{array}{l}\text { months after HTx) consisted of } 2 \text { HIIT sessions and } 1 \\
\text { RT session per week. The last } 2-3 \text { months of the } \\
\text { intervention consisted of } 3 \text { HIIT sessions per week. }\end{array}$ & \\
\hline $\begin{array}{l}\text { Rolid et al., } \\
2020 \text { (3-year } \\
\text { follow-up } \\
\text { of Nytroen et } \\
\text { al., 2019) }\end{array}$ & $\begin{array}{l}\text { Follow-up of a two-armed } \\
\text { RCT. De } \\
\text { novo HTx recipients were } \\
\text { randomized to either nine } \\
\text { months of either HIIT or } \\
\text { MICT. Effects of exercise } \\
\text { on mental wellbeing, } \\
\text { depressive and anxiety } \\
\text { symptoms were measured } \\
\text { at 3-year follow-up. }\end{array}$ & $\begin{array}{l}\text { HIIT=30; } \\
\text { MICT = } 35\end{array}$ & $\begin{array}{l}\text { Clinically stable HTx recipients }>18 \\
\text { years of age. Mean age was } 53 \pm 11 \\
\text { and } 51 \pm 14 \text { in HIIT and MICT } \\
\text { groups respectively, } 75 \% \text { and } 77 \% \\
\text { were male in each group } \\
\text { respectively, donor age was } 36 \pm 14 \\
\text { years and } 37 \pm 14 \text { years in each } \\
\text { group and BMI } 24.6 \pm 2.9 \text { and } \\
25.4 \pm 4 \text {. }\end{array}$ & $\begin{array}{l}\text { HIIT consisted of } 2 \text { - to } 4 \text {-minute intervals at } 85-95 \% \\
\text { of peak effort interspersed with } 3 \text {-minute rest periods } \\
\text { performed at } 60-70 \% \text { HRpeak } 2-3 \text { times each week. } \\
\text { The } 9 \text {-month intervention was divided into } 3 \text { periods, } \\
\text { and the HIIT protocol became progressively more } \\
\text { difficult. }\end{array}$ & $\begin{array}{l}\text { MICT consisting of } 25 \text { minutes } \\
\text { continuous exercise at } 60-80 \% \text { of } \\
\text { peak effort, regular core } \\
\text { strengthening exercises, and } \\
\text { exercises for large muscle groups } \\
\text { 2-3 times each week. }\end{array}$ \\
\hline $\begin{array}{l}\text { Allen et al., } \\
2018\end{array}$ & $\begin{array}{l}\text { Three-armed pilot RCT. } \\
\text { Young adult smokers were } \\
\text { randomized to } 12 \text { weeks of } \\
\text { HIIT, CA or a non-active } \\
\text { control. Effects of exercise } \\
\text { on depression, stress, } \\
\text { positive and negative affect } \\
\text { were measured. }\end{array}$ & $\begin{array}{l}\text { HIIT }=12 ; \\
\text { CA }=9 ; \text { Non- } \\
\text { active } \\
\text { Control }=11\end{array}$ & $\begin{array}{l}\text { Adults ages of } 18 \text { and } 40 \text { (HIIT: age } \\
30.4 \pm 1.5 \text { years, BMI } 25.1 \pm 1.6 ; \text { CA } \\
\text { age } 29.2 \pm 1.8, \text { BMI } 27.3 \pm 2.2 ; \text { Con: } \\
\text { age } 31 \pm 2.2, \text { BMI } 29.1 \pm 2), 63 \% \\
\text { female. Eligible participants } \\
\text { currently smoked }(\geq 5 \text { cigarettes/day } \\
\text { for } \geq \text { last } 6 \text { months), and were } \\
\text { minimally active and in stable } \\
\text { physical/mental health. }\end{array}$ & $\begin{array}{l}\text { HIIT consisted of a single } 20 \text {-min session per week, } \\
\text { on a stationary bike. Each session consisted of } 4 \text {-bouts } \\
\text { of } 30 \text { sec at } 80-90 \text { RPM. During } \\
\text { these bouts participants were encouraged to reach } 75- \\
80 \% \text { of their HRR during weeks } 1-2,80-90 \% \text { HRR } \\
\text { during weeks } 3-5,>90 \% \text { HRR during weeks } 6-12 \text {. } \\
\text { Bouts were interspersed with a two-min at } \\
\text { approximately } 40-50 \text { RPM and } 35-45 \% \text { of HRR. } \\
\text { Sessions began with a 5-min warm-up and ended with } \\
\text { a 3-min cool down. }\end{array}$ & $\begin{array}{l}\text { The CA group completed three } \\
\text { 30-minute sessions per week } \\
\text { starting with mostly walking and } \\
\text { gradually increases to mostly } \\
\text { jogging. The control condition } \\
\text { participants were instructed to } \\
\text { maintain their current activity } \\
\text { level until the end of the study. }\end{array}$ \\
\hline $\begin{array}{l}\text { May et al., } \\
2019\end{array}$ & \begin{tabular}{|l|} 
Three-armed RCT. College \\
students \\
were randomised to 4 \\
weeks of HIIT, heart rate \\
variability coherence \\
biofeedback (HRVCB) \\
training or a non-active \\
control. Effects of exercise \\
on depression and anxiety \\
was measured. \\
\end{tabular} & $\begin{array}{l}\text { HIIT=30; HR } \\
\text { VCB=30; No } \\
\text { n-active } \\
\text { Control=30 }\end{array}$ & \begin{tabular}{|l|} 
College students (mean \pm SD age: \\
$18.55 \pm 0.99$ years, $82 \%$ Female, \\
$71 \%$ Caucasian). Participants were \\
excluded if they exercised regularly \\
$(>120$ min/week), were taking \\
antidepressants or had chronic \\
diseases.
\end{tabular} & $\begin{array}{l}\text { Three cycling sessions per week for } 4 \text { weeks for } 25 \\
\text { min. Each session comprised } 10 \times 60 \text {-s cycling bouts } \\
\text { at } 90 \% \text { HRmax interspersed with } 60 \text {-s recovery at a } \\
\text { resistance of } 50 \mathrm{~W} \text { and included a } 3 \text {-min warm-up and } \\
\text { a } 2 \text {-min cool-down at } 50 \mathrm{~W} \text {. }\end{array}$ & $\begin{array}{l}\text { HRVCB training combines stress } \\
\text { reduction strategies and } \\
\text { biofeedback technologies. } \\
\text { Interactive sessions lasted for } 20 \\
\text { minutes and were conducted } 3 \\
\text { times a week for } 4 \text { weeks. Non- } \\
\text { active control participants were } \\
\text { asked to report their normal daily } \\
\text { activities }\end{array}$ \\
\hline $\begin{array}{l}\text { Krawcyk et } \\
\text { al., } 2019\end{array}$ & \begin{tabular}{|l|} 
Two-armed RCT. Patients \\
with Lacunar stroke \\
were randomised to 12 \\
weeks of HIIT or usual \\
care. Effects of exercise on \\
depressive symptoms was \\
measured.
\end{tabular} & $\begin{array}{l}\text { HIIT }=35 \\
\text { Usual } \\
\text { care }=36\end{array}$ & \begin{tabular}{|l|} 
Patients $\geq 18$ year with a first-time \\
lacunar stroke or a recurrent event of \\
lacunar stroke. In the HIIT group \\
mean age $( \pm$ SD) was 63.7 years \pm \\
$8.9,74 \%$ were male and BMI was \\
$27.5 \pm 4.5$. In the usual care group \\
mean age was $63.7 \pm 9.2$ years, $81 \%$ \\
were male and BMI was $25.6 \pm 3.6$. \\
\end{tabular} & $\begin{array}{l}\text { Home-based HIIT five times a week for } 12 \text { weeks. } \\
\text { Each session consisted of three } 3 \text {-min bouts of high } \\
\text { intensity exercise carried out at } 77-93 \% \text { maxHR and } \\
\text { interspersed with } 2 \text {-min active recovery periods. } \\
\text { Patients were provided with a stationary bicycle for } \\
\text { use at home to ensure an easily accessible exercise } \\
\text { modality. }\end{array}$ & $\begin{array}{l}\text { The usual care group received } \\
\text { secondary preventive medication } \\
\text { and advice on self-managed } \\
\text { lifestyle changes and were asked } \\
\text { to maintain their habitual level of } \\
\text { physical activity and to track their } \\
\text { physical activity in an exercise } \\
\text { diary. }\end{array}$ \\
\hline
\end{tabular}




\begin{tabular}{|c|c|c|c|c|c|}
\hline $\begin{array}{l}\text { Adams et al., } \\
2018\end{array}$ & \begin{tabular}{|l|} 
Two-armed RCT. \\
Testicular cancer survivors \\
were randomised to 12 \\
weeks of HIIT or usual \\
care. Effects of exercise on \\
depression, anxiety, stress \\
and mental wellbeing were \\
measured at end of \\
intervention and 3-month \\
follow-up.
\end{tabular} & $\begin{array}{l}\text { HIIT=35; } \\
\text { Usual } \\
\text { care }=28\end{array}$ & $\begin{array}{l}\text { Men aged } 18-80 \text { years (HIIT: mean } \\
\text { age } 44 \pm 11.6, \text { Con } 43.7 \pm 10.8) \text { with a } \\
\text { confirmed history of stage I-IV } \\
\text { testicular cancer and who were post- } \\
\text { surgery/treatment. } 92.1 \% \text { had a } \\
\text { single orchidectomy, } 36.5 \% \\
\text { received chemotherapy, } 90.5 \% \text { were } \\
\text { Caucasian. }\end{array}$ & \begin{tabular}{|l|} 
Three HIIT sessions per week, consisting of uphill \\
treadmill walking or running for 12 weeks. HIIT \\
consisted of four, 4-minute, high-intensity intervals. \\
The intensity gradually increased from $75 \%$ to $95 \%$ of \\
VO2peak over the intervention. Each interval was \\
separated by a 3-minute active recovery period \\
performed 5-10\% below ventilatory threshold. \\
Session were 35 min in length, including a 5-minute \\
warm-up and a 5-minute cool-down.
\end{tabular} & $\begin{array}{l}\text { Usual care participants were asked } \\
\text { to maintain their baseline exercise } \\
\text { levels. }\end{array}$ \\
\hline $\begin{array}{l}\text { Egegaard et } \\
\text { al., } 2019\end{array}$ & \begin{tabular}{|l|} 
Two-armed pilot RCT. \\
Patients with non-small cell \\
lung cancer (NSCLC) \\
were randomised to 7 \\
weeks of HIIT or a non- \\
active control. Effects of \\
exercise on depression and \\
anxiety were measured.
\end{tabular} & \begin{tabular}{|l} 
HIIT=8; \\
Non-active \\
control=7
\end{tabular} & \begin{tabular}{|l|} 
Patients who were referred for \\
concomitant chemoradiotherapy \\
with locally advanced NSCLC and \\
aged $>18$ years. Mean age was $64 \pm$ \\
5.8 years in the HIIT group and $65 \pm$ \\
4.7 in the control group respectively. \\
$62.5 \%$ and $71.4 \%$ were female in \\
each group respectively, and most \\
had IIIb NSCLC (50.0\% and $57.1 \%$ \\
in each group respectively). Mean \\
BMI was $24.1 \pm 4.4$ and $24.2 \pm 1.9$ in \\
each group.
\end{tabular} & $\begin{array}{l}\text { Five } 20 \text {-min cycling HIIT sessions per week for } 7 \\
\text { weeks. HIIT comprised a } 5 \text {-min warm- } \\
\text { up followed by three } 5 \text {-min exercise phases. Each } \\
\text { session had four phases: The first and the third } \\
\text { exercise phase comprised of interval training } \\
\text { consisting of } 5 \times 30 \text {-s intervals at } 80-95 \% \text { of iPPO, } \\
\text { with each interval separated by a } 30 \text {-s pause. The } \\
\text { second exercise phase consisted of continuous cycling } \\
\text { at } 80 \% \text { PPO. Over the } 7 \text { weeks, the intensities were } \\
\text { increased from } 50 \%, 80 \%, 70 \% \text { and } 80 \% \text { of PPO to } \\
60 \%, 95 \%, 80 \% \text { and } 95 \% \text { of PPO according to the } \\
\text { four phases. }\end{array}$ & $\begin{array}{l}\text { Control patients received no } \\
\text { exercise training. They wore a HR } \\
\text { activity tracker every day to track } \\
\text { activity levels. }\end{array}$ \\
\hline \begin{tabular}{|l} 
Eather et al., \\
2019
\end{tabular} & \begin{tabular}{|l|} 
Two-armed feasibilty RCT. \\
University students \\
were randomised to 8 \\
weeks of HIIT or wait list \\
control. Effects of exercise \\
on anxiety and stress were \\
measured.
\end{tabular} & $\begin{array}{l}\text { HIIT }=27 ; \\
\text { Waist list } \\
\text { Control=26 }\end{array}$ & $\begin{array}{l}\text { Male and female university students } \\
\text { aged } 18-25 \text { years (HIIT: mean age } \\
20.23 \pm 1.72 \text { years, BMI } 24.17 \pm 4.06 \text {; } \\
\text { Con: age } 20.48 \pm 2.01, \text { BMI } \\
22.96 \pm 4.2 \text { ), with no existing medical } \\
\text { conditions. } 34 \% \text { were male, } 88.70 \% \\
\text { Australian, } 32.08 \% \text { overweight or } \\
\text { obese. }\end{array}$ & $\begin{array}{l}\text { Three HIIT sessions per week for } 8 \text { weeks lasting 8- } \\
\text { minutes (weeks 1-4), 10-minutes (weeks 5-6), and 12- } \\
\text { minutes (weeks 7-8) in duration, and a work to rest } \\
\text { ratio of 30secs:30secs. HIIT involved combinations of } \\
\text { aerobic (e.g., shuttles, skips, bear walks) and core } \\
\text { resistance (e.g., push-ups, squats, sit ups) exercises } \\
\text { using either body weight or basic equipment (e.g., } \\
\text { sports balls) and a target HR of 85\% HRmax or above } \\
\text { was promoted. }\end{array}$ & $\begin{array}{l}\text { Participants randomized to the } \\
\text { control conditions were asked to } \\
\text { continue with their usual physical } \\
\text { activity routines during the } \\
\text { intervention period. }\end{array}$ \\
\hline \begin{tabular}{|l|} 
Abdelhalem \\
et al., 2018
\end{tabular} & $\begin{array}{l}\text { Two-armed RCT. Ischemic } \\
\text { Egyptian patients with mild } \\
\text { left ventricular dysfunction } \\
\text { were randomised to } 12 \\
\text { weeks of MICT or HIIT. } \\
\text { Effects of exercise on } \\
\text { emotional wellbeing were } \\
\text { measured. }\end{array}$ & $\begin{array}{l}\text { HIIT=20; } \\
\text { MICT=20 }\end{array}$ & \begin{tabular}{|l|} 
Egyptian patients with CAD, age \\
>18 years old with LV ejection \\
fraction. Mean age was $51.95 \pm 8.07$ \\
years (range $38-67$ years) and \\
$54.65 \pm 7.63$ (range 35-65) in MICT \\
and HIIT groups respectively. $80 \%$ \\
and $90 \%$ of participants were male \\
in MICT and HIT groups \\
respectively. Mean BMI was 29.3 \\
and 30.2 in each group.
\end{tabular} & $\begin{array}{l}\text { HIIT was performed twice weekly for } 12 \text { weeks and } \\
\text { consisted of } 5 \text { min of warm-up exercises followed by } \\
30-35 \text { min of treadmill exercise comprising higher } \\
\text { intensity bouts ( } 2-5 \text { minutes at } 85-95 \% \text { HRR) } \\
\text { interspersed with } 2-5 \text { minutes of moderate-intensity } \\
\text { workloads, and a } 5 \text { min cool down. }\end{array}$ & \begin{tabular}{|l|} 
MICT was performed twice \\
weekly for 12 weeks. Exercise \\
consisted of 5 min of warm-up \\
exercises followed by $30-35$ min \\
of continuous treadmill exercise at \\
$40-60 \%$ of HRR, and a 5 min cool \\
down.
\end{tabular} \\
\hline
\end{tabular}




\begin{tabular}{|c|c|c|c|c|c|}
\hline $\begin{array}{l}\text { Mason et al., } \\
2018\end{array}$ & $\begin{array}{l}\text { Three-armed RCT. Healthy } \\
\text { adults were randomised to a } \\
\text { single session of MICT, } \\
\text { SIT or a non-active control. } \\
\text { Effects of exercise on } \\
\text { anxiety and distress were } \\
\text { measured immediately after } \\
\text { the exercise session and } \\
\text { at } 3 \text { and } 7 \text { day follow-ups. }\end{array}$ & $\begin{array}{l}\text { SIT }=22 ; \\
\text { MICT }=21 \\
\text { Control }=21\end{array}$ & $\begin{array}{l}\text { Undergraduate students and } \\
\text { community members, aged } 18-65 \\
\text { years, who completed less than } \\
150 \text { min of moderate intensity } \\
\text { exercise each week. Mean age was } \\
23.34 \pm 8.23,27.75 \pm 12.91 \text {, and } \\
22.81 \pm 5.99 \text { in control, MICT and } \\
\text { SIT groups respectively, } 75 \%, 80 \% \\
\text { and } 87 \% \text { were female in each group } \\
\text { and mean BMI was } 26.55 \pm 5.62, \\
24.83 \pm 4.56, \text { and } 24.57 \pm 4.22 \\
\text { respectively. }\end{array}$ & $\begin{array}{l}\text { Participants completed a single 10-minute session of } \\
\text { SIT. SIT included a 2-min warm-up, followed by } \\
\text { three 20-s cycle sprints against an applied resistance } \\
\text { at an intensity at or above } 18 \text { RPE and } 85 \% \text { of } \\
\text { HRmax, and separated by an active recovery } \\
\text { consisting of } 2 \text { min of low intensity cycling. SIT was } \\
\text { followed by a 3-min cool-down. }\end{array}$ & $\begin{array}{l}\text { MICT participants completed a } \\
\text { single 50-minute session. MICT } \\
\text { started with a 2-min warm } \\
\text { followed by } 45 \text { min of MICT at } \\
70 \% \text { HRmax and RPE } 13-15 \text { on a } \\
\text { stationary spin cycle, then a 3-min } \\
\text { cool down. The non- } \\
\text { active controll did not engage in } \\
\text { any form of exercise training. }\end{array}$ \\
\hline $\begin{array}{l}\text { Saanijoki et } \\
\text { al., } 2017\end{array}$ & \begin{tabular}{|l|} 
Two-armed RCT. Insulin- \\
resistant adults \\
were randomised to 2 \\
weeks of SIT or MICT. \\
Effects of exercise on \\
positive and negative affect \\
and perceived stress were \\
measured.
\end{tabular} & $\begin{array}{l}\text { SIT }=13 ; \\
\text { MICT }=13\end{array}$ & $\begin{array}{l}\text { Participants aged } 40-55 \text { years, with } \\
\text { a BMI } 18.5-35 \mathrm{~kg} \cdot \mathrm{m}-2 \text {, blood } \\
\text { pressure of } \leq 160 / 100 \mathrm{~mm} \mathrm{Hg}, \\
\text { sedentary lifestyle, and impaired } \\
\text { glucose tolerance and HbA1c less } \\
\text { than } 7.5 \mathrm{mmol} \cdot \mathrm{L}-1(\text { age }, 49 \pm 4 \mathrm{yr} \\
\text { BMI, } 30.5 \pm 2.7] \mathrm{kg} \cdot \mathrm{m}-2,38 \% \\
\text { female). }\end{array}$ & $\begin{array}{l}\text { Participants completed } 6 \text { HIIT sessions in } 2 \text { weeks. } \\
\text { SIT comprised a warm-up and } 4 \text { to } 6 \times 30 \mathrm{~s} \text { all out } \\
\text { cycling efforts at maximal cadence with } 4 \text { min } \\
\text { recovery between bouts. The number of bouts was } \\
\text { increased from four to five, and further to six after } \\
\text { every other training session. }\end{array}$ & $\begin{array}{l}\text { MICT participants performed } 6 \\
\text { MICT sessions in } 2 \text { weeks } \\
\text { comprising continuous aerobic } \\
\text { cycling for } 40-60 \text { min at } 60 \% \text { of } \\
\text { peak workload. Training duration } \\
\text { was increased from } 40 \text { to } 50 \text { min } \\
\text { and further to } 60 \text { min after every } \\
\text { other session. }\end{array}$ \\
\hline $\begin{array}{l}\text { Connolly et } \\
\text { al., } 2017\end{array}$ & \begin{tabular}{|l|} 
Three-armed RCT. Inactive \\
women were randomised to \\
12 weeks of HIIT, \\
continuous training (CT), \\
or a non-active control. \\
Effects of exercise on \\
mental wellbeing were \\
measured.
\end{tabular} & $\begin{array}{l}\text { HIIT }=15 ; \text { CT } \\
=15 ; \text { Non- } \\
\text { active } \\
\text { Control=15 }\end{array}$ & $\begin{array}{l}\text { Currently inactive premenopausal } \\
\text { women without known metabolic or } \\
\text { cardiovascular diseases. Women } \\
\text { were assigned to HIIT (age, } 44 \pm 7 \\
\text { years; BMI } 25.3 \pm 4.9), \text { CT (age, } \\
43 \pm 7 \text { years; BMI } 26.9 \pm 6.3) \text {, or a } \\
\text { control group (CON: age, } 45 \pm 7 \\
\text { years; BMI } 28.4 \pm 6.9 \mathrm{~kg}) .\end{array}$ & $\begin{array}{l}\text { Participants completed } 325 \text {-min HIIT sessions each } \\
\text { week for } 12 \text { weeks on a stationary bike. Each } \\
\text { participant completed repeated } 1 \text { min self-paced } \\
\text { exercise bouts comprising } 30 \text { slow-intensity }(\sim 30 \% \text { of } \\
\text { maximum effort), } 20 \text { s moderateintensity }(\sim 50-60 \% \\
\text { of maximum effort) and } 10 \mathrm{~s} \text { high-intensity }(>90 \% \\
\text { maximum effort) cycling. This } 1 \text {-min cycle was } \\
\text { repeated for } 5 \text { min with each } 5 \text { min block separated by } \\
2 \text { min passive recovery. During the first week } \\
\text { participants performed } 3-4 \times 5 \text { min bouts and in } \\
\text { subsequent weeks participants completed } 5 \times 5 \text { min } \\
\text { bouts interspersed with } 2 \text { min recovery. Sessions } \\
\text { included a } 5 \text { min warm up and a } 5 \text { min cool down. }\end{array}$ & $\begin{array}{l}\text { Participants completed } 3 \text { CT } \\
\text { sessions each week for } 12 \text { weeks } \\
\text { on a stationary bike. CT consisted } \\
\text { of cycling continuously at a self- } \\
\text { paced intensity for } 50 \text { min. } \\
\text { Sessions included a } 5 \text { min warm } \\
\text { up and a } 5 \text { min cool down. Non- } \\
\text { active controls continued their } \\
\text { normal daily lives. }\end{array}$ \\
\hline $\begin{array}{l}\text { Sosner et al., } \\
2019\end{array}$ & $\begin{array}{l}\text { Three-armed RCT. } \\
\text { Hypertensive adults } \\
\text { were randomised to } 2 \\
\text { weeks of MICT on dry } \\
\text { land, HIIT on dry land or } \\
\text { HIIT in a swimming pool. } \\
\text { Effects of exercise on mood } \\
\text { profiles were measured. }\end{array}$ & $\begin{array}{l}\text { HIIT dry } \\
\text { land= } 14 ; \\
\text { HIIT } \\
\text { immersed }=1 \\
; \text { MICT dry } \\
\text { land }=14\end{array}$ & $\begin{array}{l}\text { Forty-two participants ( } 22 \mathrm{men}, 20 \\
\text { women; age } 43-80 \text { years). All had } \\
\text { SBP } \geq 130 \mathrm{mmHg} \text { and/or DBP } \geq 85 \\
\text { mmHg and SBP } \geq 180 \mathrm{mmHg} \\
\text { and/or DBP } \geq 110 \mathrm{mmHg} .55 \% \\
\text { participants had an antihypertensive } \\
\text { treatment, } 45 \% \text { had a statin } \\
\text { for dyslipidaemia, } 19 \% \text { had diabetes } \\
\text { mellitus. (HIT dryland: age } 65 \pm 8, \\
\text { BMI 30.7 } \pm 4.7 ; \text { HIITimmersed: age } \\
63 \pm 9, \text { BMI } 28.8 \pm 3.9 ; \text { MICT: age } \\
65 \pm 6, \text { BMI } 29.7 \pm 4.5 \text { ). }\end{array}$ & $\begin{array}{l}\text { Participants completed } 6 \text { exercise sessions on a } \\
\text { stationary cycle ( } 3 \text { times a week for } 2 \text { weeks) of } \\
\text { either HIITdryland or HIITimmersed. } \\
\text { The HIITdryland consisted of a 5-min warm-up, } \\
\text { followed by two } 10 \text {-minute sets of exercise, composed } \\
\text { of repeated phases of } 15 \text { s of cycling at } 100 \% \text { of PPO, } \\
\text { interspersed by } 15 \mathrm{~s} \text { of passive recovery and } 4 \text { min of } \\
\text { passive recovery between the sets, and a 5-min cool- } \\
\text { down. HITTimmersed was performed on a } \\
\text { mechanically braked cycle ergometer in an indoor } \\
\text { swimming pool using the same protocol. }\end{array}$ & $\begin{array}{l}\text { Participants completed } 6 \text { MICT } \\
\text { sessions on a stationary cycle ( } 3 \\
\text { times a week for } 2 \text { weeks). Each } \\
\text { session was preceded by a } 5 \text {-min } \\
\text { warm-up, followed by a } 24-m i n \text { at } \\
50 \% \text { of PPO, then a 5-min cool- } \\
\text { down. }\end{array}$ \\
\hline
\end{tabular}




\begin{tabular}{|c|c|c|c|c|c|}
\hline $\begin{array}{l}\text { Costigan et } \\
\text { al., } 2016\end{array}$ & $\begin{array}{l}\text { Three-armed RCT. } \\
\text { Adolescents } \\
\text { were randomised to } 8 \\
\text { weeks of HIIT, HIIT-RT or } \\
\text { control. Effects of exercise } \\
\text { on psychological well- } \\
\text { being and distress were } \\
\text { measured. }\end{array}$ & $\begin{array}{l}\text { HIIT }=21 ; \\
\text { HIIT-RT }=22 ; \\
\text { Control }=22\end{array}$ & $\begin{array}{l}\text { Participants were students aged } 14- \\
16 \text { years attending study school ( } 45 \\
\text { males, } 20 \text { females). Mean BMI was } \\
22.29 \pm 3.53 \mathrm{~kg}-\mathrm{m} 2 ; 21.72 \pm 2.10 \mathrm{~kg}- \\
\mathrm{m} 2 ; 22.08 \pm 3.56 \mathrm{~kg}-\mathrm{m} 2 \text { in control, } \\
\text { HIIT and HIIT-RT groups } \\
\text { respectively, and mean age was } \\
15.6 \pm 0.6,15.7 \pm 0.7 \text { and } 15.5 \pm 0.6 \\
\text { respectively. }\end{array}$ & $\begin{array}{l}\text { HIIT and HIIT-RT participants completed three HIIT } \\
\text { sessions per week for } 8 \text { weeks. HIIT sessions } \\
\text { (inclusive of a short warm-up including stretching, } 8- \\
10 \text { min of HIIT (weeks 1-3: } 8 \text { min; weeks } 4-6: 9 \text { min; } \\
\text { weeks } 7-8: 10 \text { min) and cooldown). HIIT comprised a } \\
\text { work to rest ratio of } 30: 30 \text { s and target intensity was } \\
\geq 85 \% \text { of HRmax. Activities included shuttle runs, } \\
\text { jumping jacks, and skipping. } \\
\text { Participants randomised to HIIT-RT sessions carried } \\
\text { out a combination of cardiorespiratory and body } \\
\text { weight RT exercises (e.g., shuttle runs, jumping jacks, } \\
\text { skipping, combined with body weight squats, and } \\
\text { push-ups) in the same } 30: 30 \text { s format. }\end{array}$ & $\begin{array}{l}\text { Control participants continued } \\
\text { with their programmed PE and } \\
\text { usual lunchtime activities for the } \\
\text { 8-wk intervention period. }\end{array}$ \\
\hline $\begin{array}{l}\text { Dunne et al., } \\
2016\end{array}$ & \begin{tabular}{|l|} 
Two-armed RCT. Patients \\
undergoing elective liver \\
resection for colorectal \\
liver metastases (CRLM) \\
were randomised to 4 \\
weeks of HIIT or standard \\
care. Effects of exercise on \\
mental wellbeing were \\
measured.
\end{tabular} & $\begin{array}{l}\text { HIIT }=20 \\
\text { Standard } \\
\text { Care }=18\end{array}$ & \begin{tabular}{|l|} 
Patients with resectable CRLM, \\
aged over 18 years (mean age 62 \\
(range $54-69$ ) years, $70 \%$ male, \\
BMI $29.5 \mathrm{~kg} / \mathrm{m} 2$ \\
$\pm 4.1)$. Resectability was defined as \\
metastases deemed surgically \\
treatable with curative intent (either \\
1 - or 2 -stage resection).
\end{tabular} & $\begin{array}{l}\text { Twelve bicycle based HIIT sessions over a } 4 \text {-week } \\
\text { period. The interval sessions included a warm-up and } \\
\text { cool-down, and } 30 \text { min of interval training alternating } \\
\text { between light exercise ( } 60 \% \text { VO2 peak) and vigorous } \\
(>90 \% \text { V02 peak) intensity. }\end{array}$ & $\begin{array}{l}\text { Participants received standard } \\
\text { care. }\end{array}$ \\
\hline $\begin{array}{l}\text { Rizk et al., } \\
2015\end{array}$ & $\begin{array}{l}\text { Three-armed RCT. Patients } \\
\text { with COPD } \\
\text { were randomised to } 12 \\
\text { weeks of continuous } \\
\text { training at high intensity } \\
\text { (CTHI), continuous training } \\
\text { at ventilatory threshold } \\
\text { (CTVT) or HIIT. Effects of } \\
\text { exercise on positive, } \\
\text { negative and global affect } \\
\text { were measured before and } \\
\text { after a single exercise } \\
\text { session. }\end{array}$ & $\begin{array}{l}\text { CTHI }=13 ; \\
\text { CTVT }=12 ; \\
\text { HIIT }=10\end{array}$ & \begin{tabular}{|l|} 
Patients with a COPD diagnosis; \\
aged $\geq 40$ years, with a smoking \\
history $\geq 10$ American pack-years. \\
Mean age was $66 \pm 7,69 \pm 9$ and \\
$67 \pm 11$ in CTHI, CTVT and HIIT \\
groups respectively, mean BMI was \\
$28.3 \pm 4.9 \mathrm{~kg} / \mathrm{m} 2,27.1 \pm 5.4 \mathrm{~kg} / \mathrm{m} 2$ \\
$28.3 \pm 5.4 \mathrm{~kg} / \mathrm{m} 2$ respectively, and \\
$31 \%, 50 \%$ and $40 \%$ were male in \\
each of the three groups.
\end{tabular} & $\begin{array}{l}\text { Three bicycle based HIIT sessions each week for } 12 \\
\text { weeks. IT consisted of } 30 \text {-second intervals at } \\
100 \% \text { Wpeak interspersed with } 30 \text {-second intervals of } \\
\text { unloaded pedalling. Training included a } 10 \text {-min } \\
\text { warm-up and 5-min cool-down. Session duration was } \\
\text { adjusted for each subject using metabolic equations to } \\
\text { equal total amount of work performed to } 25 \text { min of } \\
\text { CTHI. }\end{array}$ & $\begin{array}{l}\text { Three bicycle based sessions each } \\
\text { week for } 12 \text { weeks. CTHI } \\
\text { consisted of } 25 \text { min of pedalling at } \\
80 \% \text { of Wpeak. For CTVT, } \\
\text { participants pedalled continuously } \\
\text { at the HR reached at the } \\
\text { ventilatory threshold. Session } \\
\text { duration for CTVT was adjusted } \\
\text { for each subject using metabolic } \\
\text { equations to equal total amount of } \\
\text { work performed to } 25 \text { min of } \\
\text { CTHI. Training included a } 10 \text {-min } \\
\text { warm-up and 5-min cool-down. } \\
\end{array}$ \\
\hline $\begin{array}{l}\text { Pedersen et } \\
\text { al., } 2015\end{array}$ & \begin{tabular}{|l|} 
Two-armed RCT. Non- \\
diabetic participants with \\
CAD were randomised to \\
12 weeks of HIIT or a low \\
energy diet (LED). Effects \\
of exercise on depression \\
and anxiety were \\
measured.
\end{tabular} & $\begin{array}{l}\text { HIIT }=35 \\
\text { LED }=35\end{array}$ & $\begin{array}{l}\text { Patients with CAD diagnosed more } \\
\text { than } 6 \text { months prior to inclusion, } \\
\text { BMI } 28-40 \mathrm{~m} / \mathrm{kg} 2 \text {, age } 45-75 \text { years } \\
\text { and no diabetes, } 78 \% \text { were men } \\
\text { (HIIT: age } 62.3 \pm 5.7 \text {, BMI } 31.6, \\
\text { LED: age } 63.6 \pm 6.8, \text { BMI } 31.1 \text { ). }\end{array}$ & $\begin{array}{l}\text { Three bicycle based HIIT sessions each week for } 12 \\
\text { weeks. HIIIT consisted of intervals of } 1-4 \text { min, with a } \\
\text { total of } 16 \text { min at } 85-90 \% \text { of VO2peak, Borg scale } \\
17-18, \text { separated by active pauses of } 1-3 \text { min. The } \\
\text { total duration of each training session was } 38 \text { min. } \\
\text { Each session started with a } 10 \text { min warm-up on a } \\
\text { staircase (total of } 73 \text { steps) or on an exercise bike. }\end{array}$ & $\begin{array}{l}\text { Participants maintain a low energy } \\
\text { diet }(800-1000 \mathrm{kcal} / \text { day }) \text { for } 8-10 \\
\text { weeks followed by } 2-4 \text { weeks } \\
\text { transition to a weight maintenance } \\
\text { diet characterised by a high } \\
\text { protein/low glycemic index diet. }\end{array}$ \\
\hline
\end{tabular}




\begin{tabular}{|c|c|c|c|c|c|}
\hline $\begin{array}{l}\text { Saanijoki et } \\
\text { al., } 2015\end{array}$ & $\begin{array}{l}\text { Two-armed RCT. Healthy } \\
\text { middle-aged men were } \\
\text { randomly assigned to } 2 \\
\text { weeks of HIIT or MICT. } \\
\text { Effects of exercise on } \\
\text { perceived stress and } \\
\text { positive and negative affect } \\
\text { were measured. }\end{array}$ & $\begin{array}{l}\text { HIIT }=14 ; \\
\text { MICT }=14\end{array}$ & $\begin{array}{l}\text { Healthy sedentary men (HIIT: age } \\
48 \pm 5, \text { BMI } 25.6 \pm 2.7, \text { MICT: age } \\
48 \pm 5, \text { BMI } 26.1 \pm 2) \text {. All were aged } \\
40-55 \mathrm{yr} \text {, had a BMI of } 18.5-30 \\
\mathrm{~kg} \cdot \mathrm{m}-2, \text { normal fasting blood } \\
\text { glucose concentration, and a } \\
\text { sedentary life. }\end{array}$ & $\begin{array}{l}\text { Six bicycle based HIIT sessions withing a } 2 \text {-week } \\
\text { time period. The HIIT group subjects performed } \\
\text { progressive HIIT exercises consisting of } 4-6 \times 30 \text {-s } \\
\text { maximal sprints against a resistance equivalent to } \\
7.5 \% \text { of whole body weight, with } 4 \text { min of recovery } \\
\text { between the sprints. The number of sprints, starting } \\
\text { from } 4 \text {, increased by one in every second training } \\
\text { session. }\end{array}$ & $\begin{array}{l}\text { Six bicycle based MICT sessions } \\
\text { within a } 2 \text {-week time period. The } \\
\text { MICT group performed } 40 \text { - to } 60- \\
\text { min continuous aerobic cycling } \\
\text { exercises at } 60 \% \text { peak workload. } \\
\text { Training duration increased by } 10 \\
\text { min in every second training } \\
\text { session starting from } 40 \text { min in the } \\
\text { first session. }\end{array}$ \\
\hline $\begin{array}{l}\text { Chrysohoou } \\
\text { et al., } 2014\end{array}$ & $\begin{array}{l}\text { Two-armed RCT. Patients } \\
\text { with chronic heart failure } \\
\text { (CHF) were randomised to } \\
12 \text { weeks of HIIT or a non- } \\
\text { active control. Effects of } \\
\text { exercise on depressive } \\
\text { symptoms was measured. }\end{array}$ & $\begin{array}{l}\text { HIIT }=50 ; \\
\text { Non-active } \\
\text { control }=50\end{array}$ & $\begin{array}{l}\text { Patients with CHF due to left } \\
\text { ventricular systolic dysfunction } \\
\text { (NYHA classes II-IV, ejection } \\
\text { fraction } \leq 50 \% \text { ). Mean age was } 63 \\
\pm 9 \text { in the HIIT group, } 88 \% \text { were } \\
\text { male, years of known CHF was } 4.2 \\
\pm 4.6 \text { and mean BMI was } 28.85 \pm 4.2 \\
\mathrm{~kg} / \mathrm{m} 2 . \text { Mean age was } 56 \pm 11 \text { years } \\
\text { in the control group, } 72 \% \text { were } \\
\text { male, years of known CFH was } 3.9 \\
\pm 4.8 \text { and mean BMI was } 31.3 \pm 7 \\
\mathrm{~kg} / \mathrm{m} 2 .\end{array}$ & $\begin{array}{l}\text { Patients exercised at an intensity equivalent to } \\
80 \% \text { WRpeak and progressively to } 100 \% \\
\text { of WRpeak for } 30 \mathrm{~s} \text { alternated with } 30 \mathrm{~s} \text { of rest for an } \\
\text { accumulative period of } 45 \mathrm{~min} / \text { day, } 3 \text { days/week for } \\
12 \text { consecutive weeks. A cycling based HIIT protocol } \\
\text { was issued. }\end{array}$ & $\begin{array}{l}\text { Patients in the usual care group } \\
\text { were managed as usual by the } \\
\text { admitting physician in the Heart } \\
\text { Failure Unit, and no advice for } \\
\text { any specific exercise protocol was } \\
\text { given. }\end{array}$ \\
\hline $\begin{array}{l}\text { Fu et al., } \\
2013\end{array}$ & $\begin{array}{l}\text { Three-armed RCT. Patients } \\
\text { with heart failure (HF) } \\
\text { were randomised to } 12 \\
\text { weeks of HIIT, MICT or a } \\
\text { non-active control. Effects } \\
\text { of exercise on mental } \\
\text { wellbeing was measured. }\end{array}$ & $\begin{array}{l}\text { HIIT }=15 ; \\
\text { MICT }=15 ; \\
\text { Non-active } \\
\text { control }=15\end{array}$ & $\begin{array}{l}\text { Patients with HF (left ventricular } \\
\text { ejection fraction (LVEF) } \leq 40 \% \text { or } \\
\text { LVEF }>40 \% \text { with episodes of acute } \\
\text { pulmonary edema). Mean age was } \\
67.5 \pm 1.8 \text { years, } 66.3 \pm 2.1 \text { years and } \\
67.8 \pm 2.5 \text { years in HIIT, MICT and } \\
\text { control groups respectively, } 67 \%, \\
64 \% \text { and } 67 \% \text { were male in each } \\
\text { group respectively, HF duration was } \\
4.2 \pm 1.8 \text { years, } 4.5 \pm 2.0 \text { years and } \\
4.3 \pm 1.6 \text { years respectively and mean } \\
\text { BMI was } 24.5,24.4 \text { and } 24.5 \text {. }\end{array}$ & $\begin{array}{l}\text { HIIT was conducted on a bicycle ergometer thrice } \\
\text { weekly for } 12 \text { weeks. HIIT included a } 3 \text {-min warm up, } \\
\text { five } 3 \text {-minute intervals at } 80 \% \text { of VO2peak separated } \\
\text { by } 3 \text {-minute exercise at } 40 \% \text { of VO2peak, a 3-min } \\
\text { cool-down at } 30 \% \text { of VO2peak. }\end{array}$ & $\begin{array}{l}\text { MICT was conducted on a bicycle } \\
\text { ergometer thrice weekly for } 12 \\
\text { weeks. MICT included a 3-min a } \\
\text { warm-up followed by continuous } \\
60 \% \text { of VO2peak for } 30 \text { min, then } \\
\text { a 3-min cool-down at } 30 \% \text { of } \\
\text { VO2peak. The non-active control } \\
\text { subjects followed advice from } \\
\text { their rehabilitation physicians with } \\
\text { regard to home-based physical } \\
\text { activity. }\end{array}$ \\
\hline $\begin{array}{l}\text { Terada et al., } \\
2013\end{array}$ & $\begin{array}{l}\text { Two-armed feasibility } \\
\text { RCT. Patients with Type } 2 \\
\text { Diabetes (T2D) } \\
\text { were randomised to } 12 \\
\text { weeks of HIIT or MICT. } \\
\text { Effects of exercise on } \\
\text { psychological wellbeing } \\
\text { and distress were } \\
\text { measured. }\end{array}$ & $\begin{array}{l}\text { HIIT=7; } \\
\text { MICT }=8\end{array}$ & $\begin{array}{l}\text { Men and women aged between } 55 \\
\text { and } 75 \text { years, diagnosed with T2D } \\
\text { were eligible. Fifteen participants ( } 8 \\
\text { males and } 7 \text { females). Mean age was } \\
62 \pm 3 \text { years and } 63 \pm 5 \text { years in HIIT } \\
\text { and MICT groups respectively, and } \\
\text { T2D duration was } 6 \pm 4 \text { years and } \\
8 \pm 4 \text { years respectively and mean } \\
\text { BMI was } 28.4 \pm 4.1 \text { and } 33.1 \pm 4.5 \text {. }\end{array}$ & $\begin{array}{l}\text { HIIT was conducted } 5 \text { days per week for } 12 \text { weeks. } \\
\text { HIIT involved alternating between } 1 \text {-min intervals at } \\
100 \% \text { average relative intensity (VO2R) followed by } \\
3 \text {-min recovery intervals at } 20 \% \text { VO2R except for one } \\
\text { day each week, when they performed MICT protocol. } \\
\text { Participants were progressed from } 30 \text { min per session } \\
\text { for weeks } 1-4 \text { to } 45 \text { min per session for weeks } 5-8, \\
\text { and then to } 60 \text { min per session for weeks } 9-12 \text {. } \\
\text { Stationary cycling and treadmill walking were } \\
\text { performed alternately for exercise variety. }\end{array}$ & $\begin{array}{l}\text { MICT was conducted } 5 \text { days per } \\
\text { week for } 12 \text { weeks. The MICT } \\
\text { group performed continuous } \\
\text { exercise at } 40 \% \text { VO2R. Session } \\
\text { duration was matched to the HIIT } \\
\text { group, and sessions were } \\
\text { conducted using stationary cycling } \\
\text { and treadmill walking. }\end{array}$ \\
\hline
\end{tabular}




\begin{tabular}{|c|c|c|c|c|c|}
\hline $\begin{array}{l}\text { Freyssin et } \\
\text { al., } 2012\end{array}$ & $\begin{array}{l}\text { Two-armed RCT. Patients } \\
\text { with chronic HF } \\
\text { were randomised to } 8 \\
\text { weeks of HIIT or } \\
\text { continuous training (CT). } \\
\text { Effects of exercise on } \\
\text { symptoms of anxiety and } \\
\text { depression were measured. }\end{array}$ & $\begin{array}{l}\text { HIIT }=12 ; \\
\text { CT }=14\end{array}$ & $\begin{array}{l}\text { Twenty-six patients with stable } \\
\text { chronic HF and a left ventricular } \\
\text { ejection fraction less than } 40 \% \text {. } \\
\text { Participants were receiving a beta- } \\
\text { blocker, diuretic therapy. Mean age } \\
\text { was } 55 \pm 12 \text { and } 54 \pm 9 \text { years in CT } \\
\text { and HIIT groups respectively and } \\
50 \% \text { were male in each group and } \\
\text { mean BMI was } 24.1 \pm 5.4 \text { and } \\
24.8 \pm 4 \text {. }\end{array}$ & $\begin{array}{l}\text { The physical activity program included } 13 \text { hours of } \\
\text { exercise per week ( } 2-3 \mathrm{~h} / \mathrm{d}, 5 \mathrm{~d} / \text { wks comprising HIIT } \\
\text { or CT, } 4 \text { hours of gymnastics , } 3 \text { hours of } \\
\text { balneotherapy and therapeutic educational sessions on } \\
\text { risk factors and physical practice. HIIT included } 6 \\
\text { sessions of } 71 \text { minutes of exercise including a } 10 \text {-min } \\
\text { warm-up, } 12 \text { repetitions of } 30 \text { sec of cycling exercise } \\
\text { (at } 50 \% \text { max power during the first } 4 \text { weeks and } 80 \% \\
\text { max power during the last } 4 \text { weeks), followed by } 60 \\
\text { sec of complete rest. Each training session consisted } \\
\text { of } 3 \text { series ( } 12 \text { repetitions of } 30 \text { s of exercise), } \\
\text { separated by } 5 \text { min of rest. }\end{array}$ & $\begin{array}{l}\text { The CT completed the same } \\
\text { physical activity program but with } \\
\text { HIIT substituted for } 6 \text { sessions of } \\
61 \text { min of CT. Half of the CT was } \\
\text { performed on a treadmill and half } \\
\text { on a cycle ergometer. CT was } \\
\text { composed of a } 10 \text {-min warm-up } \\
\text { followed by } 45 \text { min of aerobic } \\
\text { exercise corresponding to the } \\
\text { heart rate at the first ventilator } \\
\text { threshold (VT1) and a final } 5 \text { min } \\
\text { of active recovery. }\end{array}$ \\
\hline $\begin{array}{l}\text { Christensen } \\
\text { et al., } 2012\end{array}$ & $\begin{array}{l}\text { Sub-study of a two-armed } \\
\text { RCT. Heart transplant } \\
\text { recipients } \\
\text { were randomised to } 8 \\
\text { weeks of HIIT or a non- } \\
\text { active control. Effects of } \\
\text { exercise on symptoms of } \\
\text { anxiety and depression and } \\
\text { mental wellbeing were } \\
\text { measured. }\end{array}$ & $\begin{array}{l}\text { HIIT }=14 ; \\
\text { Non-active } \\
\text { control=13 }\end{array}$ & $\begin{array}{l}\text { Patients were above } 18 \text { years of age, } \\
\text { and were at least } 12 \text { months after } \\
\text { transplantation, none had significant } \\
\text { rejection in the previous } 3 \text { months. } \\
\text { Patients were approximately } 7 \text { years } \\
\text { posttransplant. Patients were all } \\
\text { treated with a calcineurin inhibitor } \\
\text { and an antiproliferative agent. Mean } \\
\text { age was } 53 \pm 11 \text { and } 47 \pm 18 \text { years in } \\
\text { HIIT and control groups } \\
\text { respectively, } 86 \% \text { and } 77 \% \text { were } \\
\text { male and mean BMI was } 26.3 \pm 3.3 \\
\text { and } 26.1 \pm 6 \text {. }\end{array}$ & $\begin{array}{l}\text { Thrice weekly sessions for } 8 \text { weeks using bicycles and } \\
\text { staircase running. Each exercise started with a warm- } \\
\text { up period above } 50 \% \text { of VO } 2 \text { peak and was followed } \\
\text { by } 42 \text { min of HIIT with interval blocks of } 4 \text { min/2 } \\
\text { min/30 s according to } 80 \%, 85 \% \text { and } 90 \% \text { of VO2 } \\
\text { peak and recovery periods of } 1 / 2 \text { min. It was followed } \\
\text { by } 10 \text { min of staircase running at } 80 \% \text { of peak VO2 } \\
\text { and recovery walking at } 50 \% \text { peak VO2. Patient were } \\
\text { given education about the benefits of exercise before } \\
\text { and after training sessions. }\end{array}$ & $\begin{array}{l}\text { The control group did not receive } \\
\text { any training. }\end{array}$ \\
\hline $\begin{array}{l}\text { Arnardottir et } \\
\text { al., } 2007\end{array}$ & $\begin{array}{l}\text { Two-armed RCT. Patients } \\
\text { with COPD } \\
\text { were randomised to } 16 \\
\text { weeks of HIT or MICT. } \\
\text { Effects of exercise on } \\
\text { symptoms of anxiety and } \\
\text { depression and mental } \\
\text { wellbeing were measured. }\end{array}$ & $\begin{array}{l}\mathrm{HIIT}=28 ; \\
\mathrm{MICT}=32\end{array}$ & $\begin{array}{l}\text { Patients with moderate or severe } \\
\text { COPD, all were smokers or ex- } \\
\text { smokers. All had a forced expiratory } \\
\text { volume in } 1 \mathrm{~s}(\mathrm{FEV} 1)<60 \% \text { of } \\
\text { predicted value and FEV1/VC (vital } \\
\text { capacity) }<0.7 \text { after } \\
\text { bronchodilatation. The age range } \\
\text { was } 43-80 \text { years (mean age } 65 \pm 7 \\
\text { and } 64 \pm 8 \text { in HIIT and MICT groups } \\
\text { respectively, and mean BMI was } \\
24.1 \pm 5 \text { and } 23.5 \pm 4.4 \text {. }\end{array}$ & $\begin{array}{l}\text { Bicycle based HIIT sessions twice weekly for } 16 \\
\text { weeks. All sessions started with ergometer cycling. } \\
\text { The target training intensity was } \geqslant 80 \% \text { of the baseline } \\
\text { W peak in the "uphill" intervals ( } 5 \text { intervals, } 3 \text { min } \\
\text { each) and } 30 \%-40 \% \text { of the baseline W peak in the } \\
\text { "downhill" intervals ( } 4 \text { intervals, } 3 \text { min each). Total } \\
\text { cycle time was } 39 \text { min including 6-min warm-up and } \\
\text { cool-down at } 30-40 \% \text { W peak. Both groups took part } \\
\text { in identical callisthenic, relaxation and resistance } \\
\text { training. }\end{array}$ & $\begin{array}{l}\text { Bicycle based MICT sessions } \\
\text { twice weekly for } 16 \text { weeks. The } \\
\text { target training intensity was } \\
\geqslant 65 \% \text { of baseline W } \\
\text { peak. otal cycle time was } 39 \text { min } \\
\text { including 6-min warm-up and } \\
\text { cool-down at } 30-40 \% \text { W peak. }\end{array}$ \\
\hline
\end{tabular}




\begin{tabular}{|c|c|c|c|c|c|}
\hline $\begin{array}{l}\text { Tew et al., } \\
2019\end{array}$ & $\begin{array}{l}\text { Three-armed pilot RCT. } \\
\text { Patients with Crohn's } \\
\text { disease were randomised to } \\
12 \text { weeks of HIIT, MICT or } \\
\text { usual care. Effects of } \\
\text { exercise on anxiety and } \\
\text { depression were measured } \\
\text { at end of intervention and } \\
\text { 6-month follow-up. }\end{array}$ & $\begin{array}{l}\text { HIIT=13; } \\
\text { MICT=12; } \\
\text { Usual } \\
\text { care=11 }\end{array}$ & $\begin{array}{l}\text { Male and female patients, aged 16- } \\
65 \text { years of age (HIIT: } 37 \pm 11.1, \\
\text { MICT } 38.5 \pm 13 \text {, Con } 35 \pm 10 \text { ) with a } \\
\text { clinical diagnosis of Crohn's disease. } \\
\text { Patients had a stool calprotectin of } \\
<250 \mu \mathrm{g} / \mathrm{g} \text {, stable medication } \\
(>4 \text { weeks), and quiescent or } \\
\text { mildly-active disease. A higher } \\
\text { proportion of participants were male } \\
\text { in the HIIT (54\%) and control }(64 \%) \\
\text { groups than the MICT group }(25 \%) . \\
\text { The mean time since diagnosis was } \\
13.7 \text { years (range from } 4 \text { months to } \\
38.2 \text { years). }\end{array}$ & $\begin{array}{l}\text { Three exercise sessions per week for } 12 \text { consecutive } \\
\text { weeks on a cycle ergometer, with each session } \\
\text { comprising a } 5 \text {-min warm-up at } 15 \% \text { of Wpeak, ten } 1- \\
\text { min bouts at } 90 \% \text { Wpeak, interspersed with 1-min } \\
\text { bouts at } 15 \% \text { Wpeak, and then a } 3 \text {-min cool-down at } \\
15 \% \text { Wpeak. After the initial } 12 \text {-week supervised } \\
\text { training period, participants were encouraged to } \\
\text { continue a similar exercise regime on their own. }\end{array}$ & $\begin{array}{l}\text { MICT participants received three } \\
\text { exercise sessions per week for } 12 \\
\text { consecutive weeks on a cycle } \\
\text { ergometer, with each session } \\
\text { comprising a 5-min warm-up at } \\
15 \% \text { of Wpeak, } 30 \text { min at } \\
35 \% \text { Wpeak, and then a 3-min } \\
\text { cool-down at } 15 \% \text { Wpeak. } \\
\text { Participants allocated to usual care } \\
\text { did not receive any supervised } \\
\text { exercise or exercise advice. }\end{array}$ \\
\hline $\begin{array}{l}\text { Choi et al., } \\
2018\end{array}$ & $\begin{array}{l}\text { Two-armed RCT. Patients } \\
\text { with Myocardial Infarction } \\
\text { (MI) were randomised to } \\
18 \text { sessions of HIIT or } \\
\text { MICT. Effects of exercise } \\
\text { on symptoms of anxiety } \\
\text { and depression were } \\
\text { measured. }\end{array}$ & $\begin{array}{l}\text { HIIT=24; } \\
\text { MICT=22 }\end{array}$ & $\begin{array}{l}\text { Patients with first time ST-segment } \\
\text { elevation myocardial infarction } \\
\text { (STEMI) treated by primary } \\
\text { percutaneous coronary intervention } \\
\text { (PCI) with 'low or moderate' risk. } \\
\text { (HIIT: mean age } 57.31 \pm 12.62, \text { BMI } \\
\text { 24.65 } \pm 3.36 \text {; MICT: age } 57.31 \pm \\
12.62, \text { BMI } 26.3 \pm 2.47) \text {. }\end{array}$ & $\begin{array}{l}\text { Eighteen sessions were offered and patients } \\
\text { completed } 1-2 \text { sessions per week for } 9-10 \text { weeks. } \\
\text { HIIT consisted of } 4 \times 4 \text { min exercise periods at } 85- \\
100 \% \text { of HRmax interspersed with } 3 \text { min of recovery } \\
\text { between bouts at } 50-60 \% \text { of HRmax. Training } \\
\text { sessions started with a } 10 \text { min warm-up and finished } \\
\text { with a cool-down at } 40-50 \% \text { of HRmax. }\end{array}$ & $\begin{array}{l}\text { Eighteen sessions were offered } \\
\text { and patients completed } 1-2 \\
\text { sessions per week for } 9-10 \text { weeks. } \\
\text { Patients worked continuously at } \\
60-70 \% \text { of HRmax. Exercise was } \\
\text { continued for the same time- } \\
\text { period as the HIIT group. }\end{array}$ \\
\hline $\begin{array}{l}\text { Shepherd et } \\
\text { al., } 2015\end{array}$ & $\begin{array}{l}\text { Two-armed RCT. Inactive } \\
\text { adults were randomly } \\
\text { assigned to } 10 \text { weeks of } \\
\text { HIIT or MICT. Effects of } \\
\text { exercise on positive and } \\
\text { negative affect and acute } \\
\text { moods were measured post } \\
\text { intervention and at } 3 \\
\text { month follow-up. }\end{array}$ & $\begin{array}{l}\mathrm{HIIT}=46 ; \\
\text { MICT }=44\end{array}$ & $\begin{array}{l}\text { Inactive individuals, aged } 18-60 \\
\text { years were recruited. All subjects } \\
\text { entering the study were free of any } \\
\text { known metabolic or cardiovascular } \\
\text { disease and did not meet current } \\
\text { physical activity guidelines. Mean } \\
\text { age was } 42 \pm 11 \text { and } 43 \pm 11 \text { years in } \\
\text { HIIT and MICT groups respectively, } \\
\text { mean BMI was } 27.7 \pm 5.0 \text { and } \\
27.7 \pm 4.6 \mathrm{~kg} / \mathrm{m} 2 \text { respectively and } \\
33 \% \text { and } 34 \% \text { of each group were } \\
\text { male. }\end{array}$ & $\begin{array}{l}\text { Three bicycle based HIIT sessions per week for } 10 \\
\text { weeks. HIIT included, a } 5 \text { min warm up of low } \\
\text { intensity cycling, repeated high intensity sprints of } \\
\text { between } 15-60 \mathrm{sec} \text { at }>90 \% \text { HRmax, interspersed } \\
\text { with active recovery periods of } 45-120 \mathrm{sec} \text {, and a } 5 \\
\text { min cool down. Each HIT lasted } 18-25 \mathrm{~min} \text {. }\end{array}$ & $\begin{array}{l}\text { Three bicycle based MICT } \\
\text { sessions per week for } 10 \text { weeks. } \\
\text { MICT included a short warm up, } \\
\text { continuous cycling for } 30 \text { min } \\
\text { (week 1) progressing to } 45 \text { min } \\
\text { (week 10) at } 70 \% \text { HRmax, and a } \\
\text { short cool down. Subjects were } \\
\text { also asked to perform } 2 \\
\text { unsupervised moderate-intensity } \\
\text { sessions (brisk walking, jogging, } \\
\text { cycling, or elliptical cross } \\
\text { training) each week. }\end{array}$ \\
\hline $\begin{array}{l}\text { Puhan et al., } \\
2006\end{array}$ & $\begin{array}{l}\text { Two-armed RCT. Patients } \\
\text { with COPD } \\
\text { were randomised to } 3 \\
\text { weeks of HIIT or high } \\
\text { intensity continuous } \\
\text { exercise (HICT). Effects of } \\
\text { exercise on symptoms of } \\
\text { anxiety and depression } \\
\text { were measured at } 5 \\
\text { week follow-up. }\end{array}$ & $\begin{array}{l}\mathrm{HIIT}=48, \\
\mathrm{HICT}=50\end{array}$ & $\begin{array}{l}\text { Patients with COPD as defined by } \\
\text { FEV1-FVC ratio }<70 \% \text { of } \\
\text { predicted, FEV } 1<50 \% \text { of predicted } \\
\text { after bronchodilation }(\text { HIIT: mean } \\
\text { age } 69 \pm 9.2 \text {, BMI } 25.4 \pm 6.9 ; \text { HICT: } \\
\text { age } 68.9 \pm 9.2 \text {, BMI } 24 \pm 5.8)\end{array}$ & $\begin{array}{l}\text { Patients completed } 12-15 \text { bicycle based HIIT sessions } \\
\text { over } 3 \text { weeks. Each session included a } 2 \text {-min warm- } \\
\text { up, } 20 \text {-min alternating between high-intensity } \\
\text { intervals for } 20 \text { sec at } 50 \% \text { of short-term maximum } \\
\text { exercise capacity (corresponding to } 90-100 \% \text { of } \\
\text { normal maximal capacity) and low-intensity intervals } \\
\text { for } 40 \text { sec at } 10 \% \text { of short-term maximum exercise } \\
\text { capacity, and a } 2 \text { min cool-down. }\end{array}$ & $\begin{array}{l}\text { Patients completed } 12-15 \text { bicycle } \\
\text { based HICT sessions over } 3 \\
\text { weeks. Each session began with a } \\
\text { 2-min warm-up at } 20 \% \text { of } \\
\text { maximum exercise capacity, } \\
\text { continuous exercise for } 20 \\
\text { minutes at } 70 \% \text { or more of } \\
\text { maximum exercise capacity, and a } \\
\text { 2-min cool down (gradual } \\
\text { decrease from } 70 \% \text { to } 0 \% \text { ). }\end{array}$ \\
\hline
\end{tabular}




\begin{tabular}{|c|c|c|c|c|c|}
\hline $\begin{array}{l}\text { Freese et al., } \\
2014\end{array}$ & $\begin{array}{l}\text { Two-armed RCT. Women } \\
\text { at risk } \\
\text { for MetS were randomised t } \\
\text { o } 6 \text { weeks of SIT or a non- } \\
\text { active control. }\end{array}$ & $\begin{array}{l}\text { SIT }=23 ; \\
\text { Non-active } \\
\text { control=24 }\end{array}$ & $\begin{array}{l}\text { Women (30-65 years of age) who } \\
\text { were at risk for developing MetS, } \\
\text { defined as having abdominal obesity } \\
\text { (waist circumference }>88 \mathrm{~cm} \text { ) and at } \\
\text { least one of the following - TG } \\
>150 \mathrm{mg} / \mathrm{dL}, \mathrm{HDL}-\text { cholesterol }<50 \\
\mathrm{mg} / \mathrm{dL}, \mathrm{BP}>130 />85 \mathrm{mmHg} \text {, or } \\
\text { fasting glucose }>100 \mathrm{mg} / \mathrm{dL} \text { or on } \\
\text { medication for any of these risk } \\
\text { factors. Mean age was } 51.7 \pm 10.4 \\
\text { and } 52.5 \pm 7.7 \text { years in SIT and } \\
\text { control groups respectively and } \\
\text { mean BMI was } 31.5 \pm 7.1 \text { and } \\
31.5 \pm 6.1 \mathrm{~kg} / \mathrm{m} 2 \text { respectively. }\end{array}$ & $\begin{array}{l}\text { Three bicycle based SIT sessions per week for } 6 \\
\text { weeks. SIT consisted of a 5-min warm-up followed by } \\
\text { repeated } 30 \text {-s all-out cycling sprints against a } \\
\text { resistance of } 0.09 \mathrm{~kg} \text { per kg of fat-free mass } \\
\text { interspersed with } 4 \text { min active recovery periods with } \\
\text { no resistance applied. Participants completed } 4 \text { sprints } \\
\text { during the first } 2 \text { weeks, and the number of sprints } \\
\text { was then increased by one sprint every week until } \\
\text { participants completed } 8 \text { sprints during week } 8 .\end{array}$ & $\begin{array}{l}\text { Participants were instructed to } \\
\text { maintain their pre-study physical } \\
\text { activity. }\end{array}$ \\
\hline $\begin{array}{l}\text { Jurado-Fasoli } \\
\text { et al., } 2020\end{array}$ & \begin{tabular}{|l|} 
i Four-armed RCT. Middle- \\
aged sedentary adults \\
were randomised to a \\
control group, physical \\
activity recommendation \\
from the World Health \\
Organization (PAR), 12 \\
weeks of HIIT or HIIT \\
adding whole- \\
body electromyostimulation \\
training (HITEMS).
\end{tabular} & $\begin{array}{l}\text { Con=20; } \\
\text { PAR=20; } \\
\text { HIIT=20; } \\
\text { HITEMS }=20\end{array}$ & $\begin{array}{l}\text { Middle-aged adults ( } 40 \text { women, } 40 \\
\text { men), aged } 45-65 \text { years. All engaged } \\
\text { in }<20 \text { minutes of moderate- } \\
\text { intensity physical activity on } 3 \\
\text { d/wk over the last } 3 \text { months and } \\
\text { were free of disease. (HIIT: age } \\
53.1 \pm 5.6, \text { BMI } 26.4 \pm 3.1 \text {; PAR: age } \\
54.9 \pm 4.5 \text {, BMI } 25.4 \pm 2.9 \text {; Con: } \\
51.7 \pm 4.1, \text { BMI } 26.7 \pm 3.9 ; \text { HITEMS: } \\
\text { age } 53.4 \pm 5.4, \text { BMI } 28.1 \pm 4.7) \text {. }\end{array}$ & $\begin{array}{l}\text { Two HIIT sessions/week for } 12 \text { weeks performing } \\
\text { two different complementary protocols each week: (a) } \\
\text { treadmill HIIT with long intervals (type A session) } \\
\text { and (b) weight-bearing exercises in circuit form HIIT } \\
\text { with short intervals (type B session). The training } \\
\text { volume was } 40-65 \text { min/wk at }>95 \% \text { of the maximum } \\
\text { oxygen uptake in type A session, and }>120 \% \text { of the } \\
\text { maximum oxygen uptake in type B session. HITEMS } \\
\text { performed HIIT with the addition of electrical } \\
\text { impulses. }\end{array}$ & $\begin{array}{l}\text { The PAR group performed a } \\
\text { concurrent training } 3 \mathrm{~d} / \mathrm{wk} \text { for } 12 \\
\text { weeks comprising } 150 \mathrm{~min} / \mathrm{wk} \text { at } \\
60 \%-65 \% \text { of the HRR for the } \\
\text { endurance training and } ~ 60 \\
\text { min/wk, at a } 40 \%-50 \% \text { of one- } \\
\text { repetition maximum for the RT. } \\
\text { The endurance training section } \\
\text { used treadmill, cycle ergometer } \\
\text { and elliptical ergometer. Weight- } \\
\text { bearing and guided pneumatic } \\
\text { machines were used in RT } \\
\text { section. The control group were } \\
\text { provided with general advice and } \\
\text { were instructed to maintain their } \\
\text { lifestyle. }\end{array}$ \\
\hline $\begin{array}{l}\text { Bruseghini et } \\
\text { al., } 2020\end{array}$ & \begin{tabular}{|l|} 
Two-armed RCT. Older \\
male adults \\
were randomised to 12 \\
weeks of HIIT or MICT. \\
Effects of exercise on sleep \\
time were measured.
\end{tabular} & $\begin{array}{l}\mathrm{HIIT}=12 ; \\
\mathrm{MICT}=12\end{array}$ & $\begin{array}{l}\text { Healthy, elderly male volunteers } \\
\text { aged } 65-75 \text { years. Mean age was } \\
69.4 \pm 4.3 \text { and } 69.67 \pm 4.1 \text { years in } \\
\text { HIIT and MICT groups respectively } \\
\text { and mean BMI was } 26.5 \pm 2.8 \text { and } \\
26.8 \pm 2.9 \mathrm{~kg} / \mathrm{m} 2 \text { in each group } \\
\text { respectively. }\end{array}$ & $\begin{array}{l}\text { Three bicycle based HIIT sessions per week for } 8 \\
\text { weeks. HIIT consisted of } 7 \times 2 \text { min bouts at } 85-95 \% \\
\text { of VO2max interspersed by } 2 \text { min of recovery at } 40 \% \\
\text { of VO2max. Each session begun with a } 10 \text {-min warm- } \\
\text { up. The training session lasted from } 45-60 \text { min. }\end{array}$ & $\begin{array}{l}\text { Three bicycle based MICT } \\
\text { sessions per week for } 8 \text { weeks. } \\
\text { MICT consisted of aerobic } \\
\text { training on a stationary bike or } \\
\text { treadmill (20-30 min at } 46-64 \% \\
\text { of VO2max). Each session begun } \\
\text { with a } 10 \text {-min warm-up. The } \\
\text { entire training session lasted from } \\
45-60 \text { min. }\end{array}$ \\
\hline
\end{tabular}




\begin{tabular}{|c|c|c|c|c|c|}
\hline $\begin{array}{l}\text { Chou et al., } \\
2019\end{array}$ & $\begin{array}{l}\text { Two-armed RCT. Patients } \\
\text { with HF } \\
\text { were randomised to } 12 \\
\text { weeks of HIIT or non- } \\
\text { active control. Effects of } \\
\text { exercise on mental } \\
\text { wellbeing were measured. }\end{array}$ & $\begin{array}{l}\text { HIIT }=17 ; \\
\text { Non-active } \\
\text { control=17 }\end{array}$ & $\begin{array}{l}\text { Patients diagnosed with HF (left- } \\
\text { ventricular ejection fraction (LVEF) } \\
\leqq 40 \% \text { or HF with preserved EF, i.e., } \\
\text { LVEF }>40 \% \text { with episodes of acute } \\
\text { pulmonary edema). Mean age was } \\
60.9 \pm 0.5 \text { and } 59.7 \pm 5.3 \text { years in HIIT } \\
\text { and control groups respectively and } \\
\text { mean BMI was } 26.1 \text { and } 25.1 \\
\text { respectively. }\end{array}$ & $\begin{array}{l}\text { HIIT was conducted on a bicycle ergometer thrice } \\
\text { weekly for } 12 \text { weeks. HIIT included a } 3 \text { min warm-up, } \\
\text { five 3-min intervals at } 80 \% \text { of VO2peak separated by } \\
\text { 3-min exercise at } 40 \% \text { of VO2peak, and a 3-min cool- } \\
\text { down. }\end{array}$ & $\begin{array}{l}\text { GHC patients only engaged in } \\
\text { general home-based health care, } \\
\text { as instructed by their } \\
\text { rehabilitation physicians. }\end{array}$ \\
\hline $\begin{array}{l}\text { Hurst et al., } \\
2019\end{array}$ & \begin{tabular}{|l|} 
Two-armed RCT. Older \\
adults were randomised to \\
12 weeks of HIIT or a non- \\
active control. Effects of \\
exercise on mental \\
wellbeing was measured.
\end{tabular} & $\begin{array}{l}\text { HIIT }=18, \\
\text { Non-active } \\
\text { control=18 }\end{array}$ & $\begin{array}{l}\text { Adults aged over } 50 \text { years without } \\
\text { pre-existing, neuromuscular or } \\
\text { skeletal conditions or systemic } \\
\text { disease who did not engage in } \\
\text { structured exercise more than twice } \\
\text { per week. Mean age was } 61.9 \text { (50- } \\
81 \text { ) and } 62.8(50-74) \text { years in HIIT } \\
\text { and control group respectively, } 61 \% \\
\text { and } 56 \% \text { in each group were male } \\
\text { respectively and mean BMI was } \\
28.1 \pm 4.4 \text { and } 27.4 \pm 5.3 \mathrm{~kg} / \mathrm{m} 2 \text { in } \\
\text { each group. }\end{array}$ & $\begin{array}{l}\text { Two HIIT sessions per week for } 12 \text { weeks. Each } \\
\text { session included a } 6 \text { min warm-up, four sets of high- } \\
\text { intensity exercise at }>90 \% \text { HRmax (upper- (bent over } \\
\text { row, shoulder press), lower- (squat, split squat) and } \\
\text { full-body (power clean and press, step and press, } \\
\text { pulldown to squat, high pull) exercises) and a } 4-\text { min } \\
\text { cool-down. In week } 1 \text {, repetition duration was } 45 \text {-s. } \\
\text { Each set was followed by } 3 \text { min of passive rest. } \\
\text { Repetition duration increased by } 10 \mathrm{~s} \text { at the end of } \\
\text { every third week, with duration being } 75 \text {-s by week } \\
10 \text { Total exercise duration increasing from } 12 \text { to } 20 \\
\text { min. }\end{array}$ & $\begin{array}{l}\text { Participants maintained habitual } \\
\text { physical activity. }\end{array}$ \\
\hline $\begin{array}{l}\text { Mitropoulos } \\
\text { et al., } 2018\end{array}$ & $\begin{array}{l}\text { Three-armed RCT. Patients } \\
\text { with cutaneous systemic } \\
\text { sclerosis (SSc) } \\
\text { were randomised to } 12 \\
\text { weeks of HIIT cycle } \\
\text { ergometer (HIIT-CE), HIIT } \\
\text { arm cranking ergometer } \\
\text { (HIIT-ACE) or a non-active } \\
\text { control. Effects of exercise } \\
\text { on symptoms of anxiety } \\
\text { and depression were } \\
\text { measured. }\end{array}$ & $\begin{array}{l}\text { HIIT- } \\
\text { CE }=11 ; \text { HIIT } \\
- \\
\text { ACE }=11 ; \text { No } \\
\text { n-active } \\
\text { control }=12 \\
\end{array}$ & $\begin{array}{l}\text { Patients with limited cutaneous } \\
\text { scleroderma ( } 31 \text { women, } 3 \text { men), } \\
\text { with disease duration between } 1-10 \\
\text { years. Mean age was } 69.1 \pm 9.7 \\
65.1 \pm 10 \text { and } 62.2 \pm 14.3 \text { years in } \\
\text { HIIT-ACE, HIIT-CE and control } \\
\text { groups respectively, mean BMI was } \\
25.6 \pm 4.8,24.5 \pm 3.6 \text { and } 27.3 \pm 4.0 \\
\mathrm{~kg} / \mathrm{m} 2 \text { respectively and mean illness } \\
\text { duration } 7.8 \pm 2.3,7.7 \pm 2.1 \text { and } \\
6.3 \pm 2.0 \text { in the three groups } \\
\text { respectively. }\end{array}$ & $\begin{array}{l}\text { Twice weekly HIIT sessions each week for } 12 \text { weeks. } \\
\text { Each session included a } 5 \text { min warm-up on an arm } \\
\text { crank or cycle ergometer depending on the group, } \\
\text { followed by HIIT for } 30 \mathrm{~s} \text { at } 100 \% \text { of PPO } \\
\text { interspersed by } 30 \mathrm{~s} \text { passive recovery for a total of } 30 \\
\text { min and then a } 5 \text { min cool-down. }\end{array}$ & $\begin{array}{l}\text { The control group did not perform } \\
\text { any type of physical activity. }\end{array}$ \\
\hline $\begin{array}{l}\text { Malmo et al., } \\
2016\end{array}$ & $\begin{array}{l}\text { Two-armed RCT. Patients } \\
\text { with non-permanent } \\
\text { atrial fibrallation (AF) } \\
\text { were randomised to } 12 \\
\text { weeks of HIIT or a non- } \\
\text { active control. Effects of } \\
\text { exercise on mental } \\
\text { wellbeing was measured. }\end{array}$ & $\begin{array}{l}\text { HIIT }=26 \\
\text { Non-active } \\
\text { control=25 }\end{array}$ & $\begin{array}{l}\text { Patients with symptomatic, ECG- } \\
\text { documented, nonpermanent AF. } \\
\text { Mean age was } 62 \pm 9 \text { and } 56 \pm 8 \text { years } \\
\text { in control and HIT groups } \\
\text { respectively, } 88 \% \text { and } 77 \% \text { in each } \\
\text { group were male and mean BMI was } \\
28.2 \pm 4.3 \text { and } 28.2 \pm 4.8 \text { in each group } \\
\text { respectively. }\end{array}$ & $\begin{array}{l}\text { HIIT three times weekly for } 12 \text { weeks consisting of } \\
\text { treadmill running/ walking. HIIT consisted of a 10- } \\
\text { min warm-up, four 4-min intervals at } 85-95 \% \\
\text { of HRpeak with } 3 \text { min of active recovery at } 60-70 \% \\
\text { of HRpeak between intervals, and a 5-minute } \\
\text { cooldown period. Patients were allowed to perform } 1 \\
\text { exercise per week at home, where exercise intensity } \\
\text { was documented with a heart rate monitor. }\end{array}$ & $\begin{array}{l}\text { The control group continued their } \\
\text { previous exercise habits. }\end{array}$ \\
\hline
\end{tabular}




\begin{tabular}{|c|c|c|c|c|c|}
\hline \begin{tabular}{|l} 
Conraads et \\
al., 2015
\end{tabular} & $\begin{array}{l}\text { Two-armed RCT. Patients } \\
\text { with CAD } \\
\text { were randomised to } 12 \\
\text { weeks of HIIT or aerobic } \\
\text { continuous training (ACT). } \\
\text { Effects of exercise on } \\
\text { mental wellbeing was } \\
\text { measured. }\end{array}$ & $\begin{array}{l}\mathrm{HIIT}=100 \\
\mathrm{ACT}=100\end{array}$ & \begin{tabular}{|l|} 
Patients with stable CAD $(90 \%$ \\
men). All participants had \\
angiographically documented CAD \\
or previous acute myocardial \\
infarction; left ventricular ejection \\
fraction >40\%; and were stable with \\
regard to symptoms and medication \\
for at least 4 weeks. (HIIT: age \\
$58.4 \pm 9.1$, BMI $28 \pm 4.4$; ACT: age \\
$59.9 \pm 9.2$, BMI $28.5 \pm 4.3)$.
\end{tabular} & $\begin{array}{l}\text { Bicycle based HIIT training three times weekly for } 12 \\
\text { weeks. HIIT consisted of four 4-min intervals at } 85- \\
95 \% \text { of peak HR interspered with four } 3 \text { min intervals } \\
\text { of active rest at } 50-70 \% \text { of peak. Each session begun } \\
\text { with a } 10 \text { min warm-up at } 60-70 \% \text { of HRpeak and } \\
\text { each session was } 38 \text { minutes long in total. }\end{array}$ & $\begin{array}{l}\text { Bicycle based ACT training three } \\
\text { times weekly for } 12 \text { weeks. ACT } \\
\text { consisted of a } 5 \text { min warm-up at } \\
60-70 \% \text { peak HR, } 37 \text { min of at } \\
\text { least } 70-75 \% \text { of peak HR and } 5 \\
\text { min cooldown at } 60-70 \% \text { of peak } \\
\text { HR. Total exercise time was } 47 \\
\text { mins. }\end{array}$ \\
\hline \begin{tabular}{|l|} 
Pattyn et al., \\
$2016(1$ year \\
follow-up \\
of Conraads e \\
t al., 2015)
\end{tabular} & $\begin{array}{l}\text { Follow-up of a two-armed } \\
\text { RCT. Patients with CAD } \\
\text { were randomised to } 12 \\
\text { weeks of HIIT or aerobic } \\
\text { continuous training (ACT). } \\
\text { Effects of exercise on } \\
\text { mental wellbeing was } \\
\text { measured at 1-year follow- } \\
\text { up. }\end{array}$ & $\begin{array}{l}\mathrm{HIIT}=80 \\
\mathrm{ACT}=83\end{array}$ & 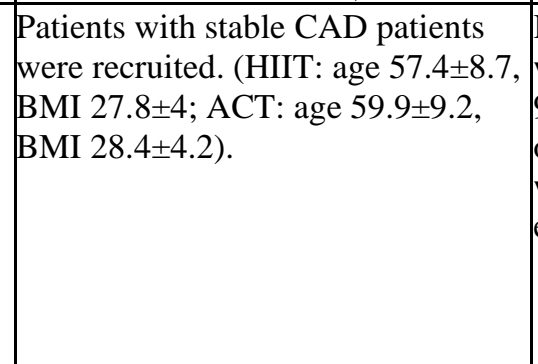 & $\begin{array}{l}\text { Bicycle based HIIT training three times weekly for } 12 \\
\text { weeks. HIIT consisted of four } 4 \text {-min intervals at } 85- \\
95 \% \text { of peak HR interspered with four } 3 \text { min intervals } \\
\text { of active rest at } 50-70 \% \text { of peak. Each session begun } \\
\text { with a } 10 \text { min warm-up at } 60-70 \% \text { of HRpeak and } \\
\text { each session was } 38 \text { minutes long in total. }\end{array}$ & $\begin{array}{l}\text { Bicycle based ACT training three } \\
\text { times weekly for } 12 \text { weeks. ACT } \\
\text { consisted of a } 5 \text { min warm-up at } \\
60-70 \% \text { peak HR, } 37 \text { min of at } \\
\text { least } 70-75 \% \text { of peak HR and } 5 \\
\text { min cooldown at } 60-70 \% \text { of peak } \\
\text { HR. Total exercise time was } 47 \\
\text { mins. }\end{array}$ \\
\hline \begin{tabular}{|l|} 
Jaureguizar e \\
t al., 2016
\end{tabular} & $\begin{array}{l}\text { Two-armed RCT. Patients } \\
\text { with CAD } \\
\text { were randomised to } 8 \\
\text { weeks of HIIT or MICT. } \\
\text { Effects of exercise on } \\
\text { mental wellbeing was } \\
\text { measured. }\end{array}$ & $\begin{array}{l}\text { HIIT }=36 ; \\
\text { MICT }=36\end{array}$ & $\begin{array}{l}\text { Patients who were diagnosed with } \\
\text { stable New York Heart Association } \\
\text { functional class I or II CAD with } \\
\text { angina pectoris or myocardial } \\
\text { infarction and no heart failure. Mean } \\
\text { age was } 58 \pm 11 \text { years in both } \\
\text { groups, } 78 \% \text { and } 92 \% \text { were male in } \\
\text { HIIT and MICT groups respectively, } \\
\text { mean BMI was } 29.6 \pm 4.4 \text { and } 29.5 \pm \\
4.1 \mathrm{~kg} / \mathrm{m} 2 \text { in both groups } \\
\text { respectively. }\end{array}$ & $\begin{array}{l}\text { Bicycle based HIIT three times weekly for } 8 \text { weeks. } \\
\text { HIIT consisted of } 20 \text {-sec repetitions at } 50 \% \text { of the } \\
\text { maximum load followed by } 40 \text {-sec recovery periods at } \\
10 \% \text {. Each session included a warm and cool-down, } \\
\text { session duration was } 40 \text { min. The exercise workload } \\
\text { applied at the peak intervals was } 104.5 \%+/-22.2 \% \\
\text { (first month) and } 134.5 \%+/-29.7 \% \text { (second month) } \\
\text { of the maximum load. }\end{array}$ & $\begin{array}{l}\text { Bicycle based MICT three times } \\
\text { weekly for } 8 \text { weeks. Patients } \\
\text { cycled continuously at a HR } \\
\text { below the HR at VT1 during the } \\
\text { first month and at VT1 plus } 10 \% \\
\text { in the second month. Session } \\
\text { duration was } 40 \text { min. The } \\
\text { intensity of exercise in the first } \\
\text { month was } 64.2 \%+/-8.5 \% \text { of } \\
\text { O2peak and } 69.5 \%+/-8.7 \% \text { in the } \\
\text { second month. }\end{array}$ \\
\hline $\begin{array}{l}\text { Karlsen et al., } \\
2017\end{array}$ & $\begin{array}{l}\text { Two-armed RCT. Obese } \\
\text { subjects with moderate-to- } \\
\text { severe obstructive } \\
\text { sleep apnoea (OSA) } \\
\text { were randomised to } 12 \\
\text { weeks of HIIT or a non- } \\
\text { active control. Effects of } \\
\text { exercise on sleep quality } \\
\text { were measured. }\end{array}$ & $\begin{array}{l}\text { HIIT }=15 ; \\
\text { Non-active } \\
\text { control=15 }\end{array}$ & $\begin{array}{l}\text { Participants with moderate-to-severe } \\
\text { OSA, a BM } \geq 30 \mathrm{~kg} / \mathrm{m} 2 \text {, and } \\
\text { an apnoea-hypopnea index score } \\
\geq 15 . \text { Mean age was } 52.5 \pm 7.4 \text { and } \\
49.9 \pm 9.7 \text { years in HIIT and control } \\
\text { groups respectively, } 31 \% \text { and } 20 \% \\
\text { were female in each group } \\
\text { respectively and mean BMI was } \\
38.5 \pm 7.0 \text { and } 37.7 \pm 4.8 \mathrm{~kg} / \mathrm{m} 2 \\
\text { respectively. }\end{array}$ & $\begin{array}{l}\text { Two HIIT sessions per week for } 12 \text { weeks. HIIT } \\
\text { consisted of } 4 \times 4 \text { min of treadmill walking or running } \\
\text { at } 90 \%-95 \% \text { of HRmax interspersed with } 3 \text { min rest } \\
\text { periods at } \sim 70 \% \text { of HRmax. Each training session } \\
\text { started with } 10 \text { min warm-up at } \sim 70 \% \text { of HRmax. }\end{array}$ & $\begin{array}{l}\text { The control group was encouraged } \\
\text { to continue their normal lifestyle. }\end{array}$ \\
\hline
\end{tabular}




\begin{tabular}{|c|c|c|c|c|c|}
\hline $\begin{array}{l}\text { Ellingsen et } \\
\text { al., } 2017\end{array}$ & $\begin{array}{l}\text { Three-armed RCT. Patients } \\
\text { with HF with reduced } \\
\text { ejection fraction } \\
\text { were randomised to } 12 \\
\text { weeks of HIIT, MICT or } \\
\text { recommendation of regular } \\
\text { exercise (RRE). Effects of } \\
\text { exercise on anxiety, } \\
\text { depression, positive and } \\
\text { negative affect was } \\
\text { measured after the } \\
\text { intervention and at 52-week } \\
\text { follow-up. }\end{array}$ & $\begin{array}{l}\text { HIIT=82; } \\
\text { MICT=73; } \\
\text { RRE=76 }\end{array}$ & $\begin{array}{l}\text { Eligible patients with symptomatic, } \\
\text { stable, pharmacologically optimally } \\
\text { treated chronic heart failure. Median } \\
\text { age was } 60 \text { years (IQR 53-70 yrs); } \\
19 \% \text { were women. Median left } \\
\text { ventricular ejection fraction at } \\
\text { baseline was } 29 \% \text { (IQR, } 24 \%-34 \% \text { ). } \\
\text { Mean BMI was } 27.6,27.5 \text { and } 27.7 \\
\text { in HIIT, MICT and RRE groups. }\end{array}$ & $\begin{array}{l}\text { Three HIIT sessions each week for } 12 \text { weeks on a } \\
\text { treadmill or bicycle. HIIT consisted of four } 4 \text {-min } \\
\text { intervals at } 90-95 \% \text { of HRmax separated by } 3 \text {-min } \\
\text { active recovery periods of moderate intensity. HIIT } \\
\text { sessions lasted } 38 \text { min including warm-up and cool- } \\
\text { down at moderate intensity. }\end{array}$ & $\begin{array}{l}\text { Three MICT sessions each week } \\
\text { for } 12 \text { weeks on a treadmill or } \\
\text { bicycle. MCT was conducted at } \\
60-70 \% \text { of HRmax for } 47 \text { mins. } \\
\text { Patients randomized to RRE were } \\
\text { advised to exercise } \\
\text { at home and attended a session of } \\
\text { moderate-intensity training at 50- } \\
70 \% \text { of HRmax every } 3 \text { weeks. }\end{array}$ \\
\hline $\begin{array}{l}\text { Lee et al., } \\
2019\end{array}$ & $\begin{array}{l}\text { Two-armed RCT. Women } \\
\text { with CAD } \\
\text { were randomised to } 24 \\
\text { weeks of HIIT or MICT. } \\
\text { Effects of exercise on } \\
\text { depressive symptoms was } \\
\text { measured. }\end{array}$ & $\begin{array}{l}\mathrm{HIIT}=17 \\
\mathrm{MICT}=14\end{array}$ & $\begin{array}{l}\text { Thirty-one postmenopausal female } \\
\text { CAD patients ( } \geq 50 \text { years of age). All } \\
\text { had documented CAD, left } \\
\text { ventricular ejection fraction }>35 \% \text {. } \\
\text { Mean age was } 69.6 \pm 5.9 \text { and } 69.3 \pm \\
9.9 \text { years in MICT and HIIT groups } \\
\text { respectively and mean BMI was } \\
28.0 \pm 5.7 \text { and } 26.6 \pm 4.2 \mathrm{~kg} / \mathrm{m} 2 \\
\text { respectively. }\end{array}$ & $\begin{array}{l}\text { One, supervised HIIT session per week and four } \\
\text { additional unsupervised home-exercise sessions per } \\
\text { week. HIIT began with } 6 \text { weeks, 'run-in' period } \\
\text { where patients performed usual care which was } \\
\text { identical to the MICT group. In the seventh week of } \\
\text { the study, patients began performing HIIT } 3 \text { days per } \\
\text { week and two usual care MICT sessions per week. } \\
\text { HIIT consisted of a 5-10min warm-up, four 4-min } \\
\text { intervals of walking/jogging at 90\%-95\% of Peak } \\
\text { HR, interspersed with } 3 \text { min of active recovery } \\
\text { performed at } ~ 50 \%-70 \% \text { of Peak HR; and a 5min } \\
\text { cool-down. }\end{array}$ & $\begin{array}{l}\text { One supervised MICT session per } \\
\text { week and four additional } \\
\text { unsupervised home-exercise } \\
\text { sessions per week. MICT } \\
\text { consisted of usual care sessions of } \\
\text { either walking or jogging on the } \\
\text { track or treadmill for } \\
\text { approximately } 30-40 \text { min, } \\
\text { performed at } 60-80 \% \text { of } \\
\text { VO2peak, in addition to a warm- } \\
\text { up and cool down period. }\end{array}$ \\
\hline $\begin{array}{l}\text { Batrakoulis e } \\
\text { t al., } 2019\end{array}$ & $\begin{array}{l}\text { Three armed RCT. Inactive } \\
\text { obese women } \\
\text { were randomised to } 10 \\
\text { months of HIIT, } 5 \text { months } \\
\text { of HIIT and } 5 \text { months of } \\
\text { detraining or a non-active } \\
\text { control. Effects of exercise } \\
\text { on psychosocial distress } \\
\text { was measured. }\end{array}$ & $\begin{array}{l}10 \text { months } \\
\text { HIIT=14; } 5 \\
\text { months HIIT } \\
+5 \text { months } \\
\text { detraining=1 } \\
4 ; \text { Non-active } \\
\text { control }=21\end{array}$ & $\begin{array}{l}\text { Premenopausal women aged } 30-45 \\
\text { years who were physically inactive } \\
\text { (sedentary for } \geq 6 \text { months before the } \\
\text { study, daily step count }<7,000 \text {, and } \\
<30 \text { min/day of moderate-to- } \\
\text { vigorous PA), overweight or obese } \\
\text { (BMI of } 25.1-34.9 \text { and body fat } \\
\geq 32 \% \text { ). (HIIT: age } 36.4 \pm 5 \text {, BMI } \\
28.2 \pm 2.8 \text {, Con: age } 36 \pm 4.2 \text {, BMI } \\
29.6 \pm 3 \text { ). }\end{array}$ & $\begin{array}{l}\text { HIIT performed three times/week consisted of a } \\
\text { hybrid format including a mix of endurance training } \\
(\mathrm{ET}) \text {, core strengthening and RT elements, performed } \\
\text { in a circuit fashion using } 20-40 \text { sec of effort and } \\
\text { recovery interval and a 10-min warm-up and 5-min } \\
\text { cool-down. There was a rise in intensity. Mean HR as } \\
\% \text { of HRmax reached } 72.5 \% \text { in weeks } 1-7,79.7 \% \text {, in } \\
\text { weeks } 8-14,87.0 \% \text { in weeks } 15-20,87.5 \% \text { in week } \\
21 \text {. During the first } 5 \text { months, both HIIT groups } \\
\text { performed HIIT. In months } 6-10 \text {, one group } \\
\text { continued the exercise protocol whereas the other } \\
\text { abstained from training. }\end{array}$ & $\begin{array}{l}\text { Control participants did not } \\
\text { participate in training. }\end{array}$ \\
\hline $\begin{array}{l}\text { Yardley et } \\
\text { al., } 2017\end{array}$ & \begin{tabular}{|l|} 
Follow-up of a two \\
armed RCT. Heart \\
transplant (HTx) recipients \\
were randomized to a one- \\
year HIIT program or usual \\
care. Effects of exercise on \\
symptoms of anxiety and
\end{tabular} & $\begin{array}{l}\text { HIIT }=26 ; \\
\text { Non-active } \\
\text { control }=26\end{array}$ & \begin{tabular}{|l|} 
Patients with clinically \\
stable HTx and aged $>18$ years; $1-8$ \\
years after HTx and receiving \\
optimal medical treatment. Mean \\
age was $48 \pm 17$ and $53 \pm 14$ years in \\
HIIT and control groups \\
respectively, $67 \%$ and $71 \%$ were \\
male in each group and time
\end{tabular} & $\begin{array}{l}\text { HIIT was performed on a treadmill. HIIT was divided } \\
\text { into three } 8 \text {-week periods of exercise with three } \\
\text { sessions every week. Additionally, the patients were } \\
\text { encouraged to continue any physical activity on their } \\
\text { own. The HIIT-sessions consisted of a } 10 \text { min warm- } \\
\text { up, followed by four } 4 \text { min exercise bouts at } 85-95 \% \\
\text { of HRmax, interposed by } 3 \text { min active recovery } \\
\text { periods corresponding to } \sim 11-13 \text { on the Borg. }\end{array}$ & $\begin{array}{l}\text { The control group received basic, } \\
\text { general care given to } \\
\text { all HTx patients. }\end{array}$ \\
\hline
\end{tabular}




\begin{tabular}{|c|c|c|c|c|c|}
\hline & $\begin{array}{l}\text { depression were measured } \\
\text { at 5-year follow-up. }\end{array}$ & & $\begin{array}{l}\text { after HTx was } 4.3 \pm 2.4 \text { and } 3.8 \pm \\
2.1 \text { in each group respectively and } \\
\text { mean BMI was } 27.73 \pm 5.73 \text { and } \\
28.9 \pm 6.74 \text {. }\end{array}$ & & \\
\hline $\begin{array}{l}\text { Leahy et al., } \\
2018\end{array}$ & $\begin{array}{l}\text { Two armed feasibility } \\
\text { RCT. Adolescents } \\
\text { were randomised to } 14 \\
\text { weeks of HIIT or a wait-list } \\
\text { control. Effects of exercise } \\
\text { on psychological distress } \\
\text { and subjective stress were } \\
\text { measured. }\end{array}$ & $\begin{array}{l}\text { HIIT }=38 \\
\text { Waist-list } \\
\text { control=30 }\end{array}$ & $\begin{array}{l}\text { Sixty-eight participants ( } 37 \text { males, } \\
31 \text { females) from Grade } 11 \text { from two } \\
\text { consenting secondary schools. Mean } \\
\text { age was } 16.2 \pm 0.4 \text { in each group and } \\
\text { mean BMI was } 21.7 \pm 3.1 \text { and } 22.8 \pm \\
2.8 \text { in HIIT and control groups. }\end{array}$ & $\begin{array}{l}\text { Three HIIT sessions per week for } 14 \text { weeks. HIIT } \\
\text { sessions comprised of a 2-min warm-up, followed by } \\
8-16 \text { min of HIIT, and a 2-min cool-down. HIIT } \\
\text { workouts included a combination of aerobic- (e.g., } \\
\text { shuttle runs) and resistance- (e.g., push-ups) exercises. } \\
\text { Participants were able to select from the following } \\
\text { workouts: Gym HIIT, Sport HIIT, Class HIIT, Dance } \\
\text { HIIT, Combat HIIT and Brain HIIT. HIIT consists of } \\
30 \text { second bouts at }>85 \% \text { HRmax interspersed with } 30 \\
\text { seconds of rest. }\end{array}$ & $\begin{array}{l}\text { The wait-list control group } \\
\text { participated in usual school } \\
\text { activities and received the } \\
\text { intervention following the posttest } \\
\text { assessment period. }\end{array}$ \\
\hline $\begin{array}{l}\text { Stavrinou et } \\
\text { al., } 2018\end{array}$ & $\begin{array}{l}\text { Three armed RCT. Healthy } \\
\text { inactive adults } \\
\text { were randomised to HIIT } \\
\text { twice weekly for } 8 \text { weeks, } \\
\text { HIIT thrice weekly for } 8 \\
\text { weeks or a non-active } \\
\text { control. Effects of exercise } \\
\text { on mental wellbeing was } \\
\text { measured. }\end{array}$ & $\begin{array}{l}\text { HIIT-2=14; } \\
\text { HIIT }=3=13 ; \\
\text { Non-active } \\
\text { control=8 }\end{array}$ & $\begin{array}{l}\text { Inactive healthy adults, none were } \\
\text { smokers and none had any } \\
\text { diagnosed metabolic or } \\
\text { cardiovascular diseases. (HIIT-3: } \\
\text { age } 31.9 \pm 2.4, \text { BMI } 21.7 \pm 3.1 ; \text { HIIT- } \\
\text { 2: age } 31.5 \pm 3.5 \text {, BMI } 23.6 \pm 4.6 ; \\
\text { Con: age } 31.7 \pm 0.8, \text { BMI } 23.4 \pm 3.1 \text { ) }\end{array}$ & $\begin{array}{l}\text { Participants in both HIIT groups undertook a 3-week } \\
\text { familiarization period consisting of three moderate-to- } \\
\text { high intensity interval training sessions. Afterwards, } \\
\text { the HIIT- } 2 \text { and HIIT-3 intervention groups trained } \\
\text { two and three times per week respectively, on a } \\
\text { cycle ergomteres, for } 8 \text { weeks. Each HIIT session } \\
\text { consisted of a } 3 \text {-min warm-up, } 10 \text { x } 60 \text {-s cycling } \\
\text { intervals at } \sim 83 \% \text { of Wpeak interspersed with } 60 \text { s of } \\
\text { low intensity exercise at } \sim 30 \% \text { Wpeak at } 50 \text { rpm, and } \\
\text { 2-min cool-down. }\end{array}$ & $\begin{array}{l}\text { Participants in the control group } \\
\text { continued their usual daily } \\
\text { activities. }\end{array}$ \\
\hline $\begin{array}{l}\text { imenez- } \\
\text { Garcia et al., } \\
2019\end{array}$ & $\begin{array}{l}\text { Three armed RCT. Older } \\
\text { adults were randomised to } \\
12 \text { weeks of HIIT, } \\
\text { moderate intensity interval } \\
\text { training (MIIT) or a non- } \\
\text { active control. Effects of } \\
\text { exercise on mental } \\
\text { wellbeing was measured. }\end{array}$ & $\begin{array}{l}\text { HIIT=28; MI } \\
\text { IT=27; Non- } \\
\text { active } \\
\text { control }=27\end{array}$ & $\begin{array}{l}\text { Community-dwelling older adults } \\
\text { aged over } 60 \text { years, none had } \\
\text { psychiatric, neurological or systemic } \\
\text { diseases. (HIIT: age } 68.23 \pm 2.97, \\
\text { BMI } 29.82 \pm 3.17 \text {; MIIT: age } \\
68.75 \pm 5.98 \text {, BMI } 30.33 \pm 3.07 \text {; Con: } \\
\text { age } 68.52 \pm 6.33 \text {, BMI } 32.13 \pm 2.3 \text { ). }\end{array}$ & $\begin{array}{l}\text { Suspension training (TRX) HIIT twice a week for } 12 \\
\text { weeks. Before the intervention, participants of the } \\
\text { HIIT and MIIT groups performed a 4-week } \\
\text { familiarization period consisting of } 2 \text { session/week } \\
\text { with video demonstrations and } 6 \text { repetition practice } \\
\text { trial. Afterwards, HIIT consisted of a } 10 \text {-min warm- } \\
\text { up, main squat activity with suspension system } \\
\text { divided into four 4-min intervals at an intensity of } 90- \\
95 \% \text { of HRmax interspersed with 3-min active rest } \\
\text { intervals at 50-70\% (25min), and a 10-min cool- } \\
\text { down. }\end{array}$ & $\begin{array}{l}\text { The MIIT group received } 2 \\
\text { sessions per week of TRX for } 12 \\
\text { weeks after the familiarization } \\
\text { period. MIIT participants } \\
\text { followed the same protocol that } \\
\text { HIIT group, but intensities were } \\
\text { lower: } 70 \% \text { and } 50 \% \text { of HRmax } \\
\text { for the main squat activity and the } \\
\text { active rest intervals respectively. } \\
\text { The non-active control group } \\
\text { maintained their daily lifestyle } \\
\text { and received a series of guidelines } \\
\text { to encourage physical activity. }\end{array}$ \\
\hline
\end{tabular}




\begin{tabular}{|c|c|c|c|c|c|}
\hline $\begin{array}{l}\text { Cheema et } \\
\text { al., } 2015\end{array}$ & \begin{tabular}{|l|} 
Two armed pilot RCT. \\
Adults with abdominal \\
obesity were randomised to \\
12 weeks of boxing HIIT or \\
MICT. Effects of exercise \\
on mental wellbeing was \\
measured.
\end{tabular} & $\begin{array}{l}\text { HIT }=6 ; \\
\text { MICT=6 }\end{array}$ & $\begin{array}{l}\text { All participants were aged }>18 \\
\text { years; had a BMI }>25 \mathrm{~kg} / \mathrm{m} 2 \text {; had } \\
\text { waist circumference }>94 \mathrm{~cm} \text { in men } \\
\text { and }>80 \mathrm{~cm} \text { in women. The cohort } \\
\text { ranged in age from } 19 \text { to } 72 \text { years } \\
\text { (mean age } 43 \pm 19 \text { and } 36 \pm 15 \text { years } \\
\text { in HIIT and MICT groups } \\
\text { respectively, BMI ranged from } 26.4 \\
\text { to } 40.3 \mathrm{~kg} / \mathrm{m} 2 \text { (HIIT mean: } 32 \pm 5.9 \text {, } \\
\text { MICT } 30.8 \pm 2.6 \text { ). }\end{array}$ & $\begin{array}{l}\text { HIIT boxing four times per week for } 12 \text { weeks. Each } \\
\text { session lasted for } 50 \text { min and included a } 5 \text { min warm- } \\
\text { up followed by three 2-min intervals (at } 86-89 \% \\
\text { HRmax) of each of the following five exercises: (1) } \\
\text { heavy bag, (2) focus mitts, (3) circular body bag, (4) } \\
\text { footwork drills, and (4) skipping interspersed with } 1 \\
\text { min of rest between intervals. }\end{array}$ & $\begin{array}{l}\text { Four, 50-min sessions of brisk } \\
\text { walking per week for } 12 \text { weeks. } \\
\text { Participants were instructed to } \\
\text { begin each session with a 5-min } \\
\text { gradual warm-up and walk as } \\
\text { quickly as possible for the } \\
\text { remainder of the session. Mean } \\
\text { HR ranged from } 64-77 \% \text { of } \\
\text { HRmax. }\end{array}$ \\
\hline $\begin{array}{l}\text { Koufaki et } \\
\text { al., } 2014\end{array}$ & $\begin{array}{l}\text { Two armed feasibility } \\
\text { RCT. } \\
\text { Patients With Chronic HF } \\
\text { were randomised to } 24 \\
\text { weeks of MICT or HIIT. } \\
\text { Effects of exercise on } \\
\text { mental wellbeing was } \\
\text { measured. }\end{array}$ & $\begin{array}{l}\text { HIIT=8; } \\
\text { MICT }=9\end{array}$ & 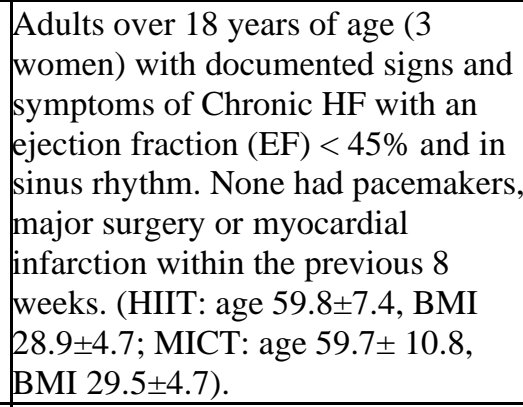 & $\begin{array}{l}\text { Three bicycle based HIIT sessions per week for } 24 \\
\text { weeks. HIIT consisted of } 2 \times 15 \text { min bouts of } \\
\text { cycling, comprising low intensity cycling phases of } 1 \\
\text { min at } 25-40 \text { watts (equivalent to } 20-30 \% \text { of PPO) } \\
\text { followed by high intensity cycling for } 30 \text { s at } 50 \% \text { of } \\
\text { the maximum workload (equivalent to } \sim 100 \% \text { of } \\
\text { PPO). }\end{array}$ & $\begin{array}{l}\text { Three bicycle based MICT } \\
\text { sessions per week for } 24 \text { weeks. } \\
\text { Patients cycled at } 90 \% \text { of their } \\
\text { predetermined VT (corresponding } \\
\text { to } 40-60 \% \text { of VO2peak). Exercise } \\
\text { stimulus progressed from } 3 \\
\text { separate bouts of cycling of } 7-10 \\
\text { min in duration, to a single } 40 \text { min } \\
\text { of continuous cycling bout by } 5-6 \\
\text { months. }\end{array}$ \\
\hline $\begin{array}{l}\text { Svensson et } \\
\text { al., } 2017\end{array}$ & $\begin{array}{l}\text { Three armed RCT. People } \\
\text { classified as obese } \\
\text { were randomised to } 16 \\
\text { weeks of HIIT, moderate } \\
\text { intensity training (MIT) or } \\
\text { a non-active control. } \\
\text { Effects of exercise on } \\
\text { mental wellbeing was } \\
\text { measured. }\end{array}$ & $\begin{array}{l}\text { HIIT=49; MI } \\
\text { T=39; Non- } \\
\text { active } \\
\text { control=22 }\end{array}$ & $\begin{array}{l}\text { Healthy, inactive individuals with a } \\
\text { BMI >35 kg/m2 and one or more } \\
\text { risk factors for ailments such as type } \\
\text { II diabetes, hypertonia } \\
\text { and/or hyperlipidaemia. Mean age } \\
\text { was } 43.6 \pm 8.3,47 \pm 10.3 \text { and } 47.4 \pm \\
9.1 \text { in HIIT, MIT and control groups } \\
\text { respectively and mean BMI was } \\
41.6 \pm 5.2,43.1 \pm 7.6 \text { and } 44.7 \pm 7.1 \\
\text { respectively. }\end{array}$ & $\begin{array}{l}\text { Three one-hour HIIT sessions per week for } 16 \text { weeks. } \\
\text { HIIT was carried out at } 85-95 \% \text { of HRmax. The } \\
\text { training in both HIIT and MIT groups was performed } \\
\text { with an interval length of } 6 \text { min for aerobic exercise } \\
\text { using cycle ergometers, syncro machines, rowing } \\
\text { machines or treadmills, and } 2 \text { min for strength- } \\
\text { endurance exercise using arm, leg, and trunk } \\
\text { machines. There was a } 30 \text {-s pause in-between each } \\
\text { bout. }\end{array}$ & $\begin{array}{l}\text { The MIT group were supervised } \\
\text { for } 30 \text { min, } 3 \text { times/week, and } \\
\text { were also recommended to } \\
\text { exercise an additional } 3 \text { times a } \\
\text { week on their own, with a } \\
\text { recommended intensity of } 40- \\
55 \% \text { of HRmax, following the } \\
\text { same regime as the HIIT group. } \\
\text { The actual exercised intensities in } \\
\text { the MIT supervised training } \\
\text { session were } 76-85 \% \text { of HRmax. } \\
\text { The non-active control group } \\
\text { received no intervention. }\end{array}$ \\
\hline $\begin{array}{l}\text { Tew et al., } \\
2017\end{array}$ & \begin{tabular}{|l|} 
Two armed feasibility \\
RCT. Patients awaiting \\
elective abdominal aortic \\
aneurysm (AAA) repair \\
were randomised to 4 \\
weeks of HIIT or usual \\
care. Effects of exercise on \\
mental wellbeing was \\
measured at end of \\
intervention and 12 weeks \\
post discharge.
\end{tabular} & $\begin{array}{l}\text { HIIT=27; } \\
\text { Usual } \\
\text { care }=26\end{array}$ & $\begin{array}{l}\text { Patients aged at least } 18 \text { years who } \\
\text { had been listed for an open or } \\
\text { endovascular repair of an infrarenal } \\
\text { AAA with a diameter of } 5 \cdot 5-7 \cdot 0 \mathrm{~cm} \text {. } \\
\text { Mean age was } 74 \cdot 6 \pm 5 \cdot 5 \text { and } 74 \cdot 9 \pm \\
6 \cdot 4 \text { in HIIT and control groups } \\
\text { respectively, BMI was } 26 \cdot 5 \pm 4 \cdot 1 \\
\text { and } 26 \cdot 8 \pm 3 \cdot 4 \text { respectively and } \\
\text { AAA diameter was } 6 \cdot 0 \pm 0 \cdot 4 \text { and } \\
5 \cdot 8 \pm 0 \cdot 4 \text { respectively. }\end{array}$ & $\begin{array}{l}\text { Three bicycle based HIIT sessions each week for } 4 \\
\text { weeks. Each of the first three sessions comprised a } \\
10 \text {-min warm-up, eight } 2 \text {-min intervals of high- } \\
\text { intensity cycling (performed at the power output } \\
\text { corresponding to anaerobic threshold on a baseline } \\
\text { cardiopulmonary exercise test) interspersed with 2- } \\
\text { min rest periods of unloaded cycling, and a 5-min } \\
\text { cool-down. In subsequent sessions, participants had } \\
\text { the choice of performing eight } 2 \text {-min or four } 4 \text {-min } \\
\text { high intensity intervals (power output guided by } \\
\text { participants' ratings of perceived exertion (RPE) } \\
\text { (RPE-L or RPE-C of } 5 \text { and } 7 \text { respectively). }\end{array}$ & $\begin{array}{l}\text { Usual care comprised evidence- } \\
\text { based medical optimization. }\end{array}$ \\
\hline
\end{tabular}




\begin{tabular}{|c|c|c|c|c|c|}
\hline $\begin{array}{l}\text { Stensvold et } \\
\text { al., } 2010\end{array}$ & $\begin{array}{l}\text { Four-armed RCT. People } \\
\text { with MetS were randomise } \\
\text { d to } 12 \text { weeks of HIIT, } \\
\text { strength training (ST), HIIT } \\
+ \text { ST or a non-active } \\
\text { control. Effects of exercise } \\
\text { on mental wellbeing was } \\
\text { measured. }\end{array}$ & $\begin{array}{l}\text { HIIT=11; } \\
\text { ST=11; HIIT } \\
+\mathrm{ST}=10 ; \\
\text { Non-active } \\
\text { control=11 }\end{array}$ & 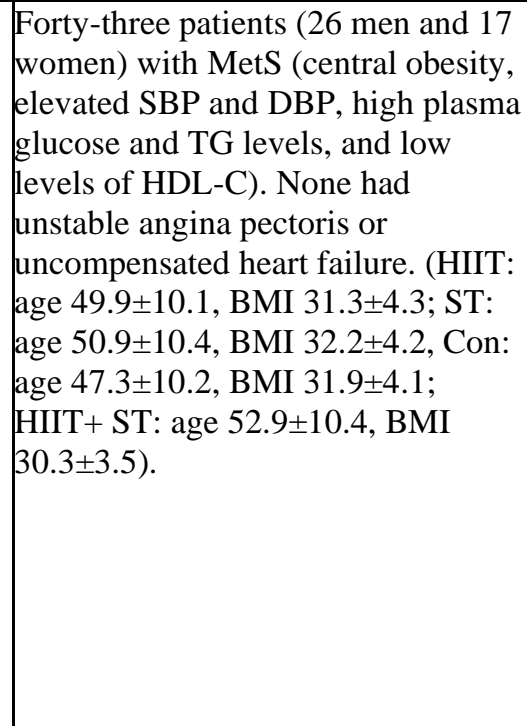 & $\begin{array}{l}\text { Three treadmill based HIIT sessions each week for } 12 \\
\text { weeks. HIIT included a } 10 \text {-min warm-up at } 70 \% \\
\text { of HRpeak, four intervals of } 4 \text { min at } 90-95 \% \\
\text { of HRpeak interspersed with } 3 \text {-mins of active } \\
\text { recovery at } 70 \% \text { of HRpeak, a 5-min cooldown } \\
\text { period. Total exercise time was } 43 \text { min. }\end{array}$ & $\begin{array}{l}\text { ST was performed three times per } \\
\text { week for } 12 \text { weeks for } 40-50 \text { min. } \\
\text { During the first week of training, } \\
\text { the resistance was set at } 60 \% \text { of } \\
\text { each individual's 1-RM. After the } \\
\text { first week, the resistance training } \\
\text { program consisted of three sets at } \\
80 \% \text { of 1-RM. ST included low } \\
\text { row, bench press, hack lift, lateral } \\
\text { raise exercise, triceps pulldown, } \\
\text { biceps curl, and low-row and core } \\
\text { exercises. The HIIT + ST group } \\
\text { performed HIIT twice a week and } \\
\text { ST once a week. The non-active } \\
\text { control group was instructed not } \\
\text { to change their dietary patterns or } \\
\text { physical activity levels during the } \\
\text { study period. }\end{array}$ \\
\hline $\begin{array}{l}\text { Lunt et al., } \\
2014\end{array}$ & $\begin{array}{l}\text { Three-armed feasibility } \\
\text { RCT. Overweight inactive } \\
\text { adults were randomised to } \\
12 \text { weeks of aerobic } \\
\text { interval training (AIT), } \\
\text { maximal volitional interval } \\
\text { training (MVIT) or an } \\
\text { active control group } \\
\text { undertaking walking-based } \\
\text { exercise (WALK). Effects } \\
\text { of exercise on mental } \\
\text { wellbeing was measured. }\end{array}$ & $\begin{array}{l}\text { AIT }=16 ; \\
\text { MVIT }=16 ; \\
\text { WALK }=17\end{array}$ & $\begin{array}{l}\text { Adults aged } 35-60 \text { years, with a } \\
\text { BMI } 28-40 \mathrm{~kg} / \mathrm{m} 2 \text {, and partaking in } \\
\text { less than } 2 \times 30 \text { minutes of moderate } \\
\text { intensity physical activity each } \\
\text { week, with no major health } \\
\text { problems. (AIT: age } 48.2 \pm 5.6, \text { BMI } \\
32.1 \pm 3.1 \text {; MVIT: age } 50.3 \pm 8, \text { BMI } \\
32.4 \pm 2.9 \text {; WALK: age } 46.3 \pm 5.4, \\
\text { BMI } 32.7 \pm 3.4) \text {. }\end{array}$ & $\begin{array}{l}\text { Three sessions of AIT or MVIT per week for } 12 \\
\text { weeks. AIT involved } 4 \text { min bouts ( } 85-95 \% \text { HRmax) } \\
\text { of fast walking or jogging, interspersed by } 3 \text { min } \\
\text { walking bouts. MVIT involved } 30 \text { sec repetitions of } \\
\text { volitional maximal 'all-out' walking or jogging up a } \\
\text { slope, interspersed with recovery periods of } 4 \text { min } \\
\text { walking. Initially participants undertook } 3 \text { repetitions } \\
\text { but aimed for up to } 6 \text { repetitions of } 45 \text { seconds of } \\
\text { maximal volitional activity. Session length was } 40 \mathrm{~min} \\
\text { for AIT and } 24.5-40 \text { min for MVIT including a } 10 \mathrm{~min} \\
\text { warm-up and } 5 \text { min cool down. }\end{array}$ & $\begin{array}{l}\text { Three sessions of WALK per } \\
\text { week for } 12 \text { weeks. WALK was a } \\
\text { walking-based prescription of a } 33 \\
\text { min walk which aimed to achieve } \\
\text { a HR of } 65-75 \% \text { HRmax. Total } \\
\text { session length was } 48 \text { min } \\
\text { including a } 10 \text { min warm-up and } \\
\text { 5min cool down. }\end{array}$ \\
\hline
\end{tabular}

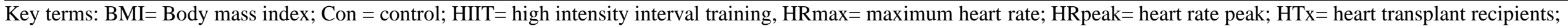
$\mathrm{MICT}=$ moderate intensity continuous training; $\mathrm{SIT}=$ sprint interval training; $\mathrm{RCT}=$ randomised controlled trial; $\mathrm{QoL}=$ quality of life; Wpeak= peak workload

Table Two- Mental health findings, adherence and adverse events

\begin{tabular}{|c|c|c|c|c|c|c|}
\hline Study & $\begin{array}{l}\text { Outcome } \\
\text { Measurement } \\
\text { Tool }\end{array}$ & $\begin{array}{l}\text { Is Mental } \\
\text { health a } \\
\text { primary or } \\
\text { secondary } \\
\text { analysis? }\end{array}$ & Outcomes & Adverse Events & Attendance & Conclusions \\
\hline $\begin{array}{l}\text { Lucibello et } \\
\text { al., } 2020\end{array}$ & \begin{tabular}{|l|}
21 -item Beck \\
Anxiety \\
Inventory (BAI); \\
21-item Beck \\
Depression
\end{tabular} & $\begin{array}{l}\text { Primary } \\
\text { outcome. }\end{array}$ & $\begin{array}{l}\text { Anxiety and depressive symptoms decreased over the } \\
\text { course of the intervention for both HIIT and control } \\
\text { groups [main effect of time: anxiety: } \mathrm{p}<.001, \eta \mathrm{p} 2= \\
0.51 \text {; depression: } \mathrm{p}<.001, \eta \mathrm{p} 2=0.41] \text {. There was no } \\
\text { group by time interaction }(\mathrm{p}>.05) \text {. }\end{array}$ & $\begin{array}{l}\text { Adverse events not } \\
\text { reported. }\end{array}$ & $\begin{array}{l}\text { Forty-six participants completed the } \\
\text { study (HIIT=25; control }=21) \text {. HIIT } \\
\text { adherence was } 99.7 \%, \text { with } 23 \text { of } 25 \\
\text { participants attending all } 27 \\
\text { sessions. }\end{array}$ & $\begin{array}{l}\text { Nine weeks of HIIT } \\
\text { may not alter indicators } \\
\text { of anxiety and } \\
\text { depression in young } \\
\text { adults. }\end{array}$ \\
\hline
\end{tabular}




\begin{tabular}{|c|c|c|c|c|c|c|}
\hline & $\begin{array}{l}\text { Inventory-II } \\
\text { (BDI-II) }\end{array}$ & & & & & \\
\hline \begin{tabular}{|l|} 
Nytroen et \\
al., 2019
\end{tabular} & \begin{tabular}{l|l} 
Hospital Anxiety \\
and Depression \\
Scale (HADS); \\
Mental \\
Component \\
Summary (MCS) \\
of the Short \\
Form-36 QoL \\
scale
\end{tabular} & $\begin{array}{l}\text { Secondary } \\
\text { outcome. }\end{array}$ & $\begin{array}{l}\text { Anxiety and Depression scores were low in both } \\
\text { groups at both time points. There was no significant } \\
\text { difference in anxiety and depression scores nor mental } \\
\text { wellbeing between the groups and no group by time } \\
\text { interaction (Anxiety: MD -0.4 [95\%CI - } 1.8 ; 0.9] \text {, } \\
\text { p=0.529; Depression: MD -0.2 [95\%CI -1.4; } 1.0] \\
\text { p=0.741; MCS: MD 3 [95\%CI -2;9], p=0.170). }\end{array}$ & $\begin{array}{l}\text { No serious exercise- } \\
\text { related adverse event } \\
\text { occurred in either } \\
\text { group. The intervention } \\
\text { could not be completed } \\
\text { at } 100 \% \text { every week by } \\
\text { all participants because } \\
\text { some inactive periods } \\
\text { occurred as a result of } \\
\text { lung infections, cardiac } \\
\text { events, musculoskeletal } \\
\text { problems, } \\
\text { hospitalizations related } \\
\text { to outstanding } \\
\text { conditions. }\end{array}$ & $\begin{array}{l}\text { Eighty-one participants were tested } \\
\text { at baseline, and } 3 \text { dropped out } \\
\text { during the intervention ( } 78 \text { patients } \\
\text { completed the } 1 \text {-year follow-up: } 37 \\
\text { in the HIIT group and } 41 \text { in the } \\
\text { MICT group). Of the initially } \\
\text { planned sessions, } 81 \% \text { were } \\
\text { accomplished in both groups. }\end{array}$ & $\begin{array}{l}\text { Nine months of HIIT } \\
\text { may not alter indicators } \\
\text { of anxiety, depression } \\
\text { and mental wellbeing } \\
\text { in HTx recipients. }\end{array}$ \\
\hline $\begin{array}{l}\text { Rolid et al., } \\
2020(3- \\
\text { year follow- } \\
\text { up } \\
\text { of Nytroen } \\
\text { et al., } \\
2019)\end{array}$ & \begin{tabular}{l|l} 
Hospital Anxiety \\
and Depression \\
Scale (HADS); \\
Mental \\
Component \\
Summary (MCS) \\
of the Short \\
Form-36 QoL \\
scale
\end{tabular} & $\begin{array}{l}\text { Secondary } \\
\text { outcome. }\end{array}$ & $\begin{array}{l}\text { Mental health scores remained high and stable during } \\
\text { the 3-year follow-up (HIIT baseline: median [IQR] } 59 \\
\text { (13), 3-year: } 56 \text { (10); MICT baseline: 56 (10), 3-year: } \\
57 \text { (12). The between-group differences from baseline } \\
\text { to the 3-year follow-up for both HADS-A and HADS- } \\
\text { D were not significant (HADS-A: HIIT baseline: } \\
\text { median [IQR] 2.0 (4.0), 3-year 4.0 (4.0); MICT } \\
\text { baseline: 3.0 (3.0), 3-year 3.0 (5.0); HADS-D: HIIT } \\
\text { baseline: 2.0 (4.0), 3-year 2.0 (5.0), MICT baseline: } \\
1.0(1.3), 3 \text {-year 1.0 (3.0)). }\end{array}$ & $\begin{array}{l}\text { No serious exercise- } \\
\text { related adverse event } \\
\text { occurred in either } \\
\text { group. }\end{array}$ & $\begin{array}{l}\text { Twenty-eight HIIT participants and } \\
34 \text { MICT participants completed the } \\
3 \text { year-follow-up. }\end{array}$ & $\begin{array}{l}\text { Nine months of HIIT } \\
\text { may not alter indicators } \\
\text { of anxiety, depression } \\
\text { and mental wellbeing } \\
\text { in Hxz recipients at 3- } \\
\text { year follow-up. }\end{array}$ \\
\hline $\begin{array}{l}\text { Allen et al., } \\
2018\end{array}$ & \begin{tabular}{l|} 
Centers for \\
Epidemiologic \\
Study - \\
Depression Scale \\
(CESD); \\
Positive and \\
Negative Affect \\
Scale (PANAS); \\
Perceived Stress \\
Scale (PSS)
\end{tabular} & $\begin{array}{l}\text { Secondary } \\
\text { outcome. }\end{array}$ & $\begin{array}{l}\text { There was no change in depression, perceived stress } \\
\text { or negative affect over the course of the intervention } \\
\text { and no between-group differences (depression: HIIT } \\
\text { mean change }+0.50 \pm 1.09 ; \mathrm{CA}+4.00 \pm 3.05 ; \text { Con } \\
+1.50 \pm 0.93, \mathrm{p} \text {-value } 2=0.6307 ; \text { Negative Affect: HIIT } \\
\text { mean change }+0.63 \pm 1.08 ; \mathrm{CA}+1.60 \pm 1.78, \text { Con } \\
-0.10 \pm 1.68, \mathrm{p} \text {-value } 2=0.7160 ; \text { Stress: HIIT mean } \\
\text { change }+2.75 \pm 1.16 ; \mathrm{CA}+1.60 \pm 2.94 ; \text { Con }+2.90 \pm \\
2.10 \text { p-value } 2=0.5889) \text {. There were significant } \\
\text { differences regarding change in positive affect } \\
\text { between groups }(\text { HIIT mean change }+2.88 \pm 1.39 ; \\
\text { CA: }+4.40 \pm 2.06 ; \text { Con }-2.70 \pm 1.56 ; \mathrm{p}- \\
\text { value } 2=0.0197) \text {. }\end{array}$ & \begin{tabular}{|l|} 
A total of 20 adverse \\
events were reported of \\
which 19 were \\
unrelated to the study \\
(cold/flu), with one \\
deemed possibly related \\
(low back pain in a CA \\
participant).
\end{tabular} & $\begin{array}{l}\text { Seven participants completed the } \\
\text { HIIT intervention, } 5 \text { completed the } \\
\text { CA intervention and } 10 \text { remained in } \\
\text { the control group at } 12 \text {-weeks. } \\
\text { Approximately half of the personal } \\
\text { trainer sessions were attended in } \\
\text { both the HIIT ( } 52 \pm 9 \%) \text { and CA } \\
(49 \pm 13 \%) \text { groups. }\end{array}$ & \begin{tabular}{|l|} 
Twelve weeks of \\
exercise may improve \\
positive affect in adult \\
smokers, although \\
greater effects were \\
seen following CA \\
compared to HIIT. No \\
changes in depression, \\
stress or negative affect \\
were observed.
\end{tabular} \\
\hline
\end{tabular}




\begin{tabular}{|c|c|c|c|c|c|c|}
\hline $\begin{array}{l}\text { May et al., } \\
2019\end{array}$ & \begin{tabular}{|l|} 
enter for \\
Epidemiologic \\
Studies \\
Depression Scale \\
(CES-D); State- \\
Trait Anxiety \\
Inventory \\
(STAI) \\
\end{tabular} & $\begin{array}{l}\text { Secondary } \\
\text { outcome. }\end{array}$ & $\begin{array}{l}\text { There was no pre-post intervention by experimental } \\
\text { condition interactions for depressive or anxiety scores } \\
\text { (Depression: HIIT pre } 16.94 \pm 1.02 \text {, post } 15.38 \pm 0.91 \text {; } \\
\text { HRVCB pre } 14.46 \pm 1.01, \text { post } 13.00 \pm 1.13 \text {; Con pre } \\
16.01 \pm 1.07 \text {, post } 16.45 \pm 1.01 \text {; Anxiety: HIIT pre } \\
17.38 \pm 1.33 \text {, post } 16.63 \pm 1.03 \text {, HRVCB pre } \\
17.39 \pm 1.48 \text {, post } 16.54 \pm 1.14 \text {; Con pre } 17.22 \pm 1.34 \\
16.02 \pm 1.11 \text { ). }\end{array}$ & $\begin{array}{l}\text { Adverse events not } \\
\text { reported. }\end{array}$ & Attendance not reported. & $\begin{array}{l}\text { Four weeks of HIIT } \\
\text { may not elicit changes } \\
\text { in depression and } \\
\text { anxiety in college } \\
\text { students. }\end{array}$ \\
\hline $\begin{array}{l}\text { Krawcyk et } \\
\text { al., } 2019\end{array}$ & \begin{tabular}{|l|} 
Major \\
Depression \\
Inventory \\
(MDI); World \\
Health \\
Organization- \\
Five Well-being \\
Index (WHO-5) \\
questionnaire \\
(mental \\
wellbeing)
\end{tabular} & $\begin{array}{l}\text { Secondary } \\
\text { outcome. }\end{array}$ & $\begin{array}{l}\text { No change was detected between groups for } \\
\text { depression nor mental well-being (WB: MD }-0.6 \\
{[95 \% \text { CI: }-7.7 ; 6.5, p=0.86 \text {; depression HIIT median }} \\
{[\text { IQR] pre: } 5[1 ; 10] \text {, post } 6[3 ; 13] \text {; Con pre: } 9[4 ; 12] \text {, }} \\
\text { post } 7[4 ; 15], p=0.086 \text { ). }\end{array}$ & $\begin{array}{l}\text { No adverse events } \\
\text { related to the } \\
\text { intervention were } \\
\text { recorded. }\end{array}$ & $\begin{array}{l}\text { Thirty-one participants completed } \\
\text { the HIIT intervention and } 32 \\
\text { completed usual care follow-up. }\end{array}$ & $\begin{array}{l}\text { Twelve weeks of HIIT } \\
\text { may not elicit changes } \\
\text { in depression and } \\
\text { mental wellbeing in } \\
\text { patients with Lacunar } \\
\text { stroke. }\end{array}$ \\
\hline $\begin{array}{l}\text { Adams et } \\
\text { al., } 2018\end{array}$ & \begin{tabular}{|l|} 
Center for \\
Epidemiologic \\
Studies \\
Depression Scale \\
10 -item \\
inventory; \\
Spielberger State \\
Anxiety Scale \\
10 -item \\
inventory; \\
Pittsburgh Sleep \\
Quality Index; \\
Perceived Stress \\
Scale 14-item \\
inventory; \\
Mental \\
Component \\
Summary (MCS) \\
of the Short \\
Form-36 QoL \\
scale
\end{tabular} & $\begin{array}{l}\text { Secondary } \\
\text { outcome. }\end{array}$ & $\begin{array}{l}\text { Compared to usual care, HIIT did not lead to any } \\
\text { significant improvements in depression, anxiety, } \\
\text { stress, or sleep quality (depression: SMD- } 0.2 \\
\text { [95\%CI:-1.6;1.3], } \mathrm{p}=0.81 \text {; anxiety: SMD }-1.6 \\
\text { [95\%CI:-3.9; 0.8], p=0.19, stress: SMD }-1.7 \\
\text { [95\%CI:-4.4; 1.0], p=0.22, sleep: }-0.6 \text { [95\%CI:-1.4; } \\
\text { 0.2], p=0.15). Compared to UC, HIIT significantly } \\
\text { improved MCS (SMD: } 3.9 \text { [95\%CI: 0.3; 7.5], } \\
\text { p = 0.034). Compared to usual care, HIIT did not lead } \\
\text { to any significant improvements at 3-month follow-up } \\
\text { (depression: SMD-1.2 [95\%CI:-2.9; 0.5), p=0.17; } \\
\text { anxiety: SMD: }-1.3 \text { [95\%CI:-3.5; 0.9], p=0.25; stress - } \\
\text { 2.4 [95\%CI:-5.4; 0.7], p=0.12; sleep: SMD-0.7 } \\
\text { [95\%CI: }-1.8 ; 0.4], p=0.19 ; \text { MCS: SMD: } 1.3 \text { [95\%CI:- } \\
\text { 2.5; 5.0], p=0.51). }\end{array}$ & $\begin{array}{l}\text { No exercise-related } \\
\text { serious adverse events } \\
\text { were reported or } \\
\text { observed. }\end{array}$ & $\begin{array}{l}100 \% \text { of participants randomised to } \\
\text { HIIT and } 93 \% \text { randomised to usual } \\
\text { care completed the intervention, } \\
83 \% \text { and } 82 \% \text { completed the } 3- \\
\text { month follow-up respectively. } \\
\text { Exercise attendance was } 99 \% \text {. }\end{array}$ & $\begin{array}{l}\text { Twelve weeks of HIIT } \\
\text { may led to significant } \\
\text { improvements in } \\
\text { mental wellbeing, but } \\
\text { not depression, anxiety, } \\
\text { stress or sleep quality } \\
\text { in testicular cancer } \\
\text { survivors. }\end{array}$ \\
\hline $\begin{array}{l}\text { Egegaard et } \\
\text { al., } 2019\end{array}$ & $\begin{array}{l}\text { Hospital Anxiety } \\
\text { and Depression } \\
\text { Scale (HADS) }\end{array}$ & $\begin{array}{l}\text { Secondary } \\
\text { outcome. }\end{array}$ & $\begin{array}{l}\text { Results from the HADS Scale showed no significant } \\
\text { within or between group differences from baseline to } \\
\text { post intervention (anxiety: MD } 0.33 \text { [95\%CI:-2.99; } \\
3.64], p=0.829 \text {; depression: MD } 0.64 \text { [95\%CI:-2.62; } \\
\text { 3.91], } p=0.667 \text { ). }\end{array}$ & \begin{tabular}{|l} 
Two patients \\
were hospitalized due to \\
chemotherapy adverse \\
events. No adverse \\
events or any
\end{tabular} & $\begin{array}{l}\text { There were no dropouts. The overall } \\
\text { attendance rate to exercise was } \\
90.0 \% \text { (range: } 53.8-100.0 \%) \text {. }\end{array}$ & $\begin{array}{l}\text { Seven weeks of HIIT } \\
\text { did not led to changes } \\
\text { in depression nor } \\
\text { anxiety in a pilot study }\end{array}$ \\
\hline
\end{tabular}




\begin{tabular}{|c|c|c|c|c|c|c|}
\hline & & & & $\begin{array}{l}\text { unexpected reactions } \\
\text { were observed during } \\
\text { exercise sessions. }\end{array}$ & & $\begin{array}{l}\text { with lung cancer } \\
\text { patients. }\end{array}$ \\
\hline $\begin{array}{l}\text { Eather et } \\
\text { al., } 2019\end{array}$ & \begin{tabular}{|l|} 
Perceived Stress \\
Scale (PSS); \\
Spielberger \\
State-Trait \\
Anxiety \\
Inventory \\
(STAI)
\end{tabular} & $\begin{array}{l}\text { Secondary } \\
\text { outcome. }\end{array}$ & $\begin{array}{l}\text { No significant within or between group differences } \\
\text { from baseline to post intervention were observed for } \\
\text { perceived stress nor anxiety (stress: MD -1.1 [95\% CI: } \\
-4.2 ;-2.0], p=0.476, d=0.20 \text {; anxiety: MD }-0.2 \\
\text { [95\%CI:-1.5;-1.1], } \mathrm{p}=0.709, \mathrm{~d}=0.02 \text { ). }\end{array}$ & $\begin{array}{l}\text { Adverse events not } \\
\text { reported. }\end{array}$ & $\begin{array}{l}\text { Retention was } 75.5 \% \text { and average } \\
\text { attendance for HIIT sessions was } \\
66.7 \% \text { ( } 54.5 \% \text { of participants } \\
\text { attended } 2+\text { sessions/week). }\end{array}$ & $\begin{array}{l}\text { Eight weeks of HIIT } \\
\text { did not led to } \\
\text { improvements in } \\
\text { anxiety or perceived } \\
\text { stress in university } \\
\text { students. }\end{array}$ \\
\hline \begin{tabular}{|l|} 
Abdelhalem \\
et al., \\
2018
\end{tabular} & \begin{tabular}{l|} 
RAND 36-Item \\
Health Survey \\
mental \\
(emotional) \\
component
\end{tabular} & $\begin{array}{l}\text { Secondary } \\
\text { outcome. }\end{array}$ & $\begin{array}{l}\text { The HIIT group showed better improvement in } \\
\text { emotional wellbeing than the MICT group (MICT } \\
\text { pre: } 273.00 \pm 31.97, \text { Post: } 377.00 \pm 31.30 \text {; HIT pre: } \\
283.00 \pm 20.80, \text { post: } 398.00 \pm 15.76, t=-2.680 \\
\text { p }=0.011 \text { ). }\end{array}$ & $\begin{array}{l}\text { No serious adverse } \\
\text { events occurred during } \\
\text { the study. }\end{array}$ & $\begin{array}{l}\text { All the patients were compliant to } \\
\text { the program with no missing } \\
\text { sessions or dropouts. }\end{array}$ & $\begin{array}{l}\text { Both HIIT and MICT } \\
\text { lead to improvements } \\
\text { in emotional wellbeing } \\
\text { in patients with CAD, } \\
\text { although greater } \\
\text { improvements are seen } \\
\text { after HIIT. }\end{array}$ \\
\hline $\begin{array}{l}\text { Mason et } \\
\text { al., } 2018\end{array}$ & \begin{tabular}{|l|} 
Anxiety \\
Sensitivity \\
Index-3 (ASI-3); \\
Distress \\
Tolerance Scale \\
(DTS)
\end{tabular} & $\begin{array}{l}\text { Primary } \\
\text { outcome. }\end{array}$ & $\begin{array}{l}\text { Compared to control, both exercise groups reported } \\
\text { significant reductions in total ASI-3 scores. Medium } \\
\text { effects were found for changes in both SIT, } \mathrm{d}=-0.35 \\
(95 \% \text { CI }[-0.70,-0.07]) \text {, and MICT, } \mathrm{d}=-0.45(95 \% \\
\text { CI }[-0.80,-0.16]) \text {, although changes in anxiety were } \\
\text { not significantly different between SIT and MICT } \\
\text { groups }(\mathrm{d}=-0.10(95 \% \text { CI }[-0.44,0.25]) \text {. Neither SIT } \\
\text { nor MICT had significant effects on anxiety at } 3 \text { and } 7 \\
\text { day follow-up compared to control. Neither exercise } \\
\text { or control had a significant effect on distress scores. } \\
\text { SIT was associated with a non-significant reduction in } \\
\text { DTS scores }(\mathrm{d}=-0.15 \text { ( } 95 \% \text { CI }[-0.44,0.11]) \text {, while } \\
\text { MICT was associated with a non-significant reduction } \\
\text { in DTS scores and a trivial effect, } \mathrm{d}=-0.04(95 \% \mathrm{CI} \\
[-0.31,0.22]) \text {. }\end{array}$ & $\begin{array}{l}\text { Adverse events not } \\
\text { reported. } \\
\end{array}$ & $\begin{array}{l}82 \% \text { of participants completed the } \\
\text { first follow-up and } 80 \% \text { completed } \\
\text { the second follow-up. }\end{array}$ & $\begin{array}{l}\text { An acute bout of SIT } \\
\text { and MICT may led to } \\
\text { immediate reductions } \\
\text { in anxiety compared to } \\
\text { a non-active control. }\end{array}$ \\
\hline $\begin{array}{l}\text { Saanijoki et } \\
\text { al., } 2017\end{array}$ & $\begin{array}{l}\text { Perceived Stress } \\
\text { Questionnaire } \\
\text { (PSQ); Positive } \\
\text { and Negative } \\
\text { Affect Schedule } \\
\text { (PANAS) }\end{array}$ & $\begin{array}{l}\text { Primary } \\
\text { outcome. }\end{array}$ & $\begin{array}{l}\text { There was no group } \mathrm{X} \text { time interaction for neither } \\
\text { stress, positive nor negative affect (Stress: } \mathrm{F}=1.03 \text {, } \\
\mathrm{p}=0.32 \text {, positive affect: } \mathrm{F}=2.64, \mathrm{p}=0.12 \text {, negative } \\
\text { affect: } \mathrm{F}=0.09, \mathrm{p}=0.77 \text { ). }\end{array}$ & $\begin{array}{l}\text { One participant } \\
\text { experienced a migraine } \\
\text { during the first SIT } \\
\text { session, it is not clear if } \\
\text { this was an exercise- } \\
\text { related adverse event. }\end{array}$ & $\begin{array}{l}\text { Two subjects from the SIT group } \\
\text { dropped out during the trial, one } \\
\text { because of claustrophobic feelings } \\
\text { during baseline testing and one due } \\
\text { to migraine during the first SIT } \\
\text { session. Three subjects from the } \\
\text { MICT group discontinued the trial } \\
\text { due to personal reasons. } 11 \text { subjects } \\
\text { in SIT and } 10 \text { subjects in MICT } \\
\text { group finalized all their assigned } \\
\text { training sessions. }\end{array}$ & $\begin{array}{l}\text { Two weeks of HIIT did } \\
\text { not led to } \\
\text { improvements in stress } \\
\text { nor affect in insulin } \\
\text { resistant adults. }\end{array}$ \\
\hline
\end{tabular}




\begin{tabular}{|c|c|c|c|c|c|c|}
\hline $\begin{array}{l}\text { Connolly et } \\
\text { al., } 2017\end{array}$ & $\begin{array}{l}14 \text {-item } \\
\text { Warwick- } \\
\text { Edinburgh } \\
\text { Mental Well- } \\
\text { being Scale } \\
\text { (WEMWBS) }\end{array}$ & $\begin{array}{l}\text { Secondary } \\
\text { outcome. }\end{array}$ & $\begin{array}{l}\text { WEMWBS scores increased following CT (pre: } 49 \pm 9 \\
\text {, post: } 52 \pm 7, P<0.05 \text { ) but not HIIT (pre: } 52 \pm 9 \text {, post: } \\
54 \pm 7 \text { ) or CON (pre: } 42 \pm 8 \text {, post: } 42 \pm 6 \text { ). There was no } \\
\text { difference in WEMWBS between training groups } \\
(p=0.198 \text {, Partial } \eta 2=0.074) \text {. }\end{array}$ & $\begin{array}{l}\text { No study related } \\
\text { injuries were reported. }\end{array}$ & $\begin{array}{l}\text { One participant from HIIT and CT } \\
\text { withdrew from the study due to non- } \\
\text { study related injuries and one } \\
\text { participant from CON withdrew due } \\
\text { a substantial increase in physical } \\
\text { activity. Both HIIT and CT groups } \\
\text { completed a total of } 35 \pm 1 \\
\text { training sessions ( } 2.9 \pm 0.1 \text { sessions } \\
\text { per week). }\end{array}$ & $\begin{array}{l}12 \text { weeks of HIIT did } \\
\text { not lead to } \\
\text { improvements in } \\
\text { mental wellbeing in } \\
\text { inactive women. }\end{array}$ \\
\hline $\begin{array}{l}\text { Sosner et } \\
\text { al., } 2019\end{array}$ & $\begin{array}{l}\text { "Profile Of Moo } \\
\text { d States" } \\
\text { (POMS) test }\end{array}$ & $\begin{array}{l}\text { Secondary } \\
\text { outcome. }\end{array}$ & $\begin{array}{l}\text { Whereas MICT did not change any dimension of } \\
\text { mood, HITTryland moderately improved fatigue } \\
(-4.25 \pm 6.36, \mathrm{~g}=-0.32 ; \mathrm{P}=0.04) \text { and the energy } \\
\text { index }(+6.42 \pm 8.11, \mathrm{~g}=0.31 ; \mathrm{P}=0.02) \\
\text { while HIITimmersed resulted in a moderate decrease } \\
\text { in anxiety }(-3.18 \pm 4.27, \mathrm{~g}=-0.56 ; \mathrm{P}=0.04) \text { and } \\
\text { confusion }(-2.66 \pm 2.17, \mathrm{~g}=-0.58 ; \mathrm{P}=0.004) \text {. }\end{array}$ & $\begin{array}{l}\text { Adverse events not } \\
\text { reported. }\end{array}$ & $\begin{array}{l}\text { Eleven, twelve and ten participants } \\
\text { completed } \\
\text { MICT, HIITdryland or HIITimmers } \\
\text { ed conditions respectively. }\end{array}$ & $\begin{array}{l}\text { Two weeks of HIIT } \\
\text { may lead to } \\
\text { improvements in mood } \\
\text { states in hypertensive } \\
\text { adults. }\end{array}$ \\
\hline $\begin{array}{l}\text { Costigan et } \\
\text { al., } 2016\end{array}$ & $\begin{array}{l}\text { Psychological } \\
\text { well-being: 8- } \\
\text { item Flourishing } \\
\text { Scale; Kessler } \\
\text { Psychological } \\
\text { Distress Scale } \\
\text { (K10) }\end{array}$ & $\begin{array}{l}\text { Primary } \\
\text { outcome. }\end{array}$ & $\begin{array}{l}\text { Small intervention effects for well-being were found } \\
\text { for both HIIT conditions (HIIT: } 2.81,95 \% \mathrm{CI}=-2.06 \\
\text { to } 7.68 ; \mathrm{d}=0.34,95 \% \mathrm{CI}=-3.84 \text { to } 3.32 ; \mathrm{HIIT}-\mathrm{RT} \text { : } \\
2.96,95 \% \mathrm{CI}=-1.82 \text { to } 7.75 ; \mathrm{d}=0.36,95 \% \mathrm{CI}= \\
-3.86 \text { to } 3.13 \text { ), although these changes were not } \\
\text { significantly different from the control group (SMD: } \\
\text { 2.96 [95\%CI: }-1.82 ; 7.75], \mathrm{p}=0.219 \text { ). There were no } \\
\text { intervention effects for psychological distress for } \\
\text { either HIIT groups, compared to control (SMD:-0.19 } \\
\text { [95\%CI: }-2.97 ; 2.59\}, \mathrm{p}=0.891] \text {. }\end{array}$ & $\begin{array}{l}\text { Adverse events not } \\
\text { reported. }\end{array}$ & Attendance not reported. & $\begin{array}{l}\text { While results were not } \\
\text { significant, HIT may } \\
\text { improve mental health } \\
\text { markers in adolescents. }\end{array}$ \\
\hline $\begin{array}{l}\text { Dunne et } \\
\text { al., } 2016\end{array}$ & $\begin{array}{l}\text { Mental } \\
\text { Component } \\
\text { Summary (MCS) } \\
\text { of the Short } \\
\text { Form-36 QoL } \\
\text { scale }\end{array}$ & $\begin{array}{l}\text { Secondary } \\
\text { outcome. }\end{array}$ & $\begin{array}{l}\text { Compared to standard care, HIIT was associated with } \\
\text { improvements in overall SF-36 mental health (HIIT: } \\
\text { pre: 66(22), post: } 77(19) \text {, change: }+11 \text { [95\%CI: 5, 18), } \\
\text { Con: pre:72(19), post:72(23), change: } 0 \text { [95\%CI:-9, } \\
\text { 9], P =0.037) scores. }\end{array}$ & $\begin{array}{l}\text { There were no reported } \\
\text { adverse outcomes of the } \\
\text { exercise intervention. }\end{array}$ & $\begin{array}{l}\text { Nineteen patients completed HIIT } \\
\text { and } 15 \text { patients completed standard } \\
\text { care follow-up. One HIIT patient } \\
\text { was lost after developing an } \\
\text { unrelated malignancy. Of HIIT } \\
\text { patients, } 18 \text { of } 19 \text { completed } 100 \% \\
\text { of the exercise sessions, with one } \\
\text { patient missing two sessions due to } \\
\text { primary tumour care. }\end{array}$ & $\begin{array}{l}\text { Four weeks of HIIT } \\
\text { may lead to } \\
\text { improvements } \\
\text { in menatl wellbeing in } \\
\text { patients undergoing } \\
\text { CRLM. }\end{array}$ \\
\hline \begin{tabular}{|l|} 
Rizk et al., \\
2015
\end{tabular} & $\begin{array}{l}\text { Positive and } \\
\text { Negative Affect } \\
\text { Schedule } \\
\text { (PANAS); } \\
\text { global vigour an } \\
\text { d affect (GVA) } \\
\text { instrument } \\
\text { (global affect) }\end{array}$ & $\begin{array}{l}\text { Primary } \\
\text { outcome. }\end{array}$ & $\begin{array}{l}\text { PANAS results revealed a significant time effect from } \\
\text { rest to post-exercise for positive }(\mathrm{F}=9.74, \mathrm{p}<0.001) \\
\text { and negative }(\mathrm{F}=6.43, \mathrm{p}=0.005) \text { affect scores, but } \\
\text { no time by intervention group interaction. GVA } \\
\text { results indicated a significant time effect from rest to } \\
\text { post-exercise for both global affect }(\mathrm{F}=8.47, \mathrm{p}< \\
0.001) \text { and vigour }(\mathrm{F}=9.79, \mathrm{p}<0.001) \text { but time by } \\
\text { intervention group interaction observed a significant } \\
\text { increase in vigour following CTHI and CTVT, but not } \\
\text { following HIIT }(\mathrm{p}<0.05) \text {. }\end{array}$ & $\begin{array}{l}\text { Adverse events not } \\
\text { reported. }\end{array}$ & $\begin{array}{l}\text { Mean attendance was not } \\
\text { significantly different between } \\
\text { groups (CTHI: 70.1 } \pm 32.9 \% \text { (range: } \\
\text { 49.3-91.0); CTVT: } 81.9 \pm 17.2 \% \\
\text { (range: 71.0-92.9); IT: } 73.3 \pm 28.6 \% \\
\text { (range: } 52.9-93.8), \mathrm{F}=0.61, \mathrm{p}= \\
0.55 \text { ). }\end{array}$ & $\begin{array}{l}\text { An acute bout of HIIT } \\
\text { may lead to } \\
\text { improvements in } \\
\text { positive and negative } \\
\text { COffect in patients with } \\
\text { improvements are } \\
\text { imot disimilar to those } \\
\text { seen following an acute }\end{array}$ \\
\hline
\end{tabular}




\begin{tabular}{|c|c|c|c|c|c|c|}
\hline & & & & & & $\begin{array}{l}\text { bout of CTHI or } \\
\text { CTVT. }\end{array}$ \\
\hline $\begin{array}{l}\text { Pedersen et } \\
\text { al., } 2015\end{array}$ & $\begin{array}{l}\text { Hospital Anxiety } \\
\text { and Depression } \\
\text { Scale (HADS) }\end{array}$ & $\begin{array}{l}\text { Secondary } \\
\text { outcome. }\end{array}$ & $\begin{array}{l}\text { A decrease was obtained in the HADS-A score in both } \\
\text { groups with no between group differences (HIIT } \\
\text { change: }-1.0 \text { [95\%CI:-1.9; -0.04]; LED change: -0.6 [- } \\
1.2 ;-0.05] \text { ) while HADS-D remained unchanged } \\
\text { (HIIT change: -0.4 [95\%CI: }-1.1 ; 0.3 \text { ]; LED change: - } \\
0.2 \text { [95\%CI: }-1.1 ; 0.7]) \text {. }\end{array}$ & \begin{tabular}{|l|} 
No serious adverse \\
events were seen related \\
to either intervention. \\
Side effects to LED \\
were mild (dizziness \\
$(\mathrm{n}=10)$, headaches \\
$(\mathrm{n}=9)$, obstipation \\
$(\mathrm{n}=9)$ and fatigue \\
$(\mathrm{n}=7))$.
\end{tabular} & $\begin{array}{l}\text { Twenty-six (74\%) HIIT and } 29 \\
\text { (83\%) LED participants completed } \\
\text { intervention per protocol. }\end{array}$ & $\begin{array}{l}12 \text { weeks of HIIT may } \\
\text { be associated with a } \\
\text { reduction in anxiety } \\
\text { and no change in } \\
\text { depressive symptoms in } \\
\text { patients with CAD, } \\
\text { although improvements } \\
\text { seen are similar when } \\
\text { compared to LED. } \\
\end{array}$ \\
\hline \begin{tabular}{|l|} 
Saanijoki et \\
al., 2015
\end{tabular} & $\begin{array}{l}\text { Perceived Stress } \\
\text { Questionnaire } \\
\text { (PSQ), The } \\
\text { Positive and } \\
\text { Negative Affect } \\
\text { Schedule } \\
\text { (PANAS) } \\
\end{array}$ & $\begin{array}{l}\text { Primary } \\
\text { outcome. }\end{array}$ & $\begin{array}{l}\text { HIIT versus MIT exercise acutely increased perceived } \\
\text { stress (group } \mathrm{X} \text { time interaction } \mathrm{F}=8.69, \mathrm{p}=0.007) \text { and } \\
\text { decreased positive affect }(\mathrm{F}=4.33, \mathrm{p}=0.049) \text {. } \\
\text { Participants in the HIT group experienced more } \\
\text { negative affect than the MICT group }(\mathrm{F}=5.84, \\
\mathrm{p}=0.024) \text {. }\end{array}$ & $\begin{array}{l}\text { Adverse events not } \\
\text { reported. }\end{array}$ & \begin{tabular}{|l|} 
During the intervention, one subject \\
from both groups dropped out; thus, \\
26 subjects completed the study. All \\
six exercise sessions were \\
performed by all participants except \\
one MIT participant who performed \\
only four exercise sessions.
\end{tabular} & \begin{tabular}{|l|} 
HIT increases \\
experience of negative \\
emotions in sedentary \\
adults.
\end{tabular} \\
\hline \begin{tabular}{|l|} 
Chrysohoou \\
et al., \\
2014
\end{tabular} & $\begin{array}{l}\text { Zung Depression } \\
\text { Rating Scale } \\
\text { (ZDRS) }\end{array}$ & $\begin{array}{l}\text { Secondary } \\
\text { outcome. }\end{array}$ & $\begin{array}{l}\text { No between group differences were observed } \\
\text { regarding depression status of patients; however, } \\
\text { ZDRS scores was significantly lower after } \\
\text { intervention in the exercise group }(\mathrm{P}=0.005) \text {, while } \\
\text { they remained similar in the control group }(\mathrm{P}=0.19) \\
\text { (HIIT: pre }=37 \pm 8, \text { post }=30 \pm 6 \text {; Con: pre }=37 \pm 8, \\
\text { post }=41 \pm 10, \mathrm{p}=0.54) .\end{array}$ & \begin{tabular}{|l|} 
No serious adverse \\
events related to \\
exercise were observed.
\end{tabular} & $\begin{array}{l}\text { Thirty-three participants from the } \\
\text { HIIT group completed the } \\
\text { intervention and were analysed, } 39 \\
\text { participants remained in the non- } \\
\text { active control for analysis. }\end{array}$ & \begin{tabular}{|l|} 
Twelve weeks of HIIT \\
may possibly improve \\
depressive symptoms in \\
patients with CHF, \\
although more research \\
is needed.
\end{tabular} \\
\hline \begin{tabular}{|l} 
Fu et al., \\
2013
\end{tabular} & \begin{tabular}{|l|} 
Mental \\
Component \\
Summary (MCS) \\
of the Short \\
Form-36 QoL \\
scale
\end{tabular} & $\begin{array}{l}\text { Secondary } \\
\text { outcome. }\end{array}$ & $\begin{array}{l}\text { HIIT significantly increased the subclass scores of the } \\
\text { mental ( } 43.3 \text { to } 51.3 \text { ) dimension in SF-36. However, } \\
\text { MICT and non-active control scores remained } \\
\text { unchanged for SF-36 mental components. }\end{array}$ & $\begin{array}{l}\text { Adverse events not } \\
\text { reported. }\end{array}$ & $\begin{array}{l}\text { The rates of compliance with the } \\
\text { HIIT, MICT, and control subjects } \\
\text { were } 93.3 \%, 86.7 \% \text {, and } 86.7 \% \text {, } \\
\text { respectively. }\end{array}$ & \begin{tabular}{|l|} 
Twelve weeks of HIIT \\
may improve mental \\
wellbeing more that \\
MICT and non-active \\
controls in patients \\
with HF.
\end{tabular} \\
\hline
\end{tabular}




\begin{tabular}{|c|c|c|c|c|c|c|}
\hline $\begin{array}{l}\text { Terada et } \\
\text { al., } 2013\end{array}$ & \begin{tabular}{|l} 
Subjective \\
exercise \\
experiences \\
scale (SEES), a \\
12-item, 7-point \\
Likert scale to \\
assess positive \\
and negative \\
feeling states: \\
positive well- \\
being, \\
psychological \\
distress, and \\
fatigue \\
\end{tabular} & \begin{tabular}{|l|} 
Secondary \\
outcome.
\end{tabular} & $\begin{array}{l}\text { Changes in positive well being, psychological distress } \\
\text { and fatigue were not significant. There were no } \\
\text { differences between HIIT and MICT (HIIT: } \\
\text { psychological wellbeing pre: } 5.5 \pm 1.0 \text {, post: } 5.6 \pm 1.0 \text {; } \\
\text { psychological distress pre: } 1.9 \pm 0.9 \text {, post: } 1.2 \pm 0.2 \\
\text { fatigue pre: } 2.5 \pm 0.9 \text {, post: } 2.6 \pm 1.6 \text {; MICT: } \\
\text { psychological wellbeing pre: } 5.4 \pm 1.2 \text {, post: } 6.5 \pm 0.5 \text {; } \\
\text { psychological distress pre: } 2.1 \pm 1.3 \text {, post: } 1.1 \pm 0.2 \\
\text { fatigue pre: } 3.2 \pm 1.7 \text {, post: } 1.9 \pm 1.0)\end{array}$ & $\begin{array}{l}\text { Adverse events not } \\
\text { reported. }\end{array}$ & $\begin{array}{l}\text { No participants were lost to follow- } \\
\text { up. Both HIIT and MICT groups had } \\
\text { similar exercise adherence ( } 97.2 \pm \\
2.7 \text { and } 97.3 \pm 3.7 \% \text { of the eligible } \\
\text { exercise sessions completed within } \\
\text { HIIT and MICT conditions, } \\
\text { respectively). Reasons for not } \\
\text { attending sessions included: health } \\
\text { issues, automobile troubles, and } \\
\text { work. }\end{array}$ & $\begin{array}{l}\text { HIIT did not } \\
\text { significantly change } \\
\text { well-being, although } \\
\text { research with a larger } \\
\text { sample size is } \\
\text { warranted. }\end{array}$ \\
\hline $\begin{array}{l}\text { Freyssin et } \\
\text { al., } 2012\end{array}$ & $\begin{array}{l}\text { Hospital Anxiety } \\
\text { and Depression } \\
\text { Scale (HADS) }\end{array}$ & $\begin{array}{l}\text { Secondary } \\
\text { outcome. }\end{array}$ & $\begin{array}{l}\text { The level of anxiety and depression was significantly } \\
\text { improved by both HIIT and CT. This improvement } \\
\text { was not significantly different between groups } \\
\text { (HADS-D: HIIT= pre: } 6.6 \pm 1.8 \text {, post: } 3.4 \pm 2.5, \mathrm{CT}= \\
\text { pre: } 7.3 \pm 2.3 \text {, post: } 3.1 \pm 1.3 \text {, interaction effect } \mathrm{p}=0.501 \text {; } \\
\text { HADS-A: HIIT }=\text { pre: } 8.8 \pm 3.5 \text {, post: } 6.5 \pm 3.1, \mathrm{CT}=\text { pre: } \\
9.4 \pm 4.8 \text {, post: } 6.7 \pm 3.8 \text {, interaction effect } \mathrm{p}=0.792 \text { ). }\end{array}$ & $\begin{array}{l}\text { No cardiac event and no } \\
\text { major decompensation } \\
\text { were observed. }\end{array}$ & $\begin{array}{l}\text { The adherence to the training was } \\
100 \% \text { with no dropouts. }\end{array}$ & $\begin{array}{l}\text { Both HIIT and CT may } \\
\text { improve symptoms of } \\
\text { anxiety and depression } \\
\text { in patients with HF } \\
\text { with no between group } \\
\text { differences. }\end{array}$ \\
\hline $\begin{array}{l}\text { Christensen } \\
\text { et al., } 2012\end{array}$ & $\begin{array}{l}\text { Hospital Anxiety } \\
\text { and Depression } \\
\text { Scale (HADS); } \\
\text { Mental } \\
\text { Component } \\
\text { Summary (MCS) } \\
\text { of the Short } \\
\text { Form-36 QoL } \\
\text { scale }\end{array}$ & $\begin{array}{l}\text { Primary } \\
\text { outcome of } \\
\text { this sub- } \\
\text { study which } \\
\text { is a } \\
\text { secondary } \\
\text { analysis of } \\
\text { the main } \\
\text { RCT. }\end{array}$ & $\begin{array}{l}\text { A significant reduction in anxiety and depression was } \\
\text { seen in the HIIT group but not the control group } \\
\text { (HADS-A: HIIT pre: } 4.7 \pm 1.8 \text {, post: } 1.8 \pm 1.2 \text {, Control } \\
\text { pre: } 3.2 \pm 1.6 \text {, post: } 3.7 \pm 2.3 \text {, p=0.001; HADS-D: HIIT } \\
\text { pre: } 1.9 \pm 1.8 \text {, post: } 0.7 \pm 0.8 \text {, Control pre: } 1.8 \pm 1.1 \text {, post: } \\
1.3 \pm 0.9, p=0.034) \text {. A significant effect on mental } \\
\text { health was found (HIIT pre: } 81.7 \pm 15.1 \text {, post: } \\
90.0 \pm 8.1 \text {, Control pre: } 86.3 \pm 7.9 \text {, post: } 81.9 \pm 8.9 \text {, } \\
\text { p=0.03). }\end{array}$ & $\begin{array}{l}\text { No serious adverse } \\
\text { events were observed. } \\
\text { In one subject in the } \\
\text { HIIT group, } \\
\text { antihypertensive } \\
\text { medication had to be } \\
\text { reduced due to } \\
\text { symptomatic } \\
\text { hypotension. }\end{array}$ & $\begin{array}{l}\text { All patients completed the } \\
\text { intervention. }\end{array}$ & $\begin{array}{l}\text { Eight weeks of HIIT } \\
\text { may lead to greater } \\
\text { improvements in } \\
\text { anxiety and depressive } \\
\text { symptoms in heart } \\
\text { transplant recipients } \\
\text { when compared to } \\
\text { usual care. }\end{array}$ \\
\hline $\begin{array}{l}\text { Arnardottir } \\
\text { et al., } 2007\end{array}$ & $\begin{array}{l}\text { Hospital Anxiety } \\
\text { and Depression } \\
\text { Scale (HADS); } \\
\text { Mental } \\
\text { Component } \\
\text { Summary (MCS) } \\
\text { of the Short } \\
\text { Form-36 QoL } \\
\text { scale }\end{array}$ & $\begin{array}{l}\text { Secondary } \\
\text { outcome. }\end{array}$ & $\begin{array}{l}\text { Anxiety, depression and the mental health SF-36 } \\
\text { subdomain were significantly improved by training in } \\
\text { both groups (HADS-A: HIIT pre }=7.2 \pm 4.5 \text {, post }=5.2 \\
\pm 4.3 \text {; MICT pre }=6.9 \pm 3.5 \text {, post }=4.8 \pm 3.9 \text {; HADS-D: } \\
\text { HIIT pre }=5.8 \pm 3.6 \text { ), post }=4.3 \pm 3.6 \text {; MICT pre }=5.4 \\
\pm 3.2 \text {, post }=4.0 \pm 3.0 \text {; Mental health: HIIT pre }=65.1 \\
\pm 25.0 \text {, post }=75.8 \pm 17.3 \text {; MICT pre: } 69.1 \pm 9.5 \text {, post: } \\
75.7 \pm 16.9 \text { ). There was, however, no significant } \\
\text { between-groups difference. }\end{array}$ & $\begin{array}{l}\text { Twenty-four patients } \\
\text { dropped out due to } \\
\text { exacerbations, it is not } \\
\text { clear if these were } \\
\text { exercise-related. }\end{array}$ & $\begin{array}{l}\text { One hundred patients were included, } \\
\text { and } 60 \text { patients completed } \\
\text { the programme. The reason for } \\
\text { drop-out were exacerbations }(\mathrm{n}=24) \text {, } \\
\text { lack of motivation or transport } \\
\text { problems ( } \mathrm{n}=10) \text {, other diseases } \\
(\mathrm{n}=5) \text { and family problems }(\mathrm{n}=1) \text {. } \\
\text { The patients who completed } \\
\text { the programme had a mean } \\
\text { attendance rate of } 29 \pm 3 \text { of } 32 \\
\text { possible sessions (no difference in } \\
\text { attendance rate between the two } \\
\text { training groups). }\end{array}$ & $\begin{array}{l}\text { Sixteen weeks of both } \\
\text { HIIT and MICT may } \\
\text { improve mental health } \\
\text { markers in patients } \\
\text { with COPD. }\end{array}$ \\
\hline
\end{tabular}




\begin{tabular}{|c|c|c|c|c|c|c|}
\hline $\begin{array}{l}\text { Tew et al., } \\
2019\end{array}$ & $\begin{array}{l}\text { Hospital Anxiety } \\
\text { and Depression } \\
\text { Scale (HADS); } \\
\text { EQ 5D-5L } \\
\text { anxiety/depressi } \\
\text { on subscale }\end{array}$ & $\begin{array}{l}\text { Secondary } \\
\text { outcome. }\end{array}$ & $\begin{array}{l}\text { No between group differences were observed } \\
\text { regarding depression and anxiety (HADS-A: HIIT } \\
\text { pre: } 5.5 \pm 3.9,3 \text { month: } 5.2 \pm 2.5,6 \text { month: } 3.8 \pm 3.5 \text {; } \\
\text { MICT pre: } 6.8 \pm 5.2,3 \text { month: } 5.5 \pm 3.6,6 \text { month: } 5.3 \\
\pm 4.3 \text {; Con pre: } 7.7 \pm 4.3,3 \text { month: } 6.2 \pm 4.2,6 \text { month: } \\
5.5 \pm 3.6 \text {; HADS-D: HIT pre: } 3.6 \pm 3.1,3 \text { month: } 2.7 \\
\pm 1.7,6 \text { month: } 2.7 \pm 1.5 ; \text { MICT pre:3.8 } \pm 2.9,3 \text { month: } \\
2.7 \pm 3.3,6 \text { month: } 3.1 \pm 3.1 \text {; Con pre: } 5.2 \pm 2.9,3 \\
\text { month: } 2.6 \pm 2.5,6 \text { month: } 4.4 \pm 4.0 \text { ). No between } \\
\text { group differences were observed on the ED 5D-5L } \\
\text { anxiety/depression subscale (HIIT pre: } 1.54 \pm 0.78, \\
3 \text { month: } 1.42 \pm 0.52,6 \text { month: } 1.30 \pm 0.48, \text { MICT pre: } \\
1.83 \pm 0.72,3 \text { month: } 1.58 \pm 0.79,6 \text { month: } 1.64 \pm 0.51 \text {, } \\
\text { Con pre: } 1.82 \pm 1.25,3 \text { month: } 1.73 \pm 0.79,6 \text { month: } \\
\text { 2.0 } 0.89 \text { ). }\end{array}$ & $\begin{array}{l}\text { There were three non- } \\
\text { serious exercise-related } \\
\text { adverse events, all } \\
\text { related to HIIT. These } \\
\text { included vomiting, } \\
\text { dehydration and } \\
\text { dizziness. }\end{array}$ & $\begin{array}{l}\text { No participants formally withdrew, } \\
\text { but one HIIT participant was lost to } \\
\text { the 6-month follow-up. } 62 \% \text { and } \\
75 \% \text { of sessions were attended in } \\
\text { HIIT and MICT groups } \\
\text { respectively. }\end{array}$ & $\begin{array}{l}\text { Twelve weeks of HIIT } \\
\text { did not lead to superior } \\
\text { improvements in } \\
\text { anxiety and depression } \\
\text { when compared to } \\
\text { MICT and usual care in } \\
\text { patients with Crohn's } \\
\text { disease. }\end{array}$ \\
\hline $\begin{array}{l}\text { Choi et al., } \\
2018\end{array}$ & $\begin{array}{l}\text { Hospital Anxiety } \\
\text { and Depression } \\
\text { Scale } \\
\text { (HADS); PHQ- } \\
\text { 9 (Patient Health } \\
\text { Questionnaire-9) } \\
\text { (depression); } \\
\text { Insomnia } \\
\text { Severity Index } \\
\text { (ISI) }\end{array}$ & $\begin{array}{l}\text { Primary } \\
\text { outcome. }\end{array}$ & 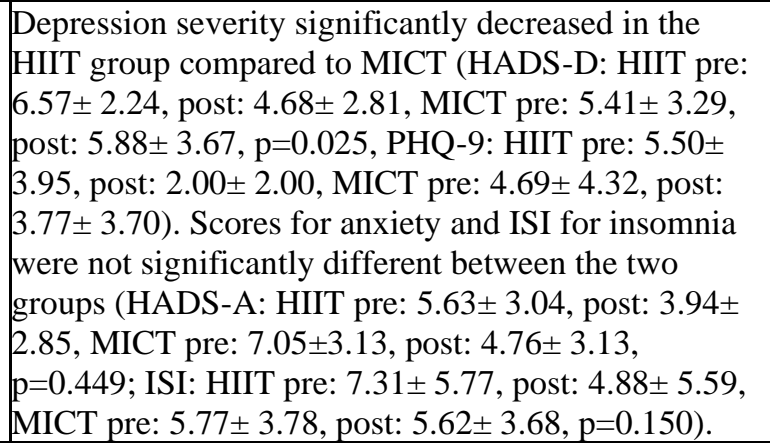 & $\begin{array}{l}\text { Two patients (one } \\
\text { patient in each group) } \\
\text { could not finish all } 18 \\
\text { sessions because of } \\
\text { ankle injury and } \\
\text { occupational reasons. } \\
\text { The remaining } 44 \\
\text { patients completed } 18 \\
\text { sessions of exercise } \\
\text { without any adverse } \\
\text { events. }\end{array}$ & $\begin{array}{l}23 \text { patients in the HIIT group and } 21 \\
\text { patients in the control group were } \\
\text { analyzed in this study, they } \\
\text { completed all } 18 \text { sessions. }\end{array}$ & $\begin{array}{l}18 \text { sessions of HIIT } \\
\text { may reduce depressive } \\
\text { symptoms in patients } \\
\text { with PI compared to } \\
\text { MICT, although no } \\
\text { effects on insomnia or } \\
\text { anxiety were found. }\end{array}$ \\
\hline $\begin{array}{l}\text { Shepherd et } \\
\text { al., } 2015\end{array}$ & \begin{tabular}{|l|} 
Positive and \\
Negative Affect \\
Schedule \\
(PANAS); 12 \\
item Exercise- \\
Induced Feeling \\
Inventory (acute \\
moods)
\end{tabular} & $\begin{array}{l}\text { Secondary } \\
\text { outcome. }\end{array}$ & $\begin{array}{l}\text { There was a significant increase in positive affect as a } \\
\text { result of the training }\left(\mathrm{p}<0.01 ; \eta \mathrm{p}^{2}=.14\right) \text { and a } \\
\text { significant decrease in negative affect in both groups } \\
\left(\mathrm{p}=0.05 ; \eta \mathrm{p}^{2}=.04\right) \text {, there were no between-group } \\
\text { differences and these gains were not sustained at } 3 \text { - } \\
\text { month follow-up. The effects of single exercise } \\
\text { sessions on acute moods were assessed immediately } \\
\text { after the training sessions in weeks } 4 \text { and } 8 \text { in both } \\
\text { groups. There were no significant differences between } \\
\left.\text { the groups in either week } 4 \text { ( }>0.05 ; \eta \mathrm{p}^{2}=.08\right) \text { or } \\
\text { week } 8\left(\mathrm{p}>0.05 ; \eta \mathrm{p}^{2}=.08\right) .\end{array}$ & $\begin{array}{l}\text { Adverse events not } \\
\text { reported. }\end{array}$ & $\begin{array}{l}\text { Adherence to the training } \\
\text { intervention was significantly } \\
\text { greater in the HIT group }(83 \pm 14 \% \\
\text { prescribed sessions attended; } \mathrm{n}=42) \\
\text { compared to the MICT group } \\
(61 \pm 15 \% \text { of prescribed sessions } \\
\text { attended; } \mathrm{t} 67.74=4.51 ; \mathrm{p}<0.001 ; \mathrm{n} \\
=36) \text {. Overall, } 4 \text { and } 8 \text { people in the } \\
\text { HIIT and MICT groups, } \\
\text { respectively, were lost to follow-up } \\
\text { at } 10 \text { weeks. }\end{array}$ & $\begin{array}{l}\text { Ten weeks of HIIT and } \\
\text { MICT may improve } \\
\text { positive and negative } \\
\text { affect within no } \\
\text { differences between the } \\
\text { two training regimes. }\end{array}$ \\
\hline
\end{tabular}




\begin{tabular}{|c|c|c|c|c|c|c|}
\hline $\begin{array}{l}\text { Puhan et } \\
\text { al., } 2006\end{array}$ & $\begin{array}{l}\text { Hospital Anxiety } \\
\text { and Depression } \\
\text { Scale (HADS) }\end{array}$ & $\begin{array}{l}\text { Secondary } \\
\text { outcome. }\end{array}$ & $\begin{array}{l}\text { Improvements in depression and anxiety symptoms } \\
\text { were similar across groups (HADS-D: HIIT mean } \\
\text { difference from baseline (MD) } 2.05 \pm 2.90 \text {, HICT MD } \\
2.93 \pm 2.80 \text {, adjusted difference }-0.58 \text { [95\% CI:- } 1.65 \text {; } \\
\text { 0.49]; HASD-A: HIIT MD } 1.95 \pm 2.22 \text {, HICT MD } \\
2.25 \pm 3.09 \text {, adjusted difference }-0.22 \text { [-95\% CI:-1.24; } \\
0.80] \text { ). }\end{array}$ & $\begin{array}{l}\text { Eleven patients did not } \\
\text { complete the } \\
\text { rehabilitation because of } \\
\text { COPD exacerbations (3 } \\
\text { HIIT, 2 HICT); } \\
\text { musculoskeletal pain (2 } \\
\text { HIIT, 1 HICT); and, in } \\
\text { the HICT group only, } \\
\text { chest pain, an accident, } \\
\text { and lung cancer. It is } \\
\text { not clear if any of these } \\
\text { event were exercise } \\
\text { related. }\end{array}$ & $\begin{array}{l}\text { One patient in each group withdrew } \\
\text { informed consent for unspecified } \\
\text { reasons. Forty-three }(89.6 \%) \text { and } 44 \\
(88.0 \%) \text { patients completed the } \\
\text { inpatient rehabilitation in the HIIT } \\
\text { and HICT groups, respectively. }\end{array}$ & \begin{tabular}{|l|} 
Improvements in \\
anxiety and depression \\
are similar following \\
both HIIT and HICT \\
regimes of duration 3 \\
weeks in patients with \\
COPD.
\end{tabular} \\
\hline $\begin{array}{l}\text { Freese et } \\
\text { al., } 2014\end{array}$ & $\begin{array}{l}\text { 30-item Profile } \\
\text { of Mood States- } \\
\text { Brief } \\
\text { Questionnaire } \\
\text { (POMS-B); } \\
\text { Mental } \\
\text { Component } \\
\text { Summary (MCS) } \\
\text { of the Short } \\
\text { Form-36 QoL } \\
\text { scale }\end{array}$ & $\begin{array}{l}\text { Primary } \\
\text { outcome. }\end{array}$ & 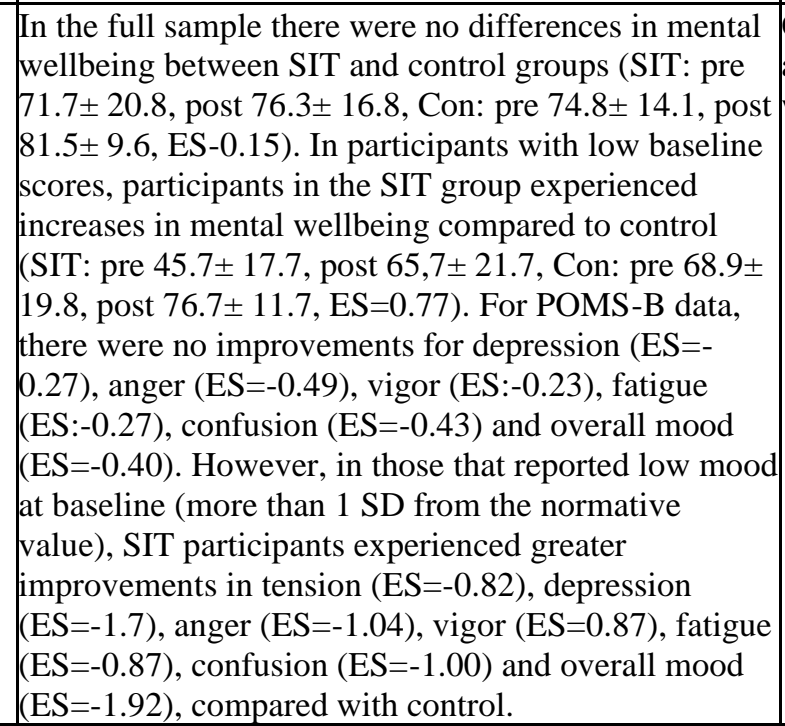 & $\begin{array}{l}\text { One patient experienced } \\
\text { an injury that } \\
\text { was non related to SIT. } \\
\end{array}$ & $\begin{array}{l}14 \text { withdrew or were excluded } \\
\text { (for non compliance) during the } \\
\text { intervention }(8=\text { control, } 6=\text { SIT }) \text {. } \\
\text { The remaining participants } \\
\text { completed all } 18 \text { sessions. }\end{array}$ & \begin{tabular}{|l|} 
Six weeks of SIT \\
may led to positive \\
improvements in \\
mental wellbeing and \\
mood, in women at risk \\
for MetS, compared to \\
non-active control, but \\
only in those with \\
below average scores at \\
baseline.
\end{tabular} \\
\hline \begin{tabular}{|l} 
Jurado- \\
Fasoli et al., \\
2020
\end{tabular} & $\begin{array}{l}\text { Pittsburgh Sleep } \\
\text { Quality Index } \\
\text { (PSQI); sleep } \\
\text { time }\end{array}$ & $\begin{array}{l}\text { Primary } \\
\text { outcome. }\end{array}$ & $\begin{array}{l}\text { All intervention groups showed a lower PSQI global } \\
\text { score at follow-up compared to baseline }(4.81 \pm 3.85 \\
\text { vs } 3.06 \pm 2.57, \mathrm{P}=.013 ; 5.47 \pm 3.74 \text { vs } 3.53 \pm 2.53, \mathrm{P} \\
=.003 ; 5.56 \pm 2.73 \text { vs } 3.44 \pm 2.58, \mathrm{P}=.022 ; \text { for PAR, } \\
\text { HIIT and HIIT-EMS, respectively), while no } \\
\text { differences were observed in the control group. There } \\
\text { were no pairwise differences among groups in PSQI } \\
\text { global score, total sleep time, sleep efficiency and } \\
\text { wake after sleep onset (all } \mathrm{P}>.05 \text { ). }\end{array}$ & $\begin{array}{l}\text { No adverse events } \\
\text { occurred during the } \\
\text { exercise sessions. }\end{array}$ & $\begin{array}{l}\text { Eleven participants were lost at } \\
\text { follow-up (control group: 5; PAR: 3; } \\
\text { HIIT: 2; HIIT-EMS: 1). Participants } \\
\text { attended } 98.7 \% \text { of their exercise } \\
\text { sessions. }\end{array}$ & \begin{tabular}{|l|} 
Twelve weeks of PAR, \\
HIIT and HIIT-EMS \\
induced an \\
improvement in \\
subjective sleep quality \\
in sedentary middle \\
aged adults.
\end{tabular} \\
\hline $\begin{array}{l}\text { Bruseghini } \\
\text { et al., } 2020\end{array}$ & sleep time & $\begin{array}{l}\text { Secondary } \\
\text { outcome. }\end{array}$ & $\begin{array}{l}\text { Sleep time remained constant during the intervention } \\
\text { and no between group interaction was found. }\end{array}$ & $\begin{array}{l}\text { No injuries or health } \\
\text { disorders occurred. }\end{array}$ & $\begin{array}{l}\text { No dropouts were recorded during } \\
\text { the study period. }\end{array}$ & $\begin{array}{l}\text { Tweleve weeks of HIIT } \\
\text { had no effect on sleep } \\
\text { time in older adults. }\end{array}$ \\
\hline
\end{tabular}




\begin{tabular}{|c|c|c|c|c|c|c|}
\hline $\begin{array}{l}\text { Chou et al., } \\
2019\end{array}$ & \begin{tabular}{|l|} 
Mental \\
Component \\
Summary (MCS) \\
of the Short \\
Form-36 QoL \\
scale
\end{tabular} & Secondary & $\begin{array}{l}\text { HIIT significantly increased mental dimensions in SF- } \\
\text { 36, however mental health scores remained } \\
\text { unchanged in the control group (HIIT } 44.5 \pm 4.5 \text { to } \\
52.1 \pm 4.4 \text {, Con } 46.3 \pm 6.3 \text { to } 45.1 \pm 6.7, \mathrm{P}<0.05 \text { ). }\end{array}$ & $\begin{array}{l}\text { Adverse events not } \\
\text { reported. }\end{array}$ & $\begin{array}{l}\text { The compliance rates with HIIT and } \\
\text { GHC patients were } 88.2 \% \text { and } \\
88.2 \% \text {, respectively. }\end{array}$ & $\begin{array}{l}\text { Twelve weeks of HIIT } \\
\text { may improve mental } \\
\text { wellbeing in patients } \\
\text { with HF compared to } \\
\text { general healthcare. }\end{array}$ \\
\hline $\begin{array}{l}\text { Hurst et al., } \\
2019\end{array}$ & \begin{tabular}{|l|} 
Mental \\
Component \\
Summary (MCS) \\
of the Short \\
Form-36 QoL \\
scale
\end{tabular} & $\begin{array}{l}\text { Secondary } \\
\text { outcome. }\end{array}$ & $\begin{array}{l}\text { There were possibly small beneficial effects for the } \\
\text { SF-36 mental health domain in the HIT group } \\
\text { compared with control (HIIT adjusted mean change } \\
2.9 \text { [90\%CI: } 0.7 ; 5.0 \text { ), Con adjusted } \\
\text { mean change } 0.1 \text { [90\%CI:- } 2.3 ; 2.1] \text {, between-group } \\
\text { difference } 2.9 \text { [90\%CI:- } 0.1 ; 6.0] \text {. MCS score } \\
\text { increased in the HIIT group and decreased in the } \\
\text { control group (HIIT: pre 55.12 } 4.37 \text {, post } 56.39 \pm \\
\text { 3.50; MICT: pre } 54.65 \pm 4.82 \text {, post } 53.17 \pm 7.32 \text { ). }\end{array}$ & $\begin{array}{l}\text { No adverse events were } \\
\text { reported during any of } \\
\text { the exercise testing or } \\
\text { training sessions. }\end{array}$ & $\begin{array}{l}\text { No participants were lost to follow- } \\
\text { up. All } 18 \text { participants completed } \\
\text { the HIT intervention with an overall } \\
\text { attendance of } 99 \% \text { ( } 429 \text { out of a } \\
\text { possible } 432 \text { sessions). }\end{array}$ & $\begin{array}{l}\text { Twelve weeks of HIIT } \\
\text { may possibly improve } \\
\text { mental health in older } \\
\text { adults compared to a } \\
\text { non-active control. }\end{array}$ \\
\hline $\begin{array}{l}\text { Mitropoulo } \\
\text { s et al., } \\
2018\end{array}$ & \begin{tabular}{|l|} 
Anxiety and \\
depression \\
subcomponent of \\
the EQ-5D-5 L \\
QoL scale
\end{tabular} & $\begin{array}{l}\text { Secondary } \\
\text { outcome. }\end{array}$ & $\begin{array}{l}\text { There were no significant differences between the } \\
\text { groups neither at baseline nor after the completion of } \\
\text { the exercise intervention in anxiety/ depression scores } \\
\text { (HIIT-ACE pre: } 1.7 \pm 0.8 \text {, post: } 1.5 \pm 0.7 \text {. HIIT-CE } \\
\text { pre: } 1.6 \pm 0.7 \text {, post: } 1.2 \pm 0.4 \text {, Con pre: } 1.6 \pm 0.7 \text {, post: } \\
1.9 \pm 1.4 \text { ). }\end{array}$ & $\begin{array}{l}\text { No exercise-related } \\
\text { complications were } \\
\text { reported. }\end{array}$ & $\begin{array}{l}\text { Compliance to the } 12 \text {-week } \\
\text { exercise programme twice weekly } \\
\text { was } 92 \% \text { and } 88 \% \text { for the HIIT- } \\
\text { ACE and HIIT-CE group } \\
\text { respectively, with one drop-out for } \\
\text { each exercise group. }\end{array}$ & $\begin{array}{l}\text { Twelve weeks of HIIT } \\
\text { did not lead to superior } \\
\text { improvements in } \\
\text { anxiety and depression } \\
\text { when compared to a } \\
\text { non-active control in } \\
\text { patients with SSc. }\end{array}$ \\
\hline $\begin{array}{l}\text { Malmo et } \\
\text { al., } 2016\end{array}$ & \begin{tabular}{|l|} 
Mental \\
Component \\
Summary (MCS) \\
of the Short \\
Form-36 QoL \\
scale
\end{tabular} & $\begin{array}{l}\text { Secondary } \\
\text { outcome. }\end{array}$ & $\begin{array}{l}\text { HIIT participants experienced a significant } \\
\text { improvement in mental health scores whereas the } \\
\text { control group did not, however no between-groups } \\
\text { difference was observed (HIIT pre: } 50.6 \pm 8.4 \text {, change } \\
\text { to follow-up: } 3.6 \pm 6.5 \text {, Con pre: } 50.5 \pm 10.8 \text {, change to } \\
\text { follow-up: } 1.4 \pm 7.2 \text { ). }\end{array}$ & $\begin{array}{l}\text { There were no major } \\
\text { adverse events, but } 2 \\
\text { patients experienced } \\
\text { episodes of bursitis that } \\
\text { required them to } \\
\text { substitute bicycle } \\
\text { exercise for treadmill } \\
\text { exercise for a short } \\
\text { period of time. }\end{array}$ & $\begin{array}{l}\text { All patients completed the study } \\
\text { period. As a result of intercurrent } \\
\text { infections and musculoskeletal } \\
\text { symptoms, } 6 \text { patients completed } \\
<80 \%(56 \%-78 \%) \text { of the planned } \\
\text { number of exercises. }\end{array}$ & $\begin{array}{l}\text { Twelve weeks of HIIT } \\
\text { lead to improvements } \\
\text { in mental health in } \\
\text { patients with AF } \\
\text { whereas a non-active } \\
\text { control did not. }\end{array}$ \\
\hline $\begin{array}{l}\text { Conraads et } \\
\text { al., } 2015\end{array}$ & $\begin{array}{l}\text { Mental } \\
\text { Component } \\
\text { Summary (MCS) } \\
\text { of the Short } \\
\text { Form-12 QoL } \\
\text { scale }\end{array}$ & $\begin{array}{l}\text { Secondary } \\
\text { outcome. }\end{array}$ & $\begin{array}{l}\text { Mental wellbeing improved significantly following } \\
\text { both HIIT and ACT, with no group differences (HIIT } \\
\text { pre: } 36.1 \pm 7.8 \text {, post } 38.6 \pm 7.7 \text {, ACT pre: } 35.8 \pm 7.5 \text {, } \\
\text { post: } 38.8 \pm 5.7 \text { ). }\end{array}$ & $\begin{array}{l}\text { No adverse events were } \\
\text { reported during the } \\
\text { training sessions. One } \\
\text { patient (ACT) had an } \\
\text { acute myocardial } \\
\text { infarction, >24 h after } \\
\text { his last training session. } \\
\text { Two other patients } \\
\text { (both ACT) had a } \\
\text { significant ST- } \\
\text { depression during the } \\
\text { exercise test at } 6 \\
\text { weeks. }\end{array}$ & $\begin{array}{l}\text { Twenty-six participants dropped-out } \\
\text { of the intervention (HITT=15, } \\
\text { ACT=11). Compliance for the HIIT } \\
\text { group was } 35.7 \pm 1.1 \text { training } \\
\text { sessions and for the ACT group } 35.6 \\
\pm 1.5 \text { training sessions. }\end{array}$ & $\begin{array}{l}\text { Similar improvements } \\
\text { in mental wellbeing } \\
\text { were seen following } 12 \\
\text { weeks of HIIT and } 12 \\
\text { weeks of ACT in } \\
\text { patients with CAD. }\end{array}$ \\
\hline
\end{tabular}




\begin{tabular}{|c|c|c|c|c|c|c|}
\hline \begin{tabular}{|l|} 
Pattyn et \\
al., $2016(1$ \\
year follow- \\
up \\
of Conraads \\
et al., \\
$2015)$ \\
\end{tabular} & \begin{tabular}{|l|} 
Mental \\
Component \\
Summary (MCS) \\
of the Short \\
Form-12 QoL \\
scale
\end{tabular} & $\begin{array}{l}\text { Secondary } \\
\text { outcome. }\end{array}$ & $\begin{array}{l}\text { Mental wellbeing did not significantly change from } \\
\text { end of intervention to } 1 \text {-year follow-up (HIIT } 12 \\
\text { weeks: } 38.6 \pm 7.6,52 \text { weeks: } 39.4 \pm 7.2 \text {, ACT } 12 \\
\text { weeks: } 38.7 \pm 5.5,52 \text { weeks: } 39.4 \pm 5.8 \text { ). }\end{array}$ & $\begin{array}{l}\text { No adverse events were } \\
\text { reported during the } \\
\text { training sessions. Nine } \\
\text { patients had a CAD } \\
\text { related adverse event } \\
\text { during the follow-up } \\
\text { period ( } 6 \text { AIT, } 3 \text { ACT). }\end{array}$ & $\begin{array}{l}\text { Twenty-six participants dropped-out } \\
\text { of the intervention (HIIT=15, } \\
\text { ACT=11) and a further } 11 \text { were lost } \\
\text { to } 1 \text {-year follow-up (HIIT=5, } \\
\text { ACT=6). }\end{array}$ & $\begin{array}{l}\text { Mental wellbeing } \\
\text { remained stable from } \\
\text { end of HIIT to } 1 \text { year } \\
\text { follow-up in patients } \\
\text { with CAD. }\end{array}$ \\
\hline $\begin{array}{l}\text { Jaureguizar } \\
\text { et al., } 2016\end{array}$ & \begin{tabular}{|l|} 
Mental \\
Component \\
Summary (MCS) \\
of the Short \\
Form-36 QoL \\
scale
\end{tabular} & $\begin{array}{l}\text { Secondary } \\
\text { outcome. }\end{array}$ & $\begin{array}{l}\text { Significant increases in mental health were observed } \\
\text { in the HIIT group (HIIT pre: } 41.0 \pm 12.4 \text {, post: } 49 \pm 11 \text {, } \\
\text { change } 7.8 \pm 14.0, \mathrm{p}<0.01 \text {, MICT pre: } 48 \pm 12 \text {, post: } \\
50 \pm 14 \text { ). }\end{array}$ & $\begin{array}{l}\text { No incidents or } \\
\text { complications were } \\
\text { recorded. }\end{array}$ & $\begin{array}{l}\text { Adherence to the treatment sessions } \\
\text { was } 87.5 \% \text { in the MCT group and } \\
92 \% \text { in the HIIT group. }\end{array}$ & $\begin{array}{l}\text { A greater improvement } \\
\text { in mental wellbeing } \\
\text { was seen following } 8 \\
\text { weeks of HIIT } \\
\text { compared to MICT in } \\
\text { patients with CAD. }\end{array}$ \\
\hline $\begin{array}{l}\text { Karlsen et } \\
\text { al., } 2017\end{array}$ & $\begin{array}{l}\text { Epworth } \\
\text { sleepiness } \\
\text { questionnaire } \\
\text { (ESQ) }\end{array}$ & $\begin{array}{l}\text { Primary } \\
\text { outcome. }\end{array}$ & $\begin{array}{l}\text { The Epworth self-reported sleepiness scale was } \\
\text { significantly improved in the HIIT group compared } \\
\text { with the control group }(\mathrm{p} \leq 0.05) \text { at } 12 \text { weeks }(\mathrm{HIIT} \\
\text { pre: } 10.0 \pm 3.6 \text {, post: } 7.3 \pm 3.7 \text {; Con pre: } 5.9 \pm 4.3 \text {, post: } \\
6.5 \pm 5.0) \text {. }\end{array}$ & $\begin{array}{l}\text { One participant in the } \\
\text { HIIT group experienced } \\
\text { back pain, it is not clear } \\
\text { whether this was } \\
\text { exercise-related. }\end{array}$ & $\begin{array}{l}\text { Two patients in the HIIT group were } \\
\text { lost to follow-up ( } 1 \text { due to back } \\
\text { pain, } 1 \text { lack of time). Subjects in the } \\
\text { HIIT group performed } 21 \pm 3 \\
\text { supervised training sessions ( } 88 \% \\
\text { compliance). }\end{array}$ & $\begin{array}{l}\text { Twelve weeks of HIIT } \\
\text { improved self-reported } \\
\text { sleepiness in subjects } \\
\text { with obese } \\
\text { sleep apnoea compared } \\
\text { to a non-active control. }\end{array}$ \\
\hline $\begin{array}{l}\text { Ellingsen et } \\
\text { al., } 2017\end{array}$ & $\begin{array}{l}\text { Hospital Anxiety } \\
\text { and Depression } \\
\text { Scale } \\
\text { (HADS); Global } \\
\text { Mood Scale } \\
\text { (Positive and } \\
\text { negative affect) }\end{array}$ & $\begin{array}{l}\text { Secondary } \\
\text { outcome. }\end{array}$ & $\begin{array}{l}\text { There were no within-group or between-group } \\
\text { differences in anxiety, depression or global mood at } \\
\text { baseline, } 12 \text { weeks, or } 52 \text { weeks (HADS-A (median): } \\
\text { HIIT: pre: } 4.0 \text { post: } 4.0,52 \text { weeks } 4.0 \text {, MICT: pre: } 4.0 \text {, } \\
\text { post: } 4.0,52 \text { weeks: } 4.0 \text {, RRE: pre: } 5.0 \text {, post: } 4.0,52 \\
\text { weeks: } 4.0 \text {; HADS-D (median): HIIT: pre: } 4.0 \text {, post: } \\
\text { 3.0, } 52 \text { weeks: } 3.0 \text {; MICT: pre: } 4.0 \text {, post: } 3.0,52 \\
\text { weeks: } 4.0 \text {, RRE: pre: } 3.0 \text {, post: } 3.0,52 \text { weeks } 4.0 \text {; } \\
\text { positive affect (median): HIIT: pre: } 21 \text {, post: } 21,52 \\
\text { weeks: } 22 \text {; MICT: pre: } 20 \text {, post: } 23,52 \text { weeks: } 21 \text {, } \\
\text { RRE: pre: } 21 \text {, post: } 22,52 \text { weeks: } 22 \text {;egative affect } \\
\text { (median): HIT: pre: } 12 \text {, post: } 9,52 \text { weeks: } 12 \text {; MICT: } \\
\text { pre: } 12, \text { post: } 10,52 \text { weeks: } 10, \text { RRE: pre: } 12 \text {, post: } 9 \text {, } \\
52 \text { weeks: } 12) \text {. }\end{array}$ & $\begin{array}{l}\text { There were no } \\
\text { significant differences } \\
\text { between groups in } \\
\text { number of SAEs } \\
\text { (HIIT=9, MICT=6, } \\
\text { RRE=5). Three events } \\
\text { occurred within } 3 \text { hours } \\
\text { of exercise in the HIIT } \\
\text { group. One patient had } \\
\text { ventricular arrhythmia } \\
\text { with cardiac arrest and } \\
\text { stopped the exercise } \\
\text { program. Another } \\
\text { patient had } \\
\text { inappropriate } \\
\text { implantable } \\
\text { cardioverter- } \\
\text { defibrillator discharge } \\
\text { unrelated to arrhythmia } \\
\text { during exercise. A third } \\
\text { experienced dizziness. }\end{array}$ & $\begin{array}{l}\text { Nine dropped out because of SAEs, } \\
\text { and } 7 \text { withdrew or were lost to } \\
\text { follow-up. Median adherence to } \\
\text { supervised training was } 35 \text { (34-36) } \\
\text { sessions of } 36 \text { possible in HIIT and } \\
\text { MCT and } 4 \text { (3-4) of } 4 \text { in RRE. }\end{array}$ & $\begin{array}{l}\text { Twelve weeks of HIIT } \\
\text { had no effect on } \\
\text { anxiety, depression, } \\
\text { positive and negative } \\
\text { affect in patients with } \\
\text { HF. }\end{array}$ \\
\hline
\end{tabular}




\begin{tabular}{|c|c|c|c|c|c|c|}
\hline $\begin{array}{l}\text { Lee et al., } \\
2019\end{array}$ & $\begin{array}{l}\text { Centre } \\
\text { for Epidemiologi } \\
\text { cal Studies Depr } \\
\text { ession Scale (CE } \\
\text { S-D) }\end{array}$ & $\begin{array}{l}\text { Secondary } \\
\text { outcome. }\end{array}$ & $\begin{array}{l}\text { Both groups endorsed fewer depressive symptoms } \\
\text { after the programme, with the HIIT group } \\
\text { demonstrating a larger reduction in symptoms } \\
\text { (HIIT: pre } 11.5 \pm 5.6 \text {, post } 9.4 \pm 5.1 \text {, MICT: pre } 13.9 \\
\pm 5.3 \text {, post } 13.0 \pm 7.6 \text { ), though there was not the power } \\
\text { to detect statistical differences between groups. }\end{array}$ & $\begin{array}{l}\text { The patients did not } \\
\text { experience any serious } \\
\text { adverse events } \\
\text { following the exercise } \\
\text { sessions. One woman } \\
\text { had worsening } \\
\text { osteoarthritis in her } \\
\text { knee following HIIT } \\
\text { which was a pre- } \\
\text { existing condition. }\end{array}$ & $\begin{array}{l}59 \% \text { of the women dropped out } \\
\text { from the HIIT group, while } 50 \% \text { of } \\
\text { the women dropped out from the } \\
\text { MICT group. Patients completed } \\
72.2 \% \pm 15.2 \% \text { of the five exercise } \\
\text { sessions prescribed per week in the } \\
\text { MICT group, and the HIIT group } \\
\text { completed } 76.2 \% \pm 13.6 \% \text { of their } 5 \\
\text { weekly exercise sessions (p>0.05). }\end{array}$ & $\begin{array}{l}\text { A } 24 \text { week HIIT regime } \\
\text { may lead to greater } \\
\text { improvements in } \\
\text { depressive symptoms } \\
\text { compared to usual care } \\
\text { in women with CAD. }\end{array}$ \\
\hline $\begin{array}{l}\text { Batrakoulis } \\
\text { et al., } 2019\end{array}$ & $\begin{array}{l}\text { General Health } \\
\text { Questionnaire } \\
\text { (GHQ-12) } \\
\text { (psychological } \\
\text { distress); } \\
\text { subjective } \\
\text { vitality scale } \\
\text { (SVS) } \\
\text { (Eudemonic } \\
\text { well-being) }\end{array}$ & $\begin{array}{l}\text { Primary } \\
\text { outcome. }\end{array}$ & $\begin{array}{l}\text { In control subjects, GHQ-12 remained unaltered. In } \\
\text { HIIT-10month, GHQ-12 score decreased from } \\
\text { baseline to mid- }(-65 \%, p=0.001) \text { and post-training } \\
(-72 \%, p=0.001) \text {. In HIIT-5months + detraining, } \\
\text { GHQ-12 score decreased from baseline to mid- } \\
\text { training }(-71 \%, p=0.001) \text { and remained above pre- } \\
\text { training levels following detraining ( }-33 \% \text {, } \\
p=0.001) \text {. No changes were noted in SVS in control } \\
\text { subjects. In HIIT-10 month, SVS score increased from } \\
\text { baseline to mid- }(+50 \%, p=0.001) \text { and post-training } \\
(+53 \%, p=0.001) . \text { In HIIT-5months }+ \text { detraining, } \\
\text { SVS score increased from baseline to mid-training } \\
(+44 \%, p=0.001) \text { and remained above pre-training } \\
\text { levels following detraining }(+18 \%, p=0.001) \text {. At } \\
\text { post-training, HIIT-10month demonstrated higher } \\
\text { SVS score than HIIT-5months }+ \text { detraining }(+31 \%, \\
p=0.000) \text {. }\end{array}$ & $\begin{array}{l}\text { No injuries or other } \\
\text { exercise-induced health } \\
\text { problems were } \\
\text { recorded. }\end{array}$ & $\begin{array}{l}\text { Training had an } 8 \% \text { and } 94 \% \\
\text { attrition and attendance rates, } \\
\text { respectively. }\end{array}$ & $\begin{array}{l}\text { Five to ten months of } \\
\text { HIIT may improve } \\
\text { psychosocial distress } \\
\text { and subjective vitality } \\
\text { in inactive obese } \\
\text { women compared to a } \\
\text { non-active control. }\end{array}$ \\
\hline $\begin{array}{l}\text { Yardley et } \\
\text { al., } 2017\end{array}$ & \begin{tabular}{|l|} 
Beck's \\
Depression \\
Inventory (BDI); \\
The Hospital \\
Anxiety and \\
Depression Scale \\
(HADS); Mental \\
Component \\
Summary (MCS) \\
of the Short \\
Form-36 QoL \\
scale
\end{tabular} & $\begin{array}{l}\text { Secondary } \\
\text { outcome. }\end{array}$ & $\begin{array}{l}\text { There was no difference in MCS score from baseline } \\
\text { to 5-year follow-up (HIIT: pre: } 53 \pm 11,5 \text {-year: } 51 \pm 14 \text {, } \\
(-1.9 \text { [95\% CI: }-3.7-(-0.5)] \text {, Control: pre: } 51 \pm 8,5 \text { - } \\
\text { year: } 48 \pm 12(-1.7 \text { [95\%CI: }-6.0-2.6]) \text {. At the 5-year } \\
\text { follow-up, there was no significant difference between } \\
\text { the groups for depression. Anxiety decreased in the } \\
\text { HIT group and increased in the control group with a } \\
\text { significant difference at the } 5 \text {-year follow-up (HIIT } \\
\text { mean change:-0.7 [95\%CI: }-1.5-0.1] \text {, control mean } \\
\text { change: } 1.2[95 \% \text { CI:-0.0-2.5]. When the cut-off } \\
\text { values of anxiety (>7) were applied, the frequency of } \\
\text { anxiety between the two groups showed no significant } \\
\text { differences, but there was a trend toward a higher } \\
\text { percentage of patients with anxiety in the control } \\
\text { group (28\%) compared with the HIT group }(21 \%) \text {. }\end{array}$ & $\begin{array}{l}\text { There were no serious } \\
\text { exercise related adverse } \\
\text { events. }\end{array}$ & $\begin{array}{l}\text { Forty-one patients were available at } \\
\text { 5-year follow-up. }\end{array}$ & $\begin{array}{l}\text { HIIT may reduce the } \\
\text { burden of anxiety } \\
\text { in HTx recipients. }\end{array}$ \\
\hline
\end{tabular}




\begin{tabular}{|c|c|c|c|c|c|c|}
\hline \begin{tabular}{|l} 
Leahy et \\
al., 2018
\end{tabular} & \begin{tabular}{|l|} 
Strengths and \\
Difficulties \\
Questionnaire \\
(SDQ) \\
(psychological \\
distress); \\
Perceived Stress \\
Scale
\end{tabular} & $\begin{array}{l}\text { Secondary } \\
\text { outcome. }\end{array}$ & $\begin{array}{l}\text { There was a moderate group-by-time interaction for } \\
\text { the total psychological difficulties score }[-2.1 \text { units } \\
(95 \% \mathrm{CI},-4.0 \text { to }-0.3), \mathrm{P}=0.023, \mathrm{~d}=0.57] \text {. Analysis } \\
\text { revealed significant reductions in 'emotional } \\
\text { problems' }[-0.9 \text { units ( } 95 \% \mathrm{CI},-1.6 \text { to }-0.01) \text {, } \\
\mathrm{P}=0.022, \mathrm{~d}=0.61] \text { and 'peer problems' subscales [-0.7 } \\
\text { units }(95 \% \mathrm{CI},-1.3 \text { to }-0.1), \mathrm{P}=0.017, \mathrm{~d}=0.60] \text {. There } \\
\text { were no group-by-time effects for perceived stress [- } \\
0.1 \text { ( } 95 \% \mathrm{CI},-0.3 \text { to } 0.09), \mathrm{P}=0.253, \mathrm{~d}=0.26] \text {. }\end{array}$ & $\begin{array}{l}\text { No exercise related } \\
\text { adverse events were } \\
\text { observed. }\end{array}$ & $\begin{array}{l}84 \% \text { of the intervention participants } \\
\text { and } 97 \% \text { of the control participants } \\
\text { were retained at follow up. } \\
\text { Participants averaged } 1.7(0.3) \\
\text { sessions/week over the study } \\
\text { period. }\end{array}$ & $\begin{array}{l}14 \text { weeks of HIT may } \\
\text { possibly psychological } \\
\text { distress in adolescents, } \\
\text { although it did not } \\
\text { impact perceived } \\
\text { stress. }\end{array}$ \\
\hline \begin{tabular}{|l} 
Stavrinou e \\
al., 2018
\end{tabular} & $\begin{array}{l}\text { Mental } \\
\text { Component } \\
\text { Summary (MCS) } \\
\text { of the Short } \\
\text { Form-36 QoL } \\
\text { scale }\end{array}$ & $\begin{array}{l}\text { Secondary } \\
\text { outcome. }\end{array}$ & $\begin{array}{l}\text { Mental wellbeing was significantly elevated in both } \\
\text { HIIT-2 }(7.3,90 \% \mathrm{CI}=-0.3 \text { to } 14.0, \mathrm{p}=0.003 \text {, Cohen's } \\
d=0.54) \text { and HIIT-3 }(8.9,90 \% \mathrm{CI}=3.0 \text { to } 14.8, \\
p=0.001 \text {, Cohen's } d=0.69) \text { compared with baseline. } \\
\text { However, this improvement was significantly higher } \\
\text { compared with the control group only for HIIT- } 3 \\
(p=0.045 \text {, Cohen's } d=0.64) \text { but not for HIIT- } 2 \\
(p=0.17, \text { Cohen's } d=0.38) .\end{array}$ & $\begin{array}{l}\text { No adverse events or } \\
\text { musculoskeletal injuries } \\
\text { were reported. }\end{array}$ & $\begin{array}{l}\text { No participants withdrew from the } \\
\text { study and adherence was } 97.8 \% \text { in } \\
\text { both HIIT groups. }\end{array}$ & $\begin{array}{l}8 \text { weeks of HIIT, } \\
\text { performed thrice } \\
\text { weekly, may improve } \\
\text { mental wellbeing in } \\
\text { inactive adults } \\
\text { compared to a non- } \\
\text { active control. }\end{array}$ \\
\hline $\begin{array}{l}\text { Jimenez- } \\
\text { Garcia et } \\
\text { al., } 2019\end{array}$ & $\begin{array}{l}\text { Mental } \\
\text { Component } \\
\text { Summary (MCS) } \\
\text { of the Short } \\
\text { Form-36 QoL } \\
\text { scale }\end{array}$ & $\begin{array}{l}\text { Secondary } \\
\text { outcome. }\end{array}$ & $\begin{array}{l}\text { The analysis of MCS showed a significant main effect } \\
\text { for the variable time, } F(1,69)=5.19, p=.026, \eta 2=.07 \text {, } \\
\text { but no significant effect was seen for the variable } \\
\text { group x time (Con pre: } 71.19 \pm 24.40 \text {, post: } 69.91 \pm \\
\text { 19.67; MIIT pre: } 66.90 \pm 21.76 \text {, post: } 75.13 \pm 15.11 \text {; } \\
\text { HIIT: pre: } 68.60 \pm 22.97 \text {, post: } 77.73 \pm 18.44, p>.05 \text { ). }\end{array}$ & $\begin{array}{l}\text { The methodology } \\
\text { highlights that injuries } \\
\text { were reported but no } \\
\text { injuries were noted with } \\
\text { the trial results. }\end{array}$ & $\begin{array}{l}\text { A total of } 26 \text { completed HIIT, } 24 \\
\text { completed MIIT and } 23 \text { completed } \\
\text { the control program. Subjects } \\
\text { showed high adherence to the } \\
\text { exercise training programs, } \\
\text { participating in at least } 83.33 \% \text { of } \\
\text { the sessions. }\end{array}$ & $\begin{array}{l}12 \text { weeks of HIIT did } \\
\text { not significantly } \\
\text { improve mental } \\
\text { wellbeing in older } \\
\text { adults compared to } \\
\text { MIIT and a non-active } \\
\text { control, but significant } \\
\text { pre-post improvements } \\
\text { were seen. }\end{array}$ \\
\hline $\begin{array}{l}\text { Cheema et } \\
\text { al., } 2015\end{array}$ & \begin{tabular}{|l|} 
Mental \\
Component \\
Summary (MCS) \\
of the Short \\
Form-36 QoL \\
scale
\end{tabular} & $\begin{array}{l}\text { Secondary } \\
\text { outcome. }\end{array}$ & $\begin{array}{l}\text { Mental wellbeing scores increased by } 9.6 \% \text { in the } \\
\text { boxing group and decreased by } 4.1 \% \text { in the walking } \\
\text { group (boxing pre: } 45.01 \pm 7.73 \text {, post } 49.31 \pm 11.40, \% \\
\text { change: } 9.64 \pm 21.46 \text {; walking pre: } 50.93 \pm 8.71 \text {, post: } \\
49.12 \pm 11.34, \% \text { change }-4.10 \pm 12.80 \text { ). }\end{array}$ & $\begin{array}{l}\text { Two participants in the } \\
\text { HIIT group experienced } \\
\text { an adverse event which } \\
\text { may have been due to } \\
\text { the intervention. One } \\
\text { participant experienced } \\
\text { tennis elbow so } \\
\text { substituted kicking and } \\
\text { elbow striking in place } \\
\text { of punching. One } \\
\text { participant experienced } \\
\text { a strain of the } \\
\text { gastrocnemius muscle } \\
\text { and substituted rowing } \\
\text { for skipping. } \\
\end{array}$ & \begin{tabular}{|l|} 
Two female participants in the \\
walking group withdrew: one due to \\
a pre-existing knee injury requiring \\
surgery (week 2) and one for \\
personal reasons (week 5). \\
Adherence to training was $79 \pm 15 \%$ \\
and $55 \pm 43 \%$ in the boxing and \\
walking groups, respectively.
\end{tabular} & $\begin{array}{l}\text { Boxing HIT may } \\
\text { improve mental } \\
\text { wellbeing in adults } \\
\text { with abdominal } \\
\text { obesity, a large trial is } \\
\text { needed. }\end{array}$ \\
\hline $\begin{array}{l}\text { Koufaki et } \\
\text { al., } 2014\end{array}$ & $\begin{array}{l}\text { Mental } \\
\text { Component } \\
\text { Summary (MCS) } \\
\text { of the Short }\end{array}$ & $\begin{array}{l}\text { Secondary } \\
\text { outcome. }\end{array}$ & $\begin{array}{l}\text { No significant group } \times \text { time interactions were } \\
\text { observed for the mental health subscale score (MICT } \\
\text { pre: } 75.3 \pm 18.9,12 \text { weeks: } 76.5 \pm 17.8 \text {, post: } 68.5 \pm\end{array}$ & $\begin{array}{l}\text { There was one episode } \\
\text { of syncope during } \\
\text { exercise (HIT) and one } \\
\text { anxiety/panic attack }\end{array}$ & $\begin{array}{l}\text { Originally } 16 \text { patients were allocated } \\
\text { to HIIT and } 17 \text { to MICT, } 8 \text { HIIT } \\
\text { patients and } 9 \text { MICT patients were } \\
\text { included in the final analysis, the }\end{array}$ & $\begin{array}{l}24 \text { weeks of HIT did } \\
\text { not improve mental } \\
\text { wellbeing in patients } \\
\text { with chronic HF. }\end{array}$ \\
\hline
\end{tabular}




\begin{tabular}{|c|c|c|c|c|c|c|}
\hline & $\begin{array}{l}\text { Form-36 QoL } \\
\text { scale }\end{array}$ & & $\begin{array}{l}24.3 \text {; HIIT pre: } 67.3 \pm 20.5,12 \text { weeks: } 70.6 \pm 18.4 \\
\text { post: } 65.2 \pm 12.9)\end{array}$ & $\begin{array}{l}\text { (CAT). Two patients } \\
\text { (CAT) could not } \\
\text { tolerate the exercise } \\
\text { prescription due to } \\
\text { severe orthopedic pain. }\end{array}$ & $\begin{array}{l}\text { others were lost to follow-up due to } \\
\text { medical reasons or loss of interest. } \\
\text { Every patient had accumulated at } \\
\text { least } 85 \% \text { of planned sessions. }\end{array}$ & \\
\hline $\begin{array}{l}\text { Svensson et } \\
\text { al., } 2017\end{array}$ & $\begin{array}{l}\text { Mental } \\
\text { Component } \\
\text { Summary (MCS) } \\
\text { of the Short } \\
\text { Form-36 QoL } \\
\text { scale }\end{array}$ & $\begin{array}{l}\text { Primary } \\
\text { outcome. }\end{array}$ & $\begin{array}{l}\text { The MCS mean score increased significantly ( } \mathrm{p}< \\
\text { 0.01) for the HIIT group but not for MIT nor control } \\
\text { (HIIT pre: } 49.7 \pm 12.5 \text {, post: } 53.4 \pm 9.6 \text {, MIT pre: } 53.1 \pm \\
\text { 8.7, post: } 52.7 \pm 11.6 \text {, Control pre: } 48.6 \pm 9.6 \text {, post: } \\
50.2 \pm 13.9 \text { ). }\end{array}$ & $\begin{array}{l}\text { Adverse events not } \\
\text { reported. }\end{array}$ & $\begin{array}{l}\text { Dropout rates were } 31 \% \text { in the } \\
\text { control group, } 36 \% \text { in the HIIT and } \\
42 \% \text { in the MIT groups. Reasons } \\
\text { included medical reasons }(n=18), \\
\text { work commitments }(n=12), \text { lack of } \\
\text { time ( } n=12) \text {, personal reasons }(n=12 \\
\text { participants) or no stated reason } \\
(n=12) \text {. }\end{array}$ & \begin{tabular}{|l|}
16 weeks of HIIT led to \\
improvements in \\
mental wellbeing in \\
obese participants \\
whereas MIT and \\
control did not.
\end{tabular} \\
\hline \begin{tabular}{|l|} 
Tew et al., \\
2017
\end{tabular} & \begin{tabular}{l|} 
Mental \\
Component \\
Summary (MCS) \\
of the Short \\
Form-36 QoL \\
scale
\end{tabular} & $\begin{array}{l}\text { Secondary } \\
\text { outcome. }\end{array}$ & $\begin{array}{l}\text { HIIT had no effect on the total MCS score (HIIT pre: } \\
57 \pm 6 \text {, post: } 54.6 \text {, Con pre: } 53 \pm 10 \text {, post: } 55.1 \\
\text { [difference }-0 \cdot 5,-3 \cdot 3 \text { to } 2 \cdot 3 \text { ] }, 12 \text { week follow-up } \\
\text { HIIT: } 55 \cdot 6 \text {, Con: } 55.0 \text { [difference } 0 \cdot 6,-2 \cdot 4 \text { to } \\
3 \cdot 6] \text { ). }\end{array}$ & $\begin{array}{l}\text { One participant reported } \\
\text { feeling unwell } \\
\text { approximately } 8 \mathrm{~h} \text { after } \\
\text { the exercise session; } \\
\text { subsequent cardiology } \\
\text { assessment showed no } \\
\text { abnormality, but the } \\
\text { subject withdrew from } \\
\text { the study. One non- } \\
\text { serious adverse event } \\
\text { was reported following } \\
\text { HIIT: short-lived } \\
\text { angina. } \\
\end{array}$ & $\begin{array}{l}\text { The retention rate was } 91 \% \text {. Five of } \\
53 \text { participants formally left the } \\
\text { study ( } 3 \text { HIIT, } 2 \text { control), } 3 \\
\text { withdrew as they were no longer } \\
\text { undergoing surgery and } 1 \text { had } \\
\text { surgery expediated. One HIIT } \\
\text { participant withdrew after } \\
\text { completing just one exercise session } \\
\text { and feeling unwell. Overall } \\
\text { attendance rate was } 76 \% \text {. }\end{array}$ & $\begin{array}{l}4 \text { weeks of HIIT had no } \\
\text { effect on the mental } \\
\text { wellbeing of patients } \\
\text { awaiting AAA repair. }\end{array}$ \\
\hline $\begin{array}{l}\text { Stensvold et } \\
\text { al., } 2010\end{array}$ & $\begin{array}{l}\text { Mental } \\
\text { Component } \\
\text { Summary (MCS) } \\
\text { of the Short } \\
\text { Form-36 QoL } \\
\text { scale }\end{array}$ & $\begin{array}{l}\text { Secondary } \\
\text { outcome. }\end{array}$ & $\begin{array}{l}\text { There was a larger increase in MCS following HIIT } \\
\text { and ST compared to non-active control (HIIT pre: } \\
\text { 67.77, post } 76.04 \text {; ST pre: } 70.94 \text {, post: } 83.72 \text {; Control } \\
\text { pre: } 82.28 \text {, post: } 81.66 \text { ). }\end{array}$ & $\begin{array}{l}\text { No major complications } \\
\text { or cardiac events } \\
\text { occurred during the } \\
\text { study period. }\end{array}$ & $\begin{array}{l}\text { Participants were required to } \\
\text { complete at least } 80 \% \text { of the } \\
\text { exercise sessions. One person from } \\
\text { the ST group and one person from } \\
\text { the control group refused to } \\
\text { complete the training. }\end{array}$ & $\begin{array}{l}12 \text { weeks of HIIT or ST } \\
\text { may improve mental } \\
\text { wellbeing in people } \\
\text { with MetS, more } \\
\text { research is needed. }\end{array}$ \\
\hline $\begin{array}{l}\text { Lunt et al., } \\
2014\end{array}$ & $\begin{array}{l}\text { Mental Health } \\
\text { subdomain of } \\
\text { the Short Form- } \\
36 \text { QoL scale }\end{array}$ & $\begin{array}{l}\text { Secondary } \\
\text { outcome. }\end{array}$ & $\begin{array}{l}\text { MCS score marginally increased following HIT and } \\
\text { MVIT but not following WALK (HIT: pre } 71.94 \pm \\
\text { 14.73, post 76.73 } 15.38 \text {; MVIT: pre } 73.75 \pm 11.02 \\
\text { post } 77.25 \pm 14.72 \text {; WALK: pre } 75.65 \pm 14.84 \text { post } \\
76.47 \pm 11.32 \text { ). }\end{array}$ & $\begin{array}{l}\text { Eight exercise related } \\
\text { adverse events were } \\
\text { reported (WALK: } 1 \\
\text { Shin splints; AIT: } 2 \\
\text { Ankle sprain, 1 Calf } \\
\text { strain; MVIT: 1 } \\
\text { Iliotibial band } \\
\text { syndrome, 1 Achilles } \\
\text { tendonitis, 1 Bilateral } \\
\text { flexor tendinitis, } 1 \\
\text { Plantar fasciitis). }\end{array}$ & $\begin{array}{l}\text { Attendance at sessions was } 75 \%, \\
59 \% \text { and } 75 \% \text { in WALK, AIT and } \\
\text { MVIT groups respectively. } 32 \\
\text { participants completed }>70 \% \text { of } \\
\text { their exercise prescription (WALK } \\
n=14 ; \text { AIT } n=9 ; \text { MVIT } n=9 \text { ). }\end{array}$ & \begin{tabular}{|l|} 
Twelve weeks of \\
interval training had no \\
effect on mental \\
wellbeing compared to \\
an active control in a \\
feasibility trial with \\
overweight inactive \\
adults.
\end{tabular} \\
\hline
\end{tabular}

Key terms: $\mathrm{BMI}=$ Body mass index; $\mathrm{CA}=$ continuous aerobic training; Con = control; HIT = high intensity interval training, $\mathrm{HTx}=$ heart transplant recipients; $\mathrm{MD}=$ mean difference; $\mathrm{MICT}=$ moderate intensity continuous training; $\mathrm{SIT}=$ sprint interval training; $\mathrm{QoL}=$ quality of life; $\mathrm{RCT}=$ randomised controlled trial 
Table Three- Random effects meta-analyses for RCTs comparing HIIT with active and non-active control conditions, and measures of heterogeneity

\begin{tabular}{|c|c|c|c|c|c|c|c|c|c|c|c|c|c|}
\hline \multirow[t]{2}{*}{ Analysis } & \multicolumn{5}{|c|}{$\begin{array}{l}\text { Number Meta-analysis } \\
\text { of }\end{array}$} & \multicolumn{2}{|c|}{ Heterogeneity } & \multicolumn{3}{|c|}{ Egger's Intercept } & \multicolumn{2}{|c|}{$\begin{array}{l}\text { Begg and Mazumdar } \\
\text { rank correlation }\end{array}$} & \multirow{2}{*}{\begin{tabular}{|l}
$\begin{array}{l}\text { Duval and Tweedie trim } \\
\text { and fill }\end{array}$ \\
$\begin{array}{l}\text { SMD [95\%CI] (adjusted } \\
\text { studies) }\end{array}$
\end{tabular}} \\
\hline & & $\begin{array}{l}\text { Point } \\
\text { estimate of } \\
\text { effect sizes } \\
\text { (SMD) }\end{array}$ & $\begin{array}{l}95 \% \text { CI } \\
\text { f lower } \\
\text { s boundary }\end{array}$ & $\begin{array}{l}95 \% \mathrm{CI} \\
\text { upper } \\
\text { boundary }\end{array}$ & $\begin{array}{l}\text { P value } \\
\text { (two-tailed) }\end{array}$ & $\mathrm{I}^{2}(\%)$ & Q-value & Intercept & t-value & $\begin{array}{l}\text { P value } \\
\text { (two-tailed) }\end{array}$ & Tau & $\begin{array}{l}\text { P value } \\
\text { (two-tailed) }\end{array}$ & \\
\hline HIIT vs Active Controls : MCS & 10 & 0.272 & 0.088 & 0.456 & 0.004 & 0 & 4.607 & -0.838 & 1.098 & 0.304 & -0.222 & 0.371 & Unchanged \\
\hline HIIT vs Non-Active Controls : MCS & 11 & 0.427 & 0.124 & 0.730 & 0.006 & 61.064 & 25.683 & 3.962 & 1.540 & 0.158 & 0.218 & 0.350 & Unchanged \\
\hline HIIT vs Active Controls: Depression & 9 & -0.110 & -0.310 & 0.091 & 0.284 & 0 & 7.175 & -0.122 & 0.093 & 0.929 & -0.139 & 0.602 & $0.165[-0.359 ; 0.030](2)$ \\
\hline HIIT vs Non-Active Controls : Depression & 10 & -0.496 & -0.973 & -0.020 & 0.041 & 82.138 & 50.389 & -0.034 & 0.010 & 0.993 & -0.089 & 0.721 & $-0.675[-1.132 ;-0.219](2)$ \\
\hline HIIT vs Active Controls : Anxiety & 7 & -0.289 & -0.700 & 0.121 & 0.170 & 67.28 & 44.300 & -0.201 & 1.020 & 0.401 & -0.034 & 0.389 & Unchanged \\
\hline HIIT vs Non-Active Controls : Anxiety & 8 & -0.302 & -0.732 & 0.128 & 0.169 & 71.922 & 24.930 & -2.953 & 1.035 & 0.341 & -0.250 & 0.386 & $-0.427[-0.881 ; 0.027](1)$ \\
\hline HIIT vs Non-Active Controls : Stress & 4 & -0.474 & -0.796 & -0.152 & 0.004 & 20.432 & 3.770 & 4.051 & 1.407 & 0.295 & 0.500 & 0.308 & Unchanged \\
\hline
\end{tabular}

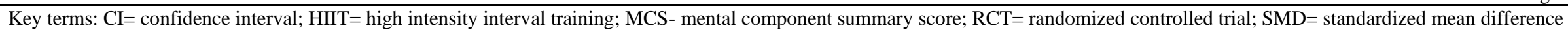

Table Four- Subgroup analysis based on HIIT modality, HIIT intervention duration and length, and population character

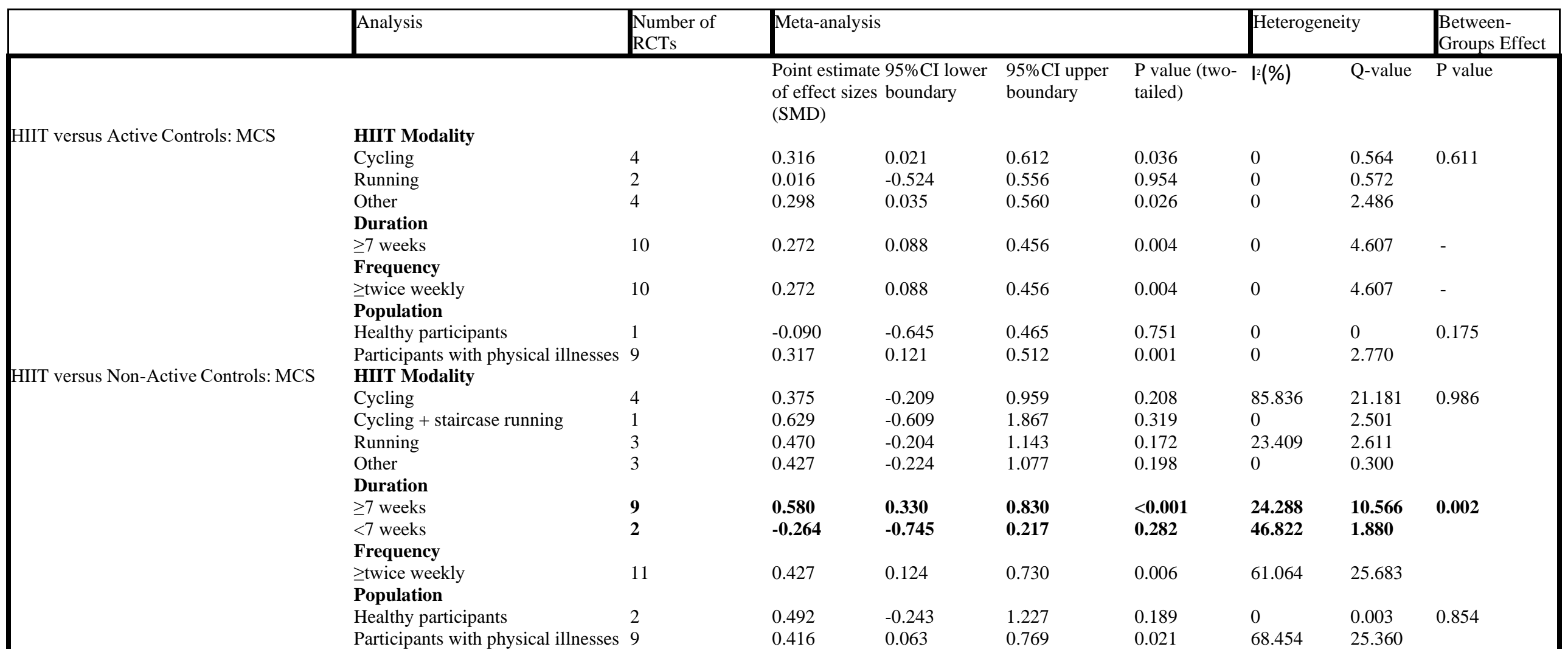


HIIT versus Active Controls: Depression

HIIT versus Non-

Active Controls: Depression

HIIT versus Active Controls: Anxiety

HIIT versus Non-Active Controls: Anxiety

\section{HIIT Modality}

Cycling

Other

Duration

$\geq 7$ weeks

$<7$ weeks

Frequency

$\geq$ twice weekly

<twice weekly

Duration + Frequency

$\geq$ twice weekly and $\geq 7$ weeks

$<$ twice weekly and/or $<7$ weeks

Population

Healthy participants

Participant HIIT Modality

Cycling

Cycling + staircase running

Treadmill walking or running

Duration

$\geq 7$ weeks

$<7$ weeks

Frequency

$\geq$ twice weekly

$<$ twice weekly

Duration + Frequency

$>$ twice weekly and $>7$ weeks

$<$ twice weekly and/or < 7 weeks

Population

Healthy participants

Participants with physical illnesses 7

\section{HIIT Modality}

Cycling

Other

Duration

$\geq 7$ weeks

$<7$ weeks

Frequency

$\geq$ twice weekly

$<$ twice weekly

Duration + Frequency

$\geq$ twice weekly and $\geq 7$ weeks

$<$ twice weekly and/or $<7$ weeks 4

Population

Participants with physical illnesses 7

\section{HIIT Modality}

Cycling

Other

Duration

\begin{tabular}{|c|c|c|c|c|c|c|}
\hline-0.015 & -0.271 & 0.242 & 0.910 & 0 & 2.576 & 0.246 \\
\hline-0.258 & -0.578 & 0.063 & 0.115 & 38.544 & 3.254 & \\
\hline-0.106 & -0.344 & 0.132 & 0.383 & 9.945 & 6.663 & 0.948 \\
\hline-0.121 & -0.515 & 0.272 & 0.546 & 0 & 0.509 & \\
\hline-0.084 & -0.311 & 0.144 & 0.471 & 0 & 0.713 & 0.640 \\
\hline-0.198 & -0.619 & 0.223 & 0.357 & 67.967 & 6.244 & \\
\hline-0.065 & -0.347 & 0.217 & 0.653 & 0 & 0.154 & 0.658 \\
\hline-0.155 & -0.439 & 0.129 & 0.285 & 41.398 & 6.826 & \\
\hline-0.005 & -0.873 & 0.863 & 0.991 & 0 & 1.281 & 0.808 \\
\hline-0.116 & -0.324 & 0.092 & 0.275 & 1.628 & 7.116 & \\
\hline-0.485 & -1.086 & 0.117 & 0.114 & 85.720 & 49.018 & 0.904 \\
\hline-0.824 & -2.566 & 0.918 & 0.354 & 0 & 0 & \\
\hline-0.284 & -1.918 & 1.351 & 0.734 & 0 & 0 & \\
\hline-0.319 & -0.831 & 0.194 & 0.223 & 69.973 & 23.312 & 0.137 \\
\hline-1.169 & -2.164 & -0.173 & 0.021 & 94.140 & 17.065 & \\
\hline-0.545 & -1.058 & -0.033 & 0.037 & 83.657 & 48.951 & 0.536 \\
\hline-0.011 & -1.622 & 1.599 & 0.989 & 0 & 0 & \\
\hline-0.359 & -0.933 & 0.215 & 0.221 & 73.543 & 22.678 & 0.391 \\
\hline-0.817 & -1.692 & 0.059 & 0.067 & 91.097 & 22.463 & \\
\hline-0.673 & -1.582 & 0.237 & 0.147 & 93.095 & 28.964 & 0.649 \\
\hline-0.420 & -1.016 & 0.176 & 0.167 & 69.752 & 19.836 & \\
\hline-0.289 & -0.700 & 0.121 & 0.270 & 67.280 & 44.300 & 0.563 \\
\hline-0.212 & -0.654 & 0.234 & 0.330 & 25.220 & 12.200 & \\
\hline-0.389 & -0.650 & 0.090 & 0.070 & 47.280 & 24.300 & 0.110 \\
\hline-0.212 & -0.654 & 0.234 & 0.330 & 25.220 & 7.400 & \\
\hline-0.501 & -0.891 & 0.221 & 0.200 & 57.820 & 16.300 & 0.340 \\
\hline-0.320 & -0.608 & 0.334 & 0.390 & 56.880 & 9.400 & \\
\hline-0.389 & -0.812 & 0.321 & 0.380 & 55.440 & 12.300 & 0.890 \\
\hline-0.112 & -0.454 & 0.255 & 0.400 & 30.210 & 4.400 & \\
\hline-0.289 & -0.700 & 0.121 & 0.170 & 71.922 & 44.300 & - \\
\hline-0.250 & -0.783 & 0.283 & 0.358 & 74.152 & 19.343 & 0.698 \\
\hline-0.449 & -1.301 & 0.403 & 0.302 & 70.515 & 3.392 & \\
\hline
\end{tabular}

0.246

.948

640

.658

808

904

137

.536

391

649

563

110

.340

890

698 


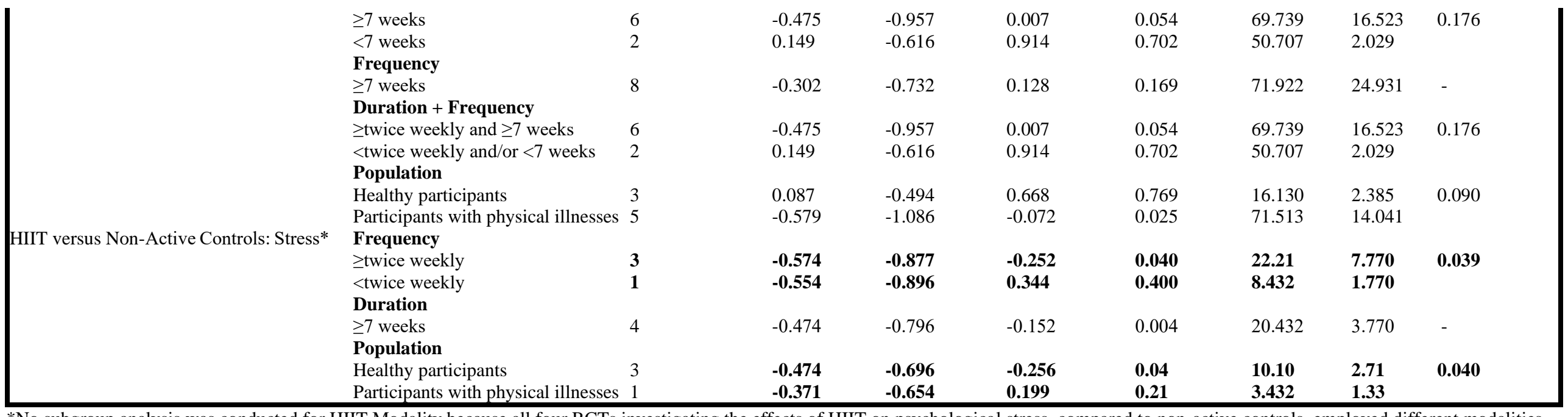

*No subgroup analysis was conducted for HIIT Modality because all four RCTs investigating the effects of HIIT on psychological stress, compared to non-active controls, employed different modalities, thus no meaningful split could be carried out.

Key terms: $\mathrm{CI}=$ confidence interval; $\mathrm{HIIT}=$ high intensity interval training; MCS- mental component summary score; $\mathrm{RCT}=$ randomized controlled trial; SMD= standardized mean difference 